\title{
Register of New Fruit and Nut Cultivars List 45
}

\author{
John R. Clark, Co-editor \\ Department of Horticulture, Plant Science 316 \\ University of Arkansas \\ Fayetteville, AR 72701 \\ Chad E. Finn, Co-editor \\ Horticultural Crops Research Laboratory \\ U.S. Department of Agriculture-Agricultural Research Service \\ 3420 NW Orchard Avenue \\ Corvallis, OR 97330
}

\begin{abstract}
Crop Listings ${ }^{z}$ : Almond Rootstock, Apple, Apricot and Apricot Hybrids, Banana, Blackberry, Blueberry, Cacao, Citrus, Citrus Rootstock, Cranberry, Genip (Quenepa, Spanish Lime), Grape, Grape rootstock, Macadamia, Mango, Nectarine, Passion Fruit, Peach, Peach Rootstock, Pecan, Persian Walnut, Persian Walnut Rootstock, Pineapple, Pistachio, Pitanga (Surinam Cherry), Plantain, Plum and Plum Hybrids, Plum Rootstock, Raspberry, Strawberry
\end{abstract}

\section{ALMOND ROOTSTOCK}

Thomas G. Beckman, USDA-ARS Southeastern Fruit and Tree Nut Research Laboratory, Byron, GA

Greenpac: Compatible with almond cultivar. Described under Peach Rootstock.

\section{APPLE}

James J. Luby and David S. Bedford, Department of Horticultural Science, University of Minnesota, St. Paul, MN

Apple sports are listed and described only in reference to the original apple cultivar. Please see the plant patent or other source of information for more detailed information on sports.

AB17. Bicolor apple similar to Gala but larger and less acidic with purple petals. Origin: Nevis Fruit Co. Ltd., Central Otago, New Zealand by J. McLaren. Kidds D-8 x O.P.; USPP 20,016; 26 May 2009. Fruit: round; conical; blocky appearance; medium-large, $86 \mathrm{~mm}$ diameter; mottled red blush overcolor and green-yellow ground color; medium-white lenticels; flesh white; medium firmness but melting; mildly sub-acid, delicate slightly aromatic flavor; ripens early midseason; moderate storage life. Tree: moderate vigor; spreading, open habit; $45-90^{\circ}$ crotch angles; annual bearing.

\footnotetext{
Very special thanks to Sandra M. Sleezer, Program Technician I, Department of Horticulture, University of Arkansas, for her exceptional work in compiling, editing, researching, and other contributions in the preparation of List 45.

Very special thanks to David Karp, Associate in the Agricultural Experiment Station, University of California, Riverside, for his exceptional work in enlisting contributors for tropical fruits and compiling, editing, and researching submissions for this crop area for List 45 .

${ }^{z}$ Special thanks to the crop contributors for compiling this information. Individuals with cultivars to describe should contact the crop editors directly. DISCLAIMER OF LIABILITY AND ACCURACY: This information is provided as a courtesy of the American Society for Horticultural Science (ASHS) and is presented with the explicit understanding that ASHS and its authors are not rendering any professional service or advice. While ASHS does its best to present current, accurate, and complete information, the information provided herein may be changed at any time by its owners, or become outdated. Readers are encouraged to inquire further for confirmation of all information on cultivar description and intellectual property protection. ASHS strictly disclaims the accuracy or completeness of the information contained herein. ASHS and its authors strictly disclaim any liability whatsoever, direct or indirect, for any damages of any kind resulting from the use of this material.
}

Alvina. Solid red whole tree mutation of Gala. Origin: Drouin, Victoria, Australia by G.E. Fankhauser. Selected 2000; USPP 19,604; 30 Dec. 2008.

B. Thome McIntosh. Early coloring sport of Starling differing from other McIntosh cultivars in greenish flesh coloration and red coloration of blossom and leaf petiole. Origin: Comstock Park, MI, by B.J. Thome. selected 1999; USPP 19,891; 7 Apr. 2009.

Banning Red Fuji. Red sport of Desert Rose Fuji. Origin: East Wenatchee, WA, by B.L. Banning. selected 1999; USPP 16,624; 6 June 2006.

Beller. Attractively colored, late-season apple. Origin: Malott, WA by R. Beller. Chance seedling selected in 1981; USPP 20,057; 2 June 2009. Fruit: round, symmetrical with no ribbing or lobes; medium, diameter 75-85 mm, height 70-75 mm; bicolor type with $50-80 \%$ dark purple red stripes and blush over yellow ground color; not prone to russet or cracking; flesh light cream, medium firmness, fine texture; sweet with little aroma; ripens late-season; stores 3-4 mo. Tree: medium vigor; upright to upright-spreading habit; $30-60^{\circ}$ crotch angles; midseason bloom time.

Brak (Kiku ${ }^{\circledR}$ ). Red sport of Fuji. Origin: South Tyrol, Italy by A. Braun. USPP 15,261; 26 Oct. 2004.

Burkitt Gala. Redder, earlier sport of Tenroy Gala. Origin: Pakowhai, New Zealand by M.E. Burkitt. selected 1993; USPP 17,013; 15 Aug. 2006.

CABp Fuji. Red sport of Nagafu-6 Fuji. Origin: Totara Grove Orchard, New Zealand, by C. Lee, B. Edwards, and A. Delugar. selected 1994; USPP 17,914; 14 Aug. 2007.

Candy. Red sport of Aztec Fuji. Origin: Upper Moutere, Nelson, New Zealand by D. Austin. USPP 18,661; 25 Mar. 2008.

CIVG198 (Modi $^{\circledR}$ ). Deep, red skin color, high sugar content, very firm flesh apple, with scab resistance, long storage capacity and long shelf life. Origin: S. Guiseppe di Comacchio (Ferrara), Italy by M. Leis, A. Martinelli, G. Castagnoli, and F. Tagliani. Gala x Liberty; selected in 1996; EU PVR No. 2005/0312; 21 Feb. 2005. Fruit: conic; $75 \mathrm{~mm}$ diameter, $75 \mathrm{~mm}$ height; $85-95 \%$ deep red overcolor and greyed-yellow ground color; very firm and crisp; medium aroma, slightly acidic; juicy; resistant to bruising, stores for 7 mo. Tree: 
medium vigor; upright habit; $70^{\circ}$ crotch angles; early and annual bearing; resistant to scab (Venturia inaequalis).

CJ07. Early, solid red, whole-tree mutation of Sciearly. Origin: Hawkes Bay, New Zealand by P. Collinge. Selected in 1996; USPP 18,592; 11 Mar. 2008.

Co-op 31 (WineCrisp ${ }^{\mathrm{TM}}$ ). Disease resistant, late-ripening apple, with full, fruity, sweet, mild-subacid flavor. Origin: University of Illinois, Urbana, IL by S.S. Korban, J.C. Goffreda, and J. Janick. Rock 41-12 x PRI 841-103; USPP 20,437; 20 Oct. 2009. Fruit: round, oblong; medium, 60-65 $\mathrm{mm}$ diameter, 60-63 $\mathrm{mm}$ height; $100 \%$ greyed-purple over green-yellow undercolor; flesh yellow, crispy, juicy, and firm; full favored, fruity, sweet, mild-subacid; stores up to $7 \mathrm{mo}$; good for fresh eating or processing. Tree: moderately vigorous; semi-spreading habit; fruit well-distributed throughout the canopy; annual and heavy bearing; immunity to apple scab and good resistance to fire blight (Erwinia amylovora) and moderate resistance to powdery mildew (Podosphaera leucotricha).

Dalinip. Intense striped, early maturing whole-tree mutation of Pinova. Origin: Lezigne France by G. Ligonnere; selected in 1997; USPP 18,482; 12 Feb. 2008.

Dalirail. Intense color, early maturing whole tree mutation of Imperial Gala. Origin: Lezigne France by G. Ligonnere; selected in 1998; USPP 18,483; 12 Feb. 2008.

Diva. Scab resistant cider apple for northern climates. Origin: Agriculture and Agri-Food Canada, St-Jean-sur-Richelieu, Quebec, by S. Khanizadeh. McIntosh x PRI 674; crossed 1971; tested as SJC7123-1; Canadian PBRO 06-5438; 21 Nov. 2008. Fruit: roundconic to somewhat oblong, some slightly ribbed and asymmetrical; medium, diameter 64-76 mm; ripens late-midseason, 1 week after Cortland; smooth, non-waxy skin, dark red flush, stripes over yellowish-green ground color, and prominent lenticels; flesh cream, crispy, juicy, firm, and rapidly oxidizing; sweet, and slightly tart. Tree: moderately vigorous; resistant to apple scab; little preharvest drop.

Diva ${ }^{\circledR}$. See Milwa.

Diwa $^{\circledR}$. See Milwa.

Dudek. Red sport of Caudle. Origin: East Wenatchee, WA, by B.F. Dudek. selected 1998; USPP 19,766; 24 Feb. 2009.

El Niño. Red sport of Royal Gala. Origin: Royal T Farms, Royal City, WA, by S.A. McDonald. selected 1996; USPP 18,512; 26 Feb. 2008 .

Emmons. Long storing apple with round fruit and dense, sweet flesh. Origin: Chance seedling found in orchard near Gleed, WA, by D.C. Emmons in 1978. USPP 18,946; 17 June 2008. Fruit: medium-large, $75 \mathrm{~mm}$ diameter, $65 \mathrm{~mm}$ height; ripens midseason; red-pink blush, darker red stripes over yellow-green ground color; flesh creamy yellow; firm and crisp; high soluble solids with balanced flavor and some aroma; smooth texture; no russeting. Tree: moderate-high vigor; annual bearing; blooms with Delicious.

Envy $^{\mathrm{TM}}$. See Scilate.

Eppich 2. Early ripening sport of TAC 114 Fuji. Origin: Mesa, WA by K. Eppich. selected 1998; USPP 18,004.

Frostbite. Small, red, late-midseason apple with tropical fruit or raw sugarcane aroma. Origin: University of Minnesota, Excelsior, MN, by D.S. Bedford, J.J. Luby, and D.K. Wildung. Parentage unknown; DNA fingerprinting does not support Malinda as maternal parent as recorded; Selected in 1922; tested as MN 447; introd. 2008. Fruit: globose to flat-globose; small to medium, 56-66 mm diameter; long stem; 80 to $95 \%$ maroon red over a yellow-gold groundcolor, striped pattern overcolor, often with a dappled appearance; sometimes russetted; flesh cream to light yellow; firm, crisp, juicy; sweet with unusual aroma of tropical fruit or raw sugarcane; stores 3-4 mo. Tree: very hardy (USDA zone $3 b$ ), low-medium vigor with spreading habit; some tendency to biennial bearing.

Fugachee. Yellow-green apple with prominent russetted lenticels, conical shape, and a distinctive, low-acid, sweet flavor. Origin: Bridgeport, WA, by G.S. Orozco. Chance seedling selected in 2001; USPP 20,190; 28 July 2009. Fruit: oblong-conic, no ribbing, slight calyx-end lobing; very large, $80 \mathrm{~mm}$ diameter, $85 \mathrm{~mm}$ height; yellow-green with very prominent russeted lenticels; occasional russeting on stem end but not basin; flesh cream, firm, juicy, and crisp; sweet, similar to Mutsu with some aroma; 2-3 week shelf life and 6 mo. storage life; susceptible to bitter pit on young trees; ripens $7 \mathrm{~d}$ after Golden Delicious. Tree: high vigor; upright-spreading habit; $50-65^{\circ}$ crotch angles; annual bearing; less susceptible to scab than Golden Delicious.

Fugachee Fuji. Earlier, redder sport of Fuji. Origin: Brewster, WA, by I. Clevenger. selected 1998; USPP 16,270; 21 Feb. 2006.

Fuji Fubrax $\left(K_{i k u^{\circledR}}\right)$. Red sport of Fuji. Origin: Eppan, South Tyrol, Italy by T. Braun. selected 2002; USPP 18761; 29 Apr. 2008.

Fujiko. Red sport of Nagafu 12 Fuji. Origin. Migliaro, Ferrara, Italy by M. Leis and C. Mazzola. selected 2002; EU PVR 2006/0766.

Galaval. Sport of Galaxy Gala with intense dark purple-brown skin over color having no defined stripes. Origin: Corze, Loire Valley, France, by A. Richard. selected 2002; USPP 19,909; 14 Apr. 2009.

Gold Chief ${ }^{\circledR}$. See Gold Pink.

Gold Pink (Gold Chief ${ }^{\circledR}$ ). Similar to Golden Delicious in flavor with no russeting. Origin: University of Bologna, Italy. Starkrimson x Golden Delicious; selected 1989; tested as 81.425.014; introd. 1998. Fruit: round conic, medium to large; skin smooth with 10$20 \%$ pink blush over yellow, no russeting; flesh firm, juicy; flavor balanced sweet-acid; ripens 7-10 d after Golden Delicious. Tree: moderate vigor, compact spur habit, blooms with Golden Delicious; early and annual bearing; no preharvest drop.

GUN-300. Early coloring, more upright whole-tree mutation of Rogers Red McIntosh. Origin: Crown Point, NY, by H. Gunnison. USPP 18,071. 25; Sept. 2007.

Junami $^{\circledR}$. See Milwa.

Kiku $^{\circledR}$. See Brak and Fuji Fubrax.

Lady in Red. Earlier, more colored sport of Cripps Pink. Origin: Hawkes Bay, New Zealand, by R.B. Mawley and E. F. Mawley; selected 1996; USPP 18,787; 6 May 2008.

Lady Laura. Sport of Cripp's Pink with earlier and more intense coloration. Origin: Borenore NSW, Australia, by M. Davidson and G. Davidson.USPP 19,826; 17 Mar. 2009.

La Flamboyante (Mairac $\left.{ }^{\circledR}\right)$. Crunchy, juicy, dense apple with aroma and good balance of sweetness and acidity. Origin: Eidg. 
Forschungsanstalt Institute Changins, Centre des Fougères, Conthey, Switzerland by C. Rapillard. Gala x Maygold; crossed 1986; introd. 2002. Fruit: round to obtuse-tapered; medium to large, $75-85 \mathrm{~mm}$ diameter; $75 \%$ orange to carmine red over a green-yellow ground color; flesh yellowish; very firm, hard and juicy; sweet-sour, aromatic flavor; ripens 5-10 d after Golden Delicious; not susceptible to bruising; 6 mo. storage life; does not become mealy or greasy in storage but can be sensitive to low temperature and $\mathrm{CO}_{2}$. Tree: medium-high vigor; small leaves; annual bearing; blooms earlymidseason; heavy bearing; requires thinning.

Mahana Red Braeburn (Redfield ${ }^{\circledR}$ ). Red sport of Braeburn. Origin: Nelson, New Zealand, by R.T. Field. USPP 17,268; 12 Dec. 2006

Mairac $^{\circledR}$. See La Flamboyante.

Masonova. Scab resistant apple with complete red overcolor, good cold storageability, and desirable eating characteristics including soft and fine-textured ivory-colored flesh that is very slow to oxidize. Origin: Agriculture and Agri-Food Canada, Kentville, NS by C.G. Embree and A.D. Crowe. Empire x S21-42-69; selected 1989; tested as S47-24-42; USPP 19,806; 10 Mar. 2009. Fruit: flat, globose with pronounced eye basin and stalk cavity; medium, $73 \mathrm{~mm}$ diameter; skin smooth with no bloom, some waxiness, very high amount of dark-red striped blush over creamy-white ground color; mild-sweet flavor; good cold storage ability; soft and fine textured, ivory flesh with some green and red venation surrounding the core; flesh absent to very weak oxidization; skin has solid, complete red coloration. Tree: moderate vigor; upright habit; spur bearing; annual bearing; very late bloom; resistant to scab.

McLaughlin Gala. Yellow sport of Kidds D-8 Gala. Origin: Portsmouth, Scioto County, OH, by R.T. McLaughlin. selected 1998; USPP 19,007; 8 July 2008.

Milwa (Diva ${ }^{\circledR}$, Diwa $^{\circledR}$, Junami $^{\circledR}$ ). Notable for globose fruit and luminous red color. Origin: Federal Research Station Agroscope Changins-Wadenswil, Wadenswil, Switzerland by M. Kellerhals and A. Aeppli. XII A 277 x Elstar; selected 1987; USPP 19,615; 6 Jan. 2009. Fruit: broad globose to conical globose to conical; medium, $77 \mathrm{~mm}$ diameter; little crowning; little greasiness; high amount and intensity of orange-red to red-purple overcolor over yellow-green ground color; little russet; flesh yellow-white, firm and crunchy; flavor aromatic and slightly acidic. Tree: weak-medium vigor, spreading habit, and $70-90^{\circ}$ crotch angles; blooms with Braeburn, Golden Delicious, Pinova, and Fuji; average susceptiblity to scab, susceptible to powdery mildew and fireblight; ripens 1 week before Golden Delicious.

Minneiska (SweeTango ${ }^{\circledR}$ ). Early ripening apple with unusually long storage life for that season. Origin: University of Minnesota, Excelsior, MN by D.S. Bedford and J.J. Luby. Honeycrisp x Minnewashta; selected 1999; tested as MN 1914; USPP 18,812; 13 May 2008. Fruit: conical; medium, 70 to $80 \mathrm{~mm}$ diameter; skin 70 to $95 \%$ red over a yellow-green ground color with distinct lenticels; flesh creamy white, very crisp, juicy and firm; flavor slightly tart; ripens 3-10 d before Gala; storage life 90 to $120 \mathrm{~d}$. Tree: medium vigor; slightly upright habit; $90^{\circ}$ crotch angles; annual bearing; susceptible to scab and fireblight; hardy in USDA zone 4; early blooming.

\section{Modi $^{\circledR}$. See CIVG 198.}

Myrto. Green, late-maturing apple with very crisp, aromatic and juicy fruit. Origin: Greek Pomology Institute, Naoussa, Greece by G. Syrgianidis. Golden Delicious x Granny Smith; crossed 1978; selected 1984. Fruit: oblong conical; large, $80-85 \mathrm{~mm}$ diameter; skin light green, waxy bloom, and small white lenticels like Granny
Smith, does not russet or sunburn; flesh creamy white, crisp and juicy; high sugar and acid, aromatic; firmer than Granny Smith; stores 6 mo. Tree: moderately vigorous; highly productive; susceptible to scab and powdery mildew.

Orion. Late, dessert-type, triploid apple, with good keeping quality and $V f$ scab resistance. Origin: Institute of Experimental Botany, Czech Republic by J. Tupy, O. Louda, and J. Zima. Golden Delicious x Otava; selected 1997; USPP 19,276; 30 Sept. 2008. Fruit: broad globose; large; skin surface bloom and greasiness of skin absent or very weak; skin ground color yellow with little light-red to orangered overcolor which may be absent, low amount of russet; flesh yellowish, medium to firm, very juicy; rich flavor, well-balanced in sugar and acid content; ripens late-season. Tree: medium-high vigor; upright-spreading habit; $70-80^{\circ}$ crotch angles; annual bearing; resistant to scab (Vf); low pollen fertility; fruits do not drop when ripe.

PB-148. Early season, highly colored apple having a good flavor and shelf life. Origin: Nevis Fruit Co. Ltd., Central Otago, New Zealand by J. McLaren. Gala x Jack Humm; crossed 1987; USPP 19,312; 7 Oct. 2008. Fruit: round; medium, $80 \mathrm{~mm}$ diameter; slight ribbing on basin cavity; attractive red blush with indistinct stripe over yellow ground color, indistinct lenticels; flesh white, firm and crisp with fine texture; slightly aromatic; ripens with Gala; stores up to 3 mo. Tree: average; average vigor; $55-90^{\circ}$ crotch angles.

PremA280. Dark-red fruited apple notable for its sweet flavor and crisp texture. Origin: Horticultural and Food Research Inst. of New Zealand, Hawkes Bay, New Zealand by A. White. Braeburn x Royal Gala; USPP 19,762; 24 Feb. 2009. Fruit: conical; thick skin, 60$100 \%$ dark red stripes over yellow ground color, lenticels inconspicuous, and no russet; flesh creamy, moderately firm, crisp, not gritty, very juicy; sweet, medium acidity, rich aroma, not bitter or astringent. Tree: moderate vigor; spreading habit; $70-90^{\circ}$ crotch angles; flowers mid-late-season and fruit ripens a few days before Royal Gala; similar to Royal Gala for disease and pest susceptibility.

PV 1027. Earlier maturing sport of Arends. Origin: Rogers, Ohio by D. Simmons and P. Simmons. selected 1997; USPP 16,620; 6 June 2006.

\section{Redfield $^{\circledR}$. See Mahana Red Braeburn}

Red Topaz. Redder, earlier-maturing sport of Topaz. Origin: Pencin u Liberce, Czech Republic by J. Tupy and O. Louda. selected 1998; USPP 18,895; 10 June 2008.

ROHO 3615. Red sport of Pinova. Origin: Langensendelbach, Germany by H. Hofman. selected 2000; USPP 17,672.

RS103-130. Compact, medium-sized apple tree, resistant to apple scab (Races 1 to 5), with variegated leaf colour and red fruit. Origin: Department of Primary Industry and Fisheries Research Station, Brisbane, Queensland, Australia by A. Zeppa. Royal Gala x CPR7T90; crossed 1993; USPP 20,028; 26 May, 2009. Fruit: asymmetrical conic with slight ribbing and calyx-end lobing; medium-large, $81 \mathrm{~mm}$ diameter, $71 \mathrm{~mm}$ height; glossy becoming greasy at maturity; red over yellow-green ground color; some stem cavity russeting; flesh yellow, medium firmness, and juiciness; flavor mild, sweet, low-acid and slight aroma; ripens midseason; 1week shelf life and $4 \mathrm{mo}$. storage life. Tree: low to moderate vigor; spreading to slight drooping habit; $60-90^{\circ}$ crotch angles; early season bloom period.

Ruby Pink. Later maturing, highly colored sport of Cripp's Pink. Origin: Main Ridge, Victoria, Australia by M.R. Staples. selected 1999; USPP 16,725; 27 June 2006. 
Scilate (Envy $\left.{ }^{\top \mathrm{M}}\right)$. Attractive red-fruited apple with excellent eating quality. Origin: Horticultural and Food Research Inst. of New Zealand, Hawkes Bay, New Zealand by A. White. Royal Gala x Braeburn; crossed 1985; USPP 20,477; 10 Nov. 2009. Fruit: globose conical with weak ribbing and medium crowning; medium, $81 \mathrm{~mm}$ diameter, $69 \mathrm{~mm}$ height; skin lacks bloom and greasiness at harvest, prone to russet in the stem and calyx cavities and sometimes on cheeks, and $70 \%$ red stripes over a yellow ground color; flesh very firm, crisp and juicy, cream-colored with medium texture; sweet flavor and slight acidity. Tree: medium vigor; spreading habit; spur bearing; blooms with Royal Gala, Delicious, and Granny Smith.

Seohong. Early-maturing apple with high levels of phytochemicals. Origin: National Institute of Horticultural \& Herbal Science, Jangangu, Suwon, Korea by J.H. Hwang, Y.U. Shin, D. Kim, S. Heo, and S.S. Hong. Tsugaru x Chukwang; crossed 1992; selected 2000; tested as Wonkyo Ga 33; introd. 2005. Fruit: globose, symmetrical with weak rib, and medium-large; skin smooth, glossy at harvest becoming waxy in storage, russet in stalk cavity; nearly $100 \%$ red flush and stripe overcolor on green-yellow to yellow ground color; flesh cream to light yellow, moderately firm and crisp; flavor sweet, juicy, comparable to Mondial Gala; 2 week shelf life and 3-4 mo. storage life; high concentrations of flavonoids, quercetin and rutin. Tree: moderate vigor; spreading habit; bears on spurs and shoots; annual bearing and prone to oversetting thus requiring heavy thinning.

Sirius. Triploid, scab resistant $(V f)$, late-season yellow apple. Origin: Institute of Experimental Botany, Pencin u Liberce, Czech Republic, by J. Tupy, O. Louda, and J. Zima. USPP 18,541; 4 Mar. 2008. Fruit: globose to globose-conical; medium-large, 75-80 mm diameter; yellow skin usually lacking overcolor; rich flavor, balanced sugar:acid; late-season; best eaten after 2 mo. storage; very good keeping quality. Tree: very vigorous; rounded and spreading habit; $80-90^{\circ}$ crotch angles; male-sterile triploid; blooms $2 \mathrm{~d}$ before Golden Delicious; annual bearing.

SweeTango ${ }^{\circledR}$. See Minneiska.

Walden. Redder, earlier whole-tree mutation of Honeycrisp. Origin: Milton, NY by J.D. Crist. USPP 15,946; 6 Sept. 2005.

Western Dawn. Pinkish-red, late-season apple with slow oxidative browning. Origin: State of Western Australia Breeding Program at Stoneville Research Station, Western Australia by J.E.L. Cripps and E. Melvin-Carter. Lady Williams x Golden Delicious; crossed 1976; selected in 1982; USPP 18,640; 25 Mar. 2008. Fruit: cylindrical, slightly crowned; medium-large, $70 \mathrm{~mm}$ diameter; green-yellow ground color and pink-red flush overcolor with weak striping on $60-90 \%$ of fruit; texture medium-firm; juicy; flesh light cream, slow to oxidize. Tree: high vigor; upright habit; $70^{\circ}$ crotch angles; chilling requirement low, 400-500 h.

WineCrisp $^{\mathrm{TM}}$. See Co-op 31.

ZARI. Early season apple, about 2 weeks before Gala, with good storability and shelf life, very crisp and juicy flesh. Origin: Fernelmont (Franc-Waret), Belgium by J. Nicolai, P. Van Laer, J. Keulemans, H. Eyssen, E. Pauwels, and I. De Wit. Elstar x Delcorf; crossed 1988; selected 1994; EU PVR No. 2005/2293. Fruit: oblong conical with weak ribbing; medium, $55 \mathrm{~mm}$ height and $63 \mathrm{~mm}$ diameter; deep basin with calyx-end crowning; approximately $75 \%$ orange-red striped overcolor on yellow-green ground color; flesh yellow, crisp, juicy, strongly aromatic. Tree: Average vigor; orthotropic spreading habit, $75-85^{\circ}$ crotch angles; annual bearing; slight tendency to biennial bearing.

\section{APRICOT AND APRICOT HYBRIDS}

Craig A. Ledbetter, USDA-ARS, San Joaquin Valley Agricultural Sciences Center, Parlier, CA
AC1. Ripe for commercial harvest 30 Apr. to 7 May in California's San Joaquin Valley. Origin: SDR Fruit, LLC, Vina, CA, by S.M. Southwick and D. Decalo. OrangeRed x O.P.; selected 1996. USPP 20,226; 18 Aug. 2009. Fruit: round, oblong and slightly beaked; 58 g; semi-clingstone; flesh tender and melting; ripens $10 \mathrm{~d}$ before OrangeRed; $30 \%$ of stones split at maturity. Tree: highly vigorous; growth habit upright and spreading; canopy dense; flowers selfincompatible; regular bearing and productive; chilling requirement $500-550 \mathrm{~h}$

Bolaroja. Firm, high-color, early-season apricot with aromatic flesh. Origin: USDA-ARS, Parlier, CA, by O. Tanner. OrangeRed $\mathrm{x}$ K149-70; crossed 1980; selected 1985; tested as K102-93; introd. 2009. Fruit: round; freestone; flesh fine-textured; flavor aromatic; average size for season; ripens between Kettleman and Primarosa. Tree: vigorous; growth habit spreading and open; flowers selfincompatible; more susceptible to powdery mildew (Sphaerotheca pannosa) than other commonly grown commercial apricots.

GA 10F. Vigorous self-incompatible apricot of medium size, with good color, flavor and production. Origin: Reedley, CA, by M. Gerawan. Parentage unknown. USPP 18,370; 25 Dec. 2007. Fruit: slightly oblong; freestone; medium, $91 \mathrm{~g}$; tends to crack in wet weather; ripens at least $10 \mathrm{~d}$ before Patterson; texture firm, moderate amount of coarse fibers; slight to moderate aroma. Tree: moderate vigor; growth habit upright and spreading; flowers self-incompatible, with Castlebrite or Patterson being adequate pollenizers.

Goldenmay. A large-fruited self-compatible early blooming apricot for the fresh market with solid orange skin. Origin: Le Grand, CA, by L.G. Bradford. Goldenblush x 16P245; crossed 2000; selected 2004; introd. 2009. USPP 20,104; 16 June 2009. Fruit: globose; large, $120 \mathrm{~g}$; freestone; skin moderate reddish orange that blends smoothly into a strong orange, medium thickness; flesh meaty, firm and melting with moderate, rich juice; mildly acidic and sweet in flavor. Tree: vigorous; growth habit spreading and dense; very productive and regular bearer; flowers self-fertile; early bloom period compared with other apricots, with Goldenblush bloom.

MC5. An attractively colored apricot, harvested 14-24 May in the San Joaquin Valley. Origin: by SDR Fruit, LLC, Vina, CA, by S.M. Southwick and D. Decalo. OrangeRed x O.P.; crossed 1993; selected 1996; introd. 2009. USPP 20,431; 20 Oct. 2009. Fruit: round to slightly round and oblong; large, $75 \mathrm{~g}$; freestone; skin glabrous; flesh firm and moderately crisp; ripens $23 \mathrm{~d}$ before OrangeRed. Tree: vigorous; growth habit upright and spreading; flowers self-incompatible; canopy dense; chilling requirement 550-600 h.

NJA150 (Sugar Pearls). Round, juicy, yellow-orange freestone apricot for the midseason with fine melting flesh. Origin: Rutgers, The State University of New Jersey, by J.C. Goffreda and A.M. Voordeckers. NJA103 x NJA45. USPP 18,639; 25 Mar. 2008. Fruit: round; freestone; small to medium, $37 \mathrm{~g}$; ground color yellow with freckled grayed-red blush; flesh moderately acidic, SS $18 \%$. Tree: vigorous; growth habit spreading; above average in height; dormant flower buds tolerant to at least $20^{\circ} \mathrm{C}$; self-fertile flowers that bloom later than other East Coast cultivars.

Primarosa. A highly colored midseason apricot for fresh market and shipping. Origin: USDA-ARS, Parlier, CA, by O. Tanner. K149-70 x O.P.; crossed 1983; selected 1987; tested as K51-71; introd. 2009. Fruit: pistil end distinctively flat with meaty and symmetrical cheeks; skin bright orange with strong blush on sun-exposed surfaces; freestone; ripens with Castlebrite and before Lorna. Tree: vigorous; growth habit erect; flowers self-incompatible; fruitful using Castlebrite or Patterson as pollinators.

\section{Pubescent-skinned Prunophora Hybrids}

Autumn Sprite. A yellow/orange-skinned interspecific with firm flesh and uniform fruit maturity throughout the tree, ripening 
approximately 5 weeks after Patterson apricot. Origin: Modesto, CA, by G.N Zaiger, L.M. Gardner, and G.G. Zaiger. 192LD95 x 63EG50; selected 1997. USPP 16,599; 30 May 2006. Fruit: globose, slightly flattened toward suture plane; medium, $88 \mathrm{~g}$; freestone; fibers few, very small and tender; much firmer than most commercial shipping apricots. Tree: vigorous; growth habit semi-spreading; regular bearing and productive; flowers self-compatible; chilling requirement approximately $550 \mathrm{~h}$.

Bella Cerise. Firm-fleshed interspecific bearing medium to large fruits with good flavor and eating quality. Origin: Modesto, CA, by G.N Zaiger, L.M. Gardner, and G.G. Zaiger. 38GH36 x 352LC448; selected 1997. USPP 18,815; 13 May 2008. Fruit: globose; mediumlarge $139 \mathrm{~g}$; flesh meaty, firmness similar to commercial plums; clingstone; flavor and eating quality good. Tree: vigorous; growth habit semi-spreading; regular bearer; flowers self-incompatible.

Bella Gold. Yellow-skinned, semi-freestone interspecific fruit of very good flavor and eating quality. Origin: Modesto, CA, by G.N Zaiger, L.M. Gardner, and G.G. Zaiger. $38 \mathrm{GH} 47$ x O.P.; selected 1997. USPP 17,826; 26 June 2007. Fruit: globose; semi-freestone; $113 \mathrm{~g}$; greater firmness than most commercial apricots; shipping and storage quality good. Tree: semi-vigorous; growth habit spreading; flowers self-incompatible; chilling requirement $600 \mathrm{~h}$.

Bella Royale. Orange-fleshed, clingstone interspecific fruit of medium size, good flavor, and storage quality. Origin: Modesto, CA, by G.N Zaiger, L.M. Gardner, and G.G. Zaiger. $75 Z 655$ x O.P.; selected 2003. USPP 19,925; 14 Apr. 2009. Fruit: globose; 122 g; flesh firm with a few small, tender fibers; clingstone; SS 20\%. Tree: vigorous; growth habit upright; regular bearer, productive; flowers self-incompatible; chilling requirement $800 \mathrm{~h}$.

Coral-cot. A self-fruitful interspecific that regularly bears large, orange-fleshed fruit of good flavor and eating quality. Origin: Le Grand, CA, by L.G. Bradford. 9Z38A x 160LH337; selected 2001. USPP 19,563; 9 Dec. 2008. Fruit: elongated, slightly flattened inward toward suture plane; large, $133 \mathrm{~g}$; firmer than most commercial apricots; flesh orange; freestone; shipping and storage quality good. Tree: vigorous; growth habit semi-spreading; productive, requires annual fruit thinning; flowers self-compatible; chilling requirement $400 \mathrm{~h}$.

Cot-N-Candy. A productive and regular-bearing interspecific with white flesh and excellent eating quality. Origin: Modesto, CA, by G.N Zaiger, L.M. Gardner, and G.G. Zaiger. 9Z37-A x O.P.; selected 1998. USPP 17,827; 26 June 2007. Fruit: globose, slightly flattened toward suture plane; medium, $62 \mathrm{~g}$; texture similar to apricot; fibers few and tender. Tree: vigorous; growth habit semispreading; regular and productive bearer; flowers self-incompatible; chilling requirement $800 \mathrm{~h}$.

Escort. Attractive, orange-fleshed interspecific with uniform ripening and fruit of good handling and shipping quality. Origin: Modesto, CA, by G.N Zaiger, L.M. Gardner, and G.G. Zaiger. 352LC164 x 31Z635; selected in 2003. USPP 18,537; 4 Mar. 2008. Fruit: nearly globose, slightly elongated and compressed in suture plane; large, $113 \mathrm{~g}$; freestone; no tendency to crack in wet weather. Tree: vigorous; growth habit semi-spreading; flowers self-compatible; chilling requirement 750 hours.

Late Brittney. A late-season self-fertile interspecific producing attractive yellow-orange fruit with very good flavor and eating quality. Origin: Modesto, CA, by G.N Zaiger, L.M. Gardner, and G.G. Zaiger. 192LD63 x O.P.; selected 1996. USPP 18,921; 10 June 2008. Fruit: slightly elongated, slightly flattened toward suture plane; large, $95 \mathrm{~g}$; flesh firmer toward skin surface, softer toward pit cavity; freestone; ripens $40 \mathrm{~d}$ after Patterson. Tree: vigorous; growth habit semi-spreading; regular bearing; flowers self-compatible; chilling requirement approximately $850 \mathrm{~h}$.

\section{BANANA}

Ricardo Goenaga, USDA-ARS, Tropical Agriculture Research Station, Mayaguez, PR

FHIA 2. Dessert banana (Musa acuminata AAAA). Origin: Fundación Hondureña de Investigación Agrícola, Cortés, Honduras.
Bunch: $14.4 \mathrm{~kg} ; 8$ hands, 116 fruits; third hand $1.9 \mathrm{~kg}$. Pseudostem: $2.9 \mathrm{~m}$ high; diameter $16 \mathrm{~cm}$; resistant to black Sigatoka (Mycosphaerella fijiensis).

FHIA 17. Dessert banana (Musa acuminata AAAA). Origin: hybrid developed by Fundación Hondureña de Investigación Agrícola, Cortés, Honduras. Bunch: $46.0 \mathrm{~kg} ; 12$ hands; 220 fruits; third hand $4.3 \mathrm{~kg}$. Pseudostem: $3.3 \mathrm{~m}$ high; diameter $23.6 \mathrm{~cm}$; tolerant to black Sigatoka.

FHIA 18. Apple flavored dessert banana (Musa acuminata AAAB). Origin: Fundación Hondureña de Investigación Agríciola, Cortés, Honduras. Bunch: weight $24.0 \mathrm{~kg}$; 9 hands; 134 fruits; third hand $2.8 \mathrm{~kg}$. Pseudostem: $3.1 \mathrm{~m}$ high; diameter $19.5 \mathrm{~cm}$; resistant to black Sigatoka; shelf life long.

Grand Nain. Cavendish dessert banana (Musa acuminata AAA), and the most important commercial cultivar in Central America and the Caribbean. Origin: unknown, probably a clonal selection from Central America within the Cavendish subgroup. Bunch: large, $24.4 \mathrm{~kg}$; 9 hands; 142 fruits; third hand $3.1 \mathrm{~kg}$. Pseudostem: $2.3 \mathrm{~m}$ high; diameter $16 \mathrm{~cm}$; susceptible to Fusarium wilt race 4 (Fusarium oxysporum f.sp. cubense) and black Sigatoka.

\section{BLACKBERRY}

Chad E. Finn, USDA-ARS, Horticultural Crops Research Laboratory, Corvallis, OR

John R. Clark and Sandra Sleezer, Department of Horticulture, University of Arkansas, Fayetteville, AR

APF-45 (Prime-Ark ${ }^{\circledR}$ 45). Thorny, erect primocane-fruiting blackberry. Origin: University of Arkansas, by J.R. Clark. APF-1 x Prime-Jim ${ }^{\circledR}$; crossed 2000; selected 2002; tested as APF-45, introd. 2009. USPP applied for. Fruit: medium-large to large; attractive; very firm; SS 9.7\%; good postharvest storage; ripens on floricanes 9 June in Clarksville, AR, $4 \mathrm{~d}$ after Natchez and Prime-Jim ${ }^{\circledR}, 4 \mathrm{~d}$ before Ouachita, ripens on primocanes 2 weeks after Prime-Jim ${ }^{\circledR}$ and Prime-Jan ${ }^{\circledR}$. Plant: very erect; thorny; good vigor; consistent high yields; moderate-high resistance to anthracnose (Elsinoe veneta); resistant to orange rust (Gymnoconia nitens).

Newberry. Thorny, trailing blackberry with high quality fruit that are similar in color and shape to 'Boysen' but that "bleed" much less in fresh market handling. Origin: USDA-ARS, Corvallis, OR, by C.E. Finn, B.C. Strik, B.M. Yorgey, R.R. Martin, and M.M. Stahler. ORUS 834-5 x ORUS 1045-14 (a Scottish hybrid of a tetraploid raspberry and a tetraploid blackberry are in the pedigree); crossed 1992; selected 1994; tested as ORUS 1324-1; introd. 2009. Fruit: dark purple, Boysen color; large, $7 \mathrm{~g}$; irregular, blocky, blunt conic; attractive; glossy; firm, comparable to Kotata; good texture but more noticeable seeds than Marion and Kotata; excellent sweet flavor but not the same as Boysen; SS and pH similar to Black Diamond; titratable acidity lower than Marion and Black Diamond; overall excellent processing characteristics; firm enough to ship in wholesale fresh market; ripens with Marion in midseason. Plant: trailing; thorny; extremely vigorous; very high yields, $50 \%$ greater than Marion; long fruiting laterals; machine harvests easily; not particularly susceptible to septoria leaf spot (Mycosphaerella rubi) or purple blotch (Septocyta ruborum); no vegetative or fruit symptoms of cane or leaf rust (Kuehneola uredinsis); hardiness not well tested but survived $-8{ }^{\circ} \mathrm{C}$ in northern Washington when Marion was severely damaged.

Prime-Ark ${ }^{\circledR}$ 45. See APF-45.

Wild Treasure. Thornless trailing blackberry with high quality processed fruit that are very small and can be mechanically harvested. Origin: USDA-ARS, Corvallis, OR, by C.E. Finn, B.C. 
Strik, B.M. Yorgey, M. Qian, R.R. Martin, and M. Peterson. GP 9-24 (wild selection of Rubus ursinus from Mount Hebo, OR) x Waldo; crossed 1996; selected 1998; tested as ORUS 1843-3, introd. 2009. Fruit: very black; very small, 2-3 g; uniform conic, much more uniform than Marion; very attractive; glossy; firm, comparable to Siskiyou; excellent texture comparable to Marion; lower SS and higher titratable acidity than Marion; flavor rated comparable to Marion and better than Chester Thornless; overall outstanding processing characteristics; ripens with Marion in midseason. Plant: trailing; thornless (Austin Thornless source); vigorous; thin canes that grow early in the season are brittle if not trained as they grow or trained early; hermaphroditic (maternal parent is dioecious); good yields comparable to Marion if canes treated gently; harvests easily by machine; ploidy, $2 n=8 x=56$ as estimated by flow cytometry; not particularly susceptible to septoria leaf spot or purple blotch; no vegetative or fruit symptoms of cane or leaf rust; winter hardiness not well tested but appears to survive cold winter temperatures at least as well as Marion.

\section{BLUEBERRY}

Mark Ehlenfeldt, USDA-ARS, Genetic Improvement of Fruits and Vegetables Laboratory, Henry A. Wallace Agricultural Research Center, Beltsville, MD

Alba. A midseason blueberry suitable for evergreen management under tunnels or open-air deciduous management with machine harvest. Origin: Univ. of Florida and Atlantic Blue Blueberry SL, by P.M. Lyrene, A. Abad Alamo, and J.U. Hayler Lopez. FL 95-209B x FL 97-24; crossed 1998 in Florida; selected 2003 in Almonte, Huelva, Spain; tested as S03-19-02; introd. 2009. USPP applied for. Fruit: light blue; slightly flattened; firm; pleasant acid blueberry flavor; ripens midseason. Plant: generally upright growth habit with evergreen foliage; requires cross-pollination for good fruit production; low chilling requirement.

Altair. An early- to midseason blueberry recommended for use in tunnels in an evergreen management system, selected in Almonte, Huelva, Spain. Origin: Univ. of Florida and Atlantic Blue Blueberry SL, by P.M. Lyrene, A. Abad Alamo, and J.U. Hayler Lopez. FL 904 x FL 96-32; crossed 1999 in FLorida; selected 2003 in Almonte, Huelva, Spain; tested as S03-38-04; introd. 2009. USPP applied for. Fruit: light blue; pleasant sweet flavor; ripens over a wide early to midseason range; easy to pick; good postharvest shelf life. Plant: rounded growth habit with attractive evergreen foliage; self-fertile; low chilling requirement.

Amatsubu-Boshi (Sweet Star). Large-fruited northern highbush blueberry with excellent eating quality. Origin: Gunma Horticultural Experiment Station, Sawa-Azuma, Gunma, Japan, by M. Horigome, M. Satoh, Y. Tachikawa, and T. Nakajoh. O.P. seeds of Collins and Coville collected 1987; selected 1991; tested as GBC-2; introd. 1999. registered as No.7176 by the Seedlings Law of Japan. Fruit: medium-large, $\sim 1.9 \mathrm{~g}$; flattened; blue; calyx end is large and medium in depth; scar medium and wet; ripens medium-late (late July in Japan); fruit detaches easily at harvest; resistant to splitting; slightly soft; medium sweetness and acidity; stores moderately well; edible quality is excellent. Plant: moderate productivity; medium vigor; slightly upright; blooms with Coville; large corolla; cold hardy; moderately easy to propagate by cuttings; high chilling requirement.

Azulema. A midseason blueberry suitable for evergreen management under tunnels. Origin: Univ. of Florida and Atlantic Blue Blueberry SL, by P.M. Lyrene, A. Abad Alamo, and J.U. Hayler Lopez. FL 90-4 x FL 96-32; crossed 1999 in Florida; selected 2003 in Almonte, Huelva, Spain; tested as S03-38-01; introd. 2009. USPP applied for. Fruit: light blue; slightly flattened; firm; high quality; superb aromatic blueberry flavor; ripens midseason. Plant: generally round to vase-shaped with evergreen foliage; self-fertile; low chilling requirement.
Blue Suede ${ }^{\mathrm{TM}}$. See TH-682.

Carmen. An early blueberry. Origin: Univ. of Florida and Atlantic Blue Blueberry SL, by P.M. Lyrene, A. Abad Alamo, and J.U. Hayler Lopez. FL 92-84 x FL 95-54; crossed 1996 in Florida; selected 2001 in Almonte, Huelva, Spain; tested as S01-13-08; introd. 2009. USPP applied for. Fruit: light blue; firm; excellent fruity flavor; easy to pick; ripens early; substantial postharvest shelf life. Plant: strong generally round to vase-shaped growth habit with foliage that is partially retained during winter; flowers early; selffertile; low chilling requirement.

Celeste. A midseason blueberry. Origin: Univ. of Florida and Atlantic Blue Blueberry SL, by P.M. Lyrene, A. Abad Alamo, and J.U. Hayler Lopez. FL 97-24 x Jewel; crossed 1997 in Florida; selected 2002 in Almonte, Huelva, Spain; tested as S02-04-01; introd. 2009. USPP applied for. Fruit: light blue; excellent aromatic sweet flavor; ripens midseason; very good postharvest shelf life. Plant: very vigorous; vase-shaped growth habit; evergreen foliage; self-fertile; adaptable to growing in different soil types; low chilling requirement.

Centra Blue. Large-fruited rabbiteye blueberry with extended late production. Origin: Plant \& Food Research. Ruakura Research Centre, Hamilton, New Zealand, by J. Scalzo, S. Miller, C. Edwards, J. Meekings, and P. Alspach. Centurion x Rahi; crossed 1988; selected 1996; tested as F130; introd. 2006; NZ PVR BLU014; 2006. Fruit: large; attractive bloom; good firmness; small scar; high phytochemical composition; good flavor; little grittiness. Plant: high yielding; vigorous with long clusters; flowers mid- to lateseason, similar to Centurion and Rahi; exceptionally late-fruitingseason with long duration compared to other cultivars; $50 \%$ ripens $\sim 1$ mo. after Powderblue and $\sim 3$ weeks after Centurion and Rahi; propagation by hardwood or softwood cuttings.

Corona. A vigorous, midseason blueberry suitable for evergreen management under tunnels. Origin: Univ. of Florida and Atlantic Blue Blueberry SL, by P.M. Lyrene, A. Abad Alamo, and J.U. Hayler Lopez. FL 95-54 x Jewel; crossed 1997 in Florida; selected 2002 in Almonte, Huelva, Spain; tested as S02-30-12; introd. 2009. USPP applied for. Fruit: light blue; slightly flattened; classic blueberry flavor; ripens midseason. Plant: generally vase-shaped growth habit; evergreen foliage; requires cross-pollination; low chilling requirement.

Dolores. An early blueberry with large, sweet berries. Origin: Univ. of Florida and Atlantic Blue Blueberry SL, by P.M. Lyrene, A. Abad Alamo, and J.U. Hayler Lopez. FL 97-45 x FL 95-70; crossed 1997 in Florida; selected 2002 in Almonte, Huelva, Spain; tested as S0226-03; introd. 2009. USPP applied for. Fruit: large, dark blue; crisp; very sweet flavor; ripens early. Plant: generally round growth habit; evergreen foliage; flowers early; self-fertile; low chilling requirement.

Farthing. Midseason southern highbush blueberry with large fruit size and high yields. Origin: Univ. of Florida, by P.M. Lyrene. FL 96-27 x Windsor; crossed 1996; selected 2000; tested as FL 00-75; introd. 2007. USPP 19,341. Fruit: large; dark blue; exceptional firmness; good scar; good flavor; good postharvest storage performance; ripens $5 \mathrm{~d}$ after Star. Plant: vigorous; somewhat spreading habit; excellent survival in the field; propagation by softwood cuttings; requires cross-pollination; chilling requirement $300 \mathrm{~h}$.

Hayabaya-Boshi (Early Star). Early northern highbush blueberry with excellent eating quality. Origin: Gunma Horticultural Experiment Station, Sawa-Azuma, Gunma, Japan, by M. Horigome, T. Okada, M. Hatakeyama, I. Kenmochi, M. Satou, and T. Nakajoh. O.P. seed of Collins and Coville collected 1987; selected 1991; tested as GBC-1; introd. 2004. Registered as No.11722 by the 
Seedlings Law of Japan. Fruit: medium, $\sim 1.6$ g; round; blue; calyx end large and shallow in depth; scar medium and wet; ripens early (early July in Japan); soft; medium sweetness and high acidity; edible quality is excellent. Plant: medium vigor; spreading.

Hortblue Petite. Ornamental, multiple-flowering highbush blueberry suitable for growing in pots and for home garden. Origin: Plant \& Food Research at the Ruakura Research Centre, Hamilton, New Zealand by J. Scalzo, S. Miller, C. Edwards, J. Meekings, and P. Alspach. O.P. seed of a dwarf V. corymbosum collected 1994; tested as M7. NZ PVR BLU013; 2003. Fruit: small; medium bloom; medium scar; good flavor; high phytochemical levels, particularly anthocyanin. Plant: production medium to high; bushy; flowers 2-3 times per season between September and April in New Zealand; first flowering is generally contemporary to Nui, Reka, and Duke; plants may produce one or more crops per year, the first generally ripens with Duke; propagation by hardwood or softwood cuttings.

Hortblue Poppins. Northern highbush blueberry suitable for home garden, with a distinctive "snap" or "pop" when fruit is eaten. Origin: Plant \& Food Research at the Ruakura Research Centre, Hamilton, New Zealand, by J. Scalzo, S. Miller, C. Edwards, J. Meekings, and P. Alspach. Nui x selection 1386; crossed 1988, selected 1996; tested as B8.3.10. NZ PVR applied for. Fruit: medium to small; good color; good bloom; small pedicel scar; good flavor and firmness; distinctive "snap" or "pop" when eaten; excellent postharvest shelf life; tolerant to anthracnose (Colletotrichum gloeosporioides) and botrytis (Botrytis cinerea). Plant: upright; distinctive leaf shape and habit with leaves turned inside and pointing upwards like an upturned umbrella; fruit well-displayed, predominantly on the perimeter of the bush; flowers, $\sim 1$ week after Nui and Duke; ripens midseason, similar to Bluecrop and Northland; propagation by hardwood or softwood cuttings.

Lucero. A midseason blueberry suitable for mechanical harvest, selected in. Origin: Univ. of Florida and Atlantic Blue Blueberry SL, by P.M. Lyrene, A. Abad Alamo, and J.U. Hayler Lopez. FL 91-160 x Windsor; crossed 1996 in Florida; selected in Almonte, Huelva, Spain; tested as S01-28-01; introd. 2009. USPP applied for. Fruit: light blue; round; refreshing blueberry flavor; formed in compact clusters; ripens midseason; suitable for mechanical harvest. Plant: upright habit with evergreen foliage; self-fertile; low chilling requirement.

Lucia. A late-season blueberry with excellent sweet flavor. Origin: Univ. of Florida and Atlantic Blue Blueberry SL, by P.M. Lyrene, A. Abad Alamo, and J.U. Hayler Lopez. FL 98-325 x FL 96-102; crossed 1999 in Florida; selected 2003 in Almonte, Huelva, Spain; tested as S03-60-01; introd. 2009. USPP applied for. Fruit: light blue; firm; excellent sweet flavor; ripens late-season. Plant: vaseshaped growth habit; deciduous foliage; flowers late; cross-pollination required; low chilling requirement.

Magna. A midseason blueberry with good postharvest storage quality. Origin: Univ. of Florida and Atlantic Blue Blueberry SL, by P.M. Lyrene, A. Abad Alamo, and J.U. Hayler Lopez. FL 98-19 x Millennia; crossed 1998 in Florida; selected 2003 in Almonte, Huelva, Spain; introd. 2009. USPP applied for. Fruit: large; light blue; strong acid flavor at harvest becoming sweeter a few days following harvest; ripens midseason; very good postharvest shelf life. Plant: vase-shaped with evergreen foliage; requires crosspollination for abundant fruit production; grows well in a dry climate in well-drained sandy soils; low chilling requirement.

Ohtsubu-Boshi (Large Star). Large-fruited northern highbush blueberry with excellent eating quality. Origin: Gunma Horticultural Experiment Station, Sawa-Azuma, Gunma, Japan, by M. Horigome, M. Satoh, Y. Tachikawa, and T. Nakajoh. O.P. seedlings of Collins or Coville, 1987; selected 1991; tested as GBC-3; introd. 1998. Registered as No.6926 by the Seedlings Law of Japan. Fruit: medium-large, $\sim 2.0 \mathrm{~g}$; oblate/flattened; dark blue; calyx medium in size and depth; ripens midseason; flesh firm, juicy, and contains many seeds; detaches easily at harvest; medium sweetness and slightly high acidity; excellent storage capability; resistant to splitting; edible quality is rich and excellent for fresh and processing. Plant: moderate productivity; vigorous; upright; medium in shape and growth; height 100-200 cm; strong canes; slow to develop new canes; blooms with Collins, medium size corolla; cold hardy; high chilling requirement; easily propagated by cuttings.

Pink Champagne. Cultivar designation formally assigned to blueberry selection $\mathrm{G} 435$, previously introd. as germplasm; see Register of New Fruit and Nut Cultivars, List \#43; HortScience 41:1101-1133 (2006).

Pink Lemonade. Cultivar designation formally assigned to blueberry selection ARS 96-138, previously introd. as germplasm; see Register of New Fruit and Nut Cultivars, List \#43; HortScience 41:1101-1133 (2006).

Primadonna. Early-season southern highbush blueberry with excellent flavor. Origin: Univ. of Florida, by P.M. Lyrene. O'Neal x FL 87-286; crossed 1988; selected 1992; tested as FL 92-84; introd. 2005; USPP 20,181. Fruit: large; medium blue; excellent scar, firmness, and flavor; ripens $12 \mathrm{~d}$ before Star in a concentrated period. Plant: vigorous; upright; moderately spreading habit; good survival in the field; readily propagated by softwood cuttings; flower buds sensitive to hydrogen cyanamide damage; requires cross-pollination; chilling requirement $300 \mathrm{~h}$.

Prince. Early-season rabbiteye blueberry adapted to hand harvest for the fresh market or mechanical harvest for the processing market. Origin: USDA-ARS Southern Horticulture Laboratory by S.J. Stringer, A.D. Draper, and J.M. Spiers. MS 598 x FL 80-11; crossed 1992; selected 1996; tested as MS 706; introd. 2008. Fruit: medium; good color, flavor, firmness and picking scar; ripens approx. $4 \mathrm{~d}$ before Climax; moderately susceptible to rain-induced splitting. Plant: high productivity; vigorous; upright; spreading; propagated readily by softwood or hardwood cuttings; chilling requirement 300 $400 \mathrm{~h}$.

San Joaquin. Midseason southern highbush blueberry selected for mechanical harvesting. Origin: Univ. of Florida, by P.M. Lyrene. FL 92-103 x FL 90-163; crossed 1992; selected 1996; tested as FLX-1; introd. 2009. USPP 19,342. Fruit: large; light blue; slightly flat; excellent scar, firmness, and flavor; fruit borne in loose clusters; releases easily; ripens 1 week after Star; stores well. Plant: vigorous; upright; open bush; good field survival; requires cross-pollination; chilling requirement $400-500 \mathrm{~h}$.

Scintilla. Early midseason southern highbush blueberry with excellent blue fruit color. Origin: Univ. of Florida, by P.M. Lyrene. FL 96-43 x FL 96-26; crossed 1997; selected 2000; tested as FL 00-267; introd. 2007; USPP 19,233. Fruit: very large; light blue; excellent scar, firmness, and flavor; fruit borne in loose clusters; ripens with Star. Plant: vigorous; semi-upright; medium to good field survival; flowers early; readily propagated by softwood cuttings; requires cross-pollination; chilling requirement 200-300 h.

Sevilla. A late-season blueberry with an aromatic sweet flavor. Origin: Univ. of Florida and Atlantic Blue Blueberry SL, by P.M. Lyrene, A. Abad Alamo, and J.U. Hayler Lopez. FL 98-19 x Millennia; crossed 1998 in Florida; selected 2003 in Almonte, Huelva, Spain; tested as S03-08-04; introd. 2009. USPP applied for. Fruit: large; light blue; slightly flattened; aromatic sweet flavor; ripens late-season. Plant: generally open-round to somewhat sprawling growth habit; commonly defoliates during the winter; requires cross-pollination; low chilling requirement. 
Snowchaser. Extremely early-season southern highbush blueberry. Origin: Univ. of Florida, by P.M. Lyrene. FL 95-57 x FL 89-119; crossed 1995; selected 1998; tested as FL 98-406; introd. 2005; USPP 19,503. Fruit: medium to large; light blue; good scar, firmness, and flavor; ripens $18 \mathrm{~d}$ before Star. Plant: vigorous; very early spring leafing; somewhat susceptible to stem blight (Botryosphaeria dothidea); readily propagated by softwood cuttings; requires cross-pollination; chilling requirement 100-200 h.

St. Cloud. Early midseason half-high blueberry. Origin: Univ. of Minnesota by J.J. Luby, D.K. Wildung, and C. Stushnoff. B19A x US 3; crossed 1967; selected 1972; tested as MN 167; introd. 1986. Fruit: medium; round to round-oblate; moderately soft; dark blue; sweet. Plant: a tall half-high, moderately upright, $1.5-1.75 \mathrm{~m}$ tall and $1.75 \mathrm{~m}$ wide; well-adapted in USDA zone 4; very low self-fertility; propagated by softwood cuttings or micropropagation.

Superior. Late-midseason half-high blueberry. Origin: University of Minnesota by J.J. Luby and D.K. Wildung. Parentage unknown; selected 1982; tested as MN 5451; introd. 2008. Fruit: medium; moderately firm; medium to light blue. Plant: moderately tall and upright, $1.25-1.5 \mathrm{~m}, 1.5-1.75 \mathrm{~m}$ wide; low to moderate self-fertility; adapted in USDA zones 3 and 4; productive at Grand Rapids, MN; propagated by softwood cuttings or micropropagation.

Suziblue. Early-season southern highbush blueberry. Origin: Univ. of Georgia, by D. Scott NeSmith. Star x TH-474; selected 2002; tested as TH-730; introd. 2009; USPP applied for. Fruit: large, 2.0$2.8 \mathrm{~g}$; medium-light blue; small, dry scar; excellent firmness; good flavor; ripens with Star in south and middle Georgia. Plant: vigorous; precocious; semi-spreading with medium crown; flowers with Star in south and middle Georgia; yield similar to or greater than Star in south Georgia; good leafing, even following mild winters; estimated chilling requirement $400-450 \mathrm{~h}$; suitable for fresh market; propagation easily by softwood cuttings; self-fertile, but crosspollination is recommended.

TH-682 (Blue Suede ${ }^{\mathrm{TM}}$ ). Midseason southern highbush blueberry for the home gardener and for "edible landscape" use. Origin: University of Georgia and USDA-ARS (Chatsworth, NJ), by D.S. NeSmith and M.K. Ehlenfeldt. MS-122 x MS-6; selected 2001; tested as TH-682; introd. 2008; USPP applied for. Fruit: medium to large, 1.7-2.0 g; abundant set; very light blue; medium scar; average firmness; pleasant, mild flavor; ripens 5-8 d after O'Neal, and 8-12 d before Climax in south and middle Georgia. Plant: vigorous, strong cane growth; open, semi-upright with narrow crown; flowers 10-15 d after O'Neal, and 3-8 d after Climax in south and middle Georgia; estimated chilling requirement 500-550 h; develops attractive fall coloring; suitable for home garden; propagation moderately easy by softwood cuttings; self-fertile to a degree, but will benefit from cross-pollination.

\section{CACAO}

\section{Ricardo Goenaga, USDA-ARS, Tropical Agriculture Research} Station, Mayaguez, PR

TARS 1. Productive, Forastero-type tree. Origin: USDA-ARS, Tropical Agriculture Research Station, Mayaguez, Puerto Rico, by R. Goenaga, H Irizarry, and B. Irish. UF-668 x Pound; cross made at Centro Agronómico Tropical de Investigación y Enseñanza, Turrialba, Costa Rica; selected in Puerto Rico in 1997; introd. 2002. Bean: 25.4 pod index; flavor profile of very complex nut character, like chestnut roasted with a blend of hazelnut skins. Tree: high yielding, more than $2,025 \mathrm{~kg} /$ ha dry beans.

TARS 9. Productive, Forastero-type tree. Origin: USDA-ARS, Tropical Agriculture Research Station, Mayaguez, Puerto Rico, by R. Goenaga, H Irizarry, and B. Irish. EET-400 x SCA-12; cross made at Centro Agronómico Tropical de Investigación y Enseñanza,
Turrialba, Costa Rica; selected in Puerto Rico in 1997; introd. 2002. Bean: 28.7 pod index; flavor profile of very mild chocolate notes up front with low overall bitterness and a distinct, persistent nut character; aftertaste has residual nut/nut skins note; very good chocolate. Tree: high yielding, more than $2,070 \mathrm{~kg} /$ ha dry beans.

TARS 14. Productive, Forastero-type tree. Origin: USDA-ARS, Tropical Agriculture Research Station, Mayaguez, Puerto Rico, by R. Goenaga, H Irizarry, and B. Irish. SCA-6 x EET-62; cross made at Centro Agronómico de Investigación y Enseñanza, Turrialba, Costa Rica; selected in Puerto Rico in 1997; introd. 2002. Bean: 36.6 pod index; flavor profile of good base chocolate notes with a deep woodsy source, with slight earthy, woodsy, and mushroom notes; overall flavor quite good, very complex and dark. Tree: high yielding, more than $2,400 \mathrm{~kg} / \mathrm{ha}$ dry beans.

TARS 23. Productive, Forastero-type tree. Origin: USDA-ARS, Tropical Agriculture Research Station, Mayaguez, Puerto Rico, by R. Goenaga, H Irizarry, and B. Irish. UF-668 x Pound-7; cross made at Centro Agronómico Tropical de Investigación y Enseñanza, Turrialba, Costa Rica; selected in Puerto Rico in 1997; introd. 2002. Bean: 24.5 pod index; flavor profile- rich, smooth chocolate profile up front with lots of deeper, mild dark wood notes; very good flavor and aftertaste. Tree: high yielding, more than $2,175 \mathrm{~kg} /$ ha dry beans.

\section{CITRUS}

Kim D. Bowman, T. Greg McCollum, and Ed W. Stover, USDAARS US Horticultural Research Laboratory, Ft. Pierce, FL

Tracy L. Kahn and Mikeal L. Roose, Department of Botany, University of California, Riverside, CA

Robert R. Krueger, USDA-ARS National Clonal Germplasm Repository for Citrus and Dates, Riverside, CA

Glenn C. Wright, Department of Plant Sciences, University of Arizona, Tucson, AZ

Allspice. Midseason tangelo. Origin: University of California Citrus Experiment Station, Riverside, California, by H.B. Frost. Imperial grapefruit x Willowleaf mandarin. Fruit: medium-small; orangeyellow; seedy; rind thick, slightly pebbled, adherent; flesh tender and juicy, with rich, tart, spicy flavor and aroma. Tree: mandarin-like in appearance; fruit does not hold well on tree.

Autumn Gold Late Navel. Late-maturing navel orange. Origin: Mourquong, NSW Australia by J.R. Pollock. Spontaneous mutation of Washington; selected 1965. Fruit: oblate to globose; 274 g; rind smooth, orange; navel present but not protruding; seedless; ripens February-May in California, slightly earlier than Powell navel orange; rind firmness similar to Powell and Lane Late, less firm than Chislett and Barnfield. Tree: similar to Washington with deep green foliage.

Barnfield Late Navel. Late-maturing navel orange. Origin: Ellerslie, NSW Australia by W. M. Barnfield and D. Barnfield. Spontaneous mutation from Washington navel; selected 1981; USPP 7,342; 2 Oct. 1990. Fruit: oblate to ovoid; large, 316.7 g; rind smooth, orange; navel present but not protruding; seedless; ripens February to May in Riverside, CA, slightly earlier than Powell; rind firmness similar to Chislett and slightly firmer than Autumn Gold, Powell, and Lane Late. Tree: medium vigor; dense and spreading growth habit.

Chislett Summer Navel. Late-maturing navel orange. Origin: G.J.K. Chislett, Kenley, Victoria, Australia. Probably a bud mutation from Washington navel. USPP 8,212; 27 Apr. 1993. Fruit: oblate to globose; $294.7 \mathrm{~g}$; rind smooth, orange; navel present and moderately protruding; seedless; ripens February-May in California, slightly earlier than Powell; rind firmness similar to Barnfield and slightly 
firmer than Autumn Gold, Powell, and Lane Late Tree: medium vigor; dense and spreading growth habit.

Clemenules (Nules, Clementina de Nules, Nulesina). Midseason clementine mandarin. Origin: Nules, Castellon de la Plana, Spain. Spontaneous mutation of standard Fina Clementine; selected 1953. Fruit: good size and quality; seedless; ripens slightly later than Fina; tendency to puff. Tree: vigorous; pruning can improve production and quality.

Cocktail (Mandalo). Pummelo hybrid. Origin: University of California Citrus Research Center, Riverside, California. Low-acid pummelo (CRC 2240) x Frua mandarin hybrid; crossed 1950s. Fruit: similar to grapefruit; medium; rind thin, smooth, and dark yellow; flesh dark yellow or yellowish-orange; extremely juicy and seedy with unique flavor; not suited for commercial production; too fragile for shipping; excellent dooryard juice cultivar. Tree: large; vigorous.

Corona Foothills. Lemon, currently popular in Arizona, but littleknown in California. Origin: Foothills Ranch, Corona, CA. Clonal selection of Villafranca. Fruit: similar to Eureka; medium; elliptical to oblong, sometimes obovate, with an inconspicuous neck or collar; apical mammilla medium to large; seeds few to none; yellow when mature; rind typically smooth, medium-thick 6-8 $\mathrm{mm}$, and adheres tightly; flesh, pale greenish-yellow with about 10 segments; juice content $30-45 \%$; harvest extends from the fall, winter, and into early spring, like Lisbon. Tree: vigorous; more open, less thorny, and less upright, than Lisbon; can be precocious.

Daisy. Midseason mandarin. Origin: Thermal, CA. Fortune $\mathrm{x}$ Fremont; crossed by USDA-ARS, Date \& Citrus Station, Indio, CA in 1963; named for wife of prominent Thermal nurseryman Dowlin Young. Fruit: medium; rind dark orange, easy peeler; moderately seedy; ripens midseason, January to March in Riverside, CA; yields well but has tendency to alternate bear; excessive splitting of fruit noted by some. Tree: average; moderate vigor.

DaisySL. Midseason, low-seeded mandarin. Origin: University of California, Riverside by T.E. Williams and M.L. Roose. Gamma irradiation of buds of Daisy; selected 2003; tested as Daisy IR1; introd. 2009; USPP applied for. Fruit: slightly obconate, no neck; medium-large; rind very smooth, deep orange, thin and moderately easy to peel; seeded; flesh moderately fine and orange red; flavor rich, sweet (SS 11.9-12.8\%), and distinctive; ripens December to January; up to $20 \%$ fruit splitting in some years. Tree: spreading when young, more spherical later; thornless; pollen viability low, 10-20\%.

Early Gold. Early season sweet orange. Origin: Selected in Florida from seed of Brazilian grown Seleta. Fruit: medium, similar to Hamlin but larger and with better color and flavor; colors well ahead of Hamlin; low seeded; ripens in central Florida November to January Tree: fairly large and vigorous.

Eureka SL ${ }^{\circledR}$. Seedless lemon. Origin: Musina Experimental Station, Limpopo Province, South Africa. Induced mutation of Eureka. PBR ZA 20043010; 29 Mar. 2004. Fruit: similar to Eureka; medium; elliptical to oblong, sometimes obovate with a short neck and medium to large apical mammilla; seedless; yellow; rind thin, $4 \mathrm{~mm}$, adheres tightly and can be smooth or slightly rugose; flesh pale greenish-yellow with 9-10 segments; juice content can be more than $55 \%$; harvest period from the fall, winter, spring, and into early summer, typical of Eureka; can be precocious. Tree: vigorous, spreading, and thornless, with similar growth habit to Eureka; not compatible with most trifoliate hybrid rootstocks, such as Carrizo, Troyer and C-35 citrange, and Swingle citrumelo; suitable for cooler growing regions, fruit set is poor in hot areas.

Fisher. Early season navel orange that is sometimes spelled Fischer. Origin: Armstrong Nursery by Mrs. Fisher. Budsport of Washington.
Fruit: color development similar to midseason navel selections; early juice maturity, several weeks ahead of most navels; holds well on tree; retains high brix/acid ratio well into midseason; fruit size and yields acceptable; sometimes with a thick rind and low juice percentage. Tree: similar to most other navel budlines.

Fukumoto. Early season navel orange. Origin: Kokawa-cho, Wakayama Prefecture, Japan by S. Fukumoto. Navel budline; introd. 1992. Fruit: rind color distinctive, deep reddish-orange; roundish, with a tendency to be slightly smaller than typical navels; early season, November to January in Riverside, CA; reaches color break 3-4 weeks before Washington; rind relatively thick at stylar end; brix increases earlier in season than for midseason navels, but acidity and juice content tend to be lower later in the season. Tree: average vigor, tendency to be smaller than Washington; tends to produce chimeras; in California there have been reports of a decline of Fukumoto on specific citrange rootstocks (Carrizo, C-35) but the cause of this decline has not been determined.

Gold Nugget. Late-maturing, seedless mandarin. Origin: University of California, Riverside, CA, by M.L Roose, T.E. Williams, R.K. Soost, And J.W. Cameron. Wilking (King tangor $\mathrm{x}$ Willowleaf mandarin) x Kincy (King tangor x Dancy tangerine); crossed 1955; selected by R.K. Soost and J.W Cameron 1975; introd. 2000. Fruit: slightly oblate; medium; rind pale orange, sometimes rough on young trees or those with light crops, fairly easy to peel, oil glands are numerous and easily ruptured; seedless even when crosspollinated, when present seeds are polyembryonic; flesh deep orange; flavor very sweet and rich; fruit generally reach maturity in February in California; retain good eating quality until late spring or early summer. Tree: vigorous; somewhat upright growth; somewhat thorny; pruning improves yield and fruit quality; diploid.

Itaborai. Early-midseason sweet orange. Origin: Brazil, selection of Seleta. Fruit: medium somewhat like Hamlin but larger with better color and flavor; color sometimes develops in advance of physiological maturity; low-seeded; primary use is processing; ripens November to January in northern hemisphere; early season like Hamlin; does not hold well on tree. Tree: fairly large and vigorous.

Kiyomi. Late-maturing tangor. Origin: Okitsu Branch Fruit Tree Research Station, Japan. Miyagawa satsuma x Trovita sweet orange; selected 1949; introd. 1979. Fruit: medium-large, 150-200 g; flat, orange-like appearance; rind thin, easy peeler; seedless; good juice content; scent like a sweet orange; flavor similar to navel orange; ripens February; hangs well on tree until April. Tree: Satsuma-like, drooping habit, semi-curled leaves.

Lane Late. Late-season navel orange. Origin: Curlwaa, NSW, Australia by L. Lane. Budsport of Washington navel; selected 1954. Fruit: size and shape similar to Washington, but with smaller navel and smoother peel; color less intense late in the season, and may re-green; ripens 4-6 weeks later than Washington and hangs well on tree until May or June without application of gibberellin or 2,4-D; rind thickness, juice percentage, and yields are intermediate for navel orange selections. Tree: similar to most other navel budlines.

LB8-9 (Sugar Belle ${ }^{\mathrm{TM}}$ ). Early midseason mandarin tangelo hybrid. Origin: University of Florida Citrus Research Center, Lake Alfred, FL, by F.G. Gmitter. Clementine x Minneola; crossed early to mid 1970s; selected 1985; tested as LB8-9; USPP applied for. Fruit: medium; rind dark orange/red, small neck like Minneola; flavor very rich and Minneola-like but with higher Brix and titratable acidity; darker interior and exterior color than Minneola; may produce more than 10 seeds per fruit with abundant cross-pollination but can be seedless or nearly so in solid, isolated blocks; early midseason, November to January in Florida, 4-6 weeks before Minneola. Tree: large; very vigorous; may require manipulation to control tree size 
and cropping; much more tolerant of Alternaria alternate than Minneola; yield superior to and more consistent than Minneola.

Limoneira 8A Lisbon. Highly productive clonal selection of Lisbon lemon and the most popular lemon selection grown in California and Arizona. Origin: Limoneira Co., Santa Paula, CA. Clonal selection of Lisbon. Fruit: typical of Lisbon; medium; elliptical to oblong, with an inconspicuous neck and medium to large apical mammilla; yellow when mature; rind is medium-thick, $6-8 \mathrm{~mm}$, adheres tightly and can be smooth or slightly rugose; flesh pale greenish-yellow, about 10 segments; typically 2-5 seeds per fruit; juice content 30$45 \%$; harvest extends from the fall, winter and into early spring; can be precocious. Tree: vigorous, upright, spreading, densely-foliated and thorny; somewhat more resistant to frost than Eureka due to its dense foliage.

Limoneira Seedless. Early-bearing seedless lemon. Origin: Limoneira Co., Santa Paula, CA, by N. Grech and E. Ekenler; selected in Adana, Turkey from an old line nucellar block. Parentage unknown, but probably the result of a hybrid between a lemon of the Femminello-type lemons and the Interdonato lemon; selected 1998; USPP 17,510; 20 Mar. 2007. Fruit: medium; round to slightly oval or elliptical, with an inconspicuous neck and distinct apical mammilla; typically seedless, except the Verdelli crop which may have less than $1 \mathrm{seed} / 5$ fruit; yellow; rind is thin 3-4 mm, adheres tightly, smooth or slightly rugose; flesh pale greenish-yellow with about 10 segments; juice content 30-40\%; may be stored for 6 mo. in controlled atmosphere; harvest extends from August to March in Riverside, CA and Adana, Turkey; in some areas can be manipulated with irrigation stress to produce summer flowering and hence a Verdelli crop. Tree: vigorous; upright and spreading; densely-foliated; thorns are persistent in growth, but are reduced in number as the tree ages; fruit borne predominantly inside the canopy, resulting in less scarring.

Limonero Fino 49. The most popular winter lemon selection in Spain, with some Arizona production. Origin: Murcia, Spain, by A. Garcia Lidón. Selection of Fino (also known as Mesero or Primofiori) lemon; selected in the mid 1970s. Fruit: similar to Lisbon; medium; elliptical to oblong, with an inconspicuous neck and medium to large apical mammilla; yellow when mature; rind medium-thick 6-10 mm, adheres tightly and can be smooth or slightly rugose; flesh is pale greenish-yellow with about 10 segments; typically 1-4 seeds/fruit; harvest extends mainly in the fall, winter, and early spring, typically earlier than Lisbon. Tree: tree is vigorous; upright; densely-foliated; longer and more numerous thorns than Lisbon; can be precocious.

Mandared (Red Nules). Red-pigmented tangor. Origin: CRAACM, Acireale, Italy, by G. Russo, S. Recupero, and R.R. Giuseppe. Triploid cross of Nules clemantine $(2 \mathrm{x}) \mathrm{x}$ Tarocco orange $(4 \mathrm{x})$; EUPVR applied for. Fruit: oblate; $170 \mathrm{~g}$; intense orange; moderately adherent pulp, easy peeler; novel anthocyanin internal pigmentation; ripens late, February to April Tree: upright; spreading habit; moderate spininess, similar to Tarocco.

Melogold. Triploid seedless pummelo-grapefruit hybrid. Origin: University of California Citrus Research Center, Riverside, CA by R.K. Soost and J.W. Cameron. Low acid pummelo (CRC 2240) x Marsh grapefruit (4x); crossed 1958; introd. 1985. USPP 6,001; 1 Sept. 1987. Fruit: shape similar to Marsh but larger; rind smooth to slightly pebbled, color similar to Marsh late in season; flesh tender and juicy; fruit quality good, brix higher and acids lower than Marsh, sometimes some bitterness; seedless; adapted to inland areas of California; ripens November to February in central California and December to March in Southern California; can yield well but has tendency to alternate bear. Tree: similar in growth and habit to grapefruit trees, most fruit born interior.

Nordmann Seedless. Seedless kumquat. Origin: De Land, FL by G.O. Nordmann. Nagami x O.P. Fruit: similar to Nagami, with a slightly different shape, lighter colored skin; medium, up to $5 \mathrm{~cm}$ long and $2 \mathrm{~cm}$ wide; teardrop shape, tapered toward stem end; rind thick, yellow-orange, sweet; pulp tart, fairly juicy; flavor like Nagami; seedless; fruits frequently hang in ornamental clusters; season December to June in Riverside, CA. Tree: small-medium, similar to standard Nagami; becomes semi-dormant in winter.

Pehrson Valencia \#3. Late-season Valencia orange. Origin: Orange County, CA by J. Pehrson who selected a number of mature, productive, true-to-type, high yielding Valencia source trees in the 1950s and early 1960s; budwood from seedlings grown from seeds of these trees were budded on Troyer citrange and grown in Brea, CA for 15 years; budwood was taken from these trees for clean up by the California Citrus Clonal Protection Program and Pehrson Valencia \#3 resulted. Fruit: medium; oblong to spherical; rind orange early in season with minimal regreening by late July in CA; seeds few to none; ripens late with good fruit size distribution. Tree: similar to most other Valencia orange selections.

Pehrson Valencia \#4. High-yielding Valencia orange. Origin: Orange County, CA by J. Pehrson who selected a number of mature, productive, true-to-type, high-yielding Valencia source trees in the 1950s and early 1960s; budwood from seedlings grown from seeds of these trees were budded on Troyer citrange and grown in Brea, CA for 15 years; budwood was taken from these trees for clean up by the California Citrus Clonal Protection Program and Pehrson Valencia \#4 resulted. Fruit: medium; oblong to spherical; rind color is good early in season but regreening results in greater than $65 \%$ yellowgreen or green in color by late July in CA; seeds few to none; high yields and good size distribution of fruits with very few small fruit. Tree: similar to most other Valencia orange selections.

Rohde Summer Navel. Late-maturing navel orange. Origin: Harkhill Farm, by P.W. McLaren. Victoria Australia. Spontaneous mutation from unknown navel; selected in early 1980s. USPP 7,651; 17 Sept. 1991. Fruit: 257.7 g; globose; rind orange, slightly rough late in season; seedless; ripens February to May but earlier in maturity than Powell in California. Tree: vigorous; spreading growth habit.

Ruby. Midseason blood orange. Origin: Mediterranean area (country unknown), introd. to USA about 1880 . Fruit: medium; globose to slightly oblong, faint areolar circular furrow or ridge; rind mediumthick, finely pitted, lightly pebbled; color good, reddish flush under favorable conditions; flesh tender and juicy, orange with streaks, not flecks, of red under favorable conditions; seeds relatively few; unreliable and variable cropping in many climatic conditions; best color and quality in California in hot interior areas, coastal plantings do not color; in Florida, has not been as productive as Hamlin, and fruit do not color, however, peel develops a deeper orange color than Hamlin and juice has a higher color score and more pleasing flavor. Tree: moderately vigorous; compact to medium-large; productive.

\section{Shasta Gold ${ }^{\circledR}$. See TDE2}

Shiranui (Dekopon). Late-season mandarin hybrid. Origin: National Institute of Fruit Tree Science, Tsukuba, Ibaraki, Japan. Kiyomi tangor (Miyagawa x Trovita) x Nakano No. 3 Ponkan. Fruit: large, $230 \mathrm{~g}$; oblate with distinctive necked base; rind orange, somewhat rough; high sugar content, SS 14-16\%, and acidity 1.0$1.2 \%$; ripens mid-February to early March Tree: moderate vigor; upright growth when young then broadening at fruiting.

Smith Red. Red-fleshed (anthocyanin-pigmented) orange. Origin: Merleen Smith residence, Moorpark, CA, c. 1988. Introd. by California Citrus Clonal Protection Program 2004. Originally believed to be a spontaneous mutation of backyard Valencia tree and named 'Smith Red Valencia', but this parentage seems unlikely. Fruit: good, typically larger than Moro; somewhat variable shape; globose to ovoid with a depressed base, possibly due to juvenility; rind frequently 
heavily blushed, texture more pebbled than Moro or Tarocco; flesh deeply pigmented by anthocyanin, less tender than Tarocco; flavor very good, sweeter than Moro; seeds few; ripens late winter in Riverside; holds on the tree past Moro. Tree: vigorous; carries a good crop.

Sugar Belle ${ }^{\mathrm{TM}}$. See LB8-9.

Tahoe Gold ${ }^{\circledR}$. See TDE3.

Tangor Norin No. 8 (Setoka). Late-season mandarin hybrid. Origin: National Inst. of Fruit Tree Science, Nagasaki, Japan, by R. Matsumoto, M. Yamamoto, T. Kuniga, T. Yoshioka, N. Mitani, N. Okudai, Y. Yamada, K. Asada, H. Ikemiya, K. Yoshinaga, S. Uchihara, I. Oiyama, and H. Murata. Kuchinotsu No. 37 (Kiyomi x Encore No. 2) x Murcott; registered as Tangor Norin No. 8; introd. 1998. Fruit: 200 - 280 g; oblate; rind thin, orange to deep orange, easy peeler; flesh tender and juicy; flavor pleasant, aromatic, similar to Murcott; ripens in February in Japan; acids low, 0.8-1.2 g/100 mL; high SS $12-13 \%$; nearly seedless, but seeds are polyembryonic. Tree: intermediate to weak vigor; intermediate to spreading growth habit; small thorns; resistant to citrus scab (Elsinoe fawcetti) and canker (Xanthomonas axonopodis).

TDE2 (Shasta Gold ${ }^{\circledR}$ ). Late-maturing, low-seeded mandarin. Origin: University of California, Riverside, by M.L. Roose, T.A. Williams, R.K. Soost, and J.W. Cameron. (Temple tangor x Dancy (4x) mandarin) x Encore mandarin; crossed 1973; introd. 2002; USPP 15,461; 4 Jan. 2005. Fruit: large; oblate; rind deep orange, sometimes rough on young trees or those with light crops, fairly easy to peel; flesh deep orange, juicy, and richly flavored; less than one seed per fruit in mixed blocks, seeds appear monoembryonic; ripens mid-February in California; fruit holds well on the tree. Tree: vigorous; dense, rounded canopy; fairly thorny; triploid.

TDE3 (Tahoe Gold ${ }^{\circledR}$ ). Midseason, low-seeded mandarin. Origin: University of California, Riverside, by M.L. Roose, T.A. Williams, R.K. Soost, and J.W. Cameron. (Temple tangor x Dancy $(4 \mathrm{x})$ mandarin) x Encore mandarin; crossed 1973; introd. 2002; USPP 15,703; 29 Mar. 2005. Fruit: medium-large; oblate with a small neck; rind deep orange, sometimes rough on young trees or those with light crops, fairly easy to peel, but membranes thin and easily broken; flesh deep orange, very juicy, and richly flavored; less than one seed per fruit in mixed blocks, seeds appear monoembryonic; ripens mid-January in California; fruit holds fairly well on the tree. Tree: vigorous; dense, rounded canopy; fairly thorny; triploid.

TDE4 (Yosemite Gold ${ }^{\circledR}$ ). Mid-late-season, low-seeded mandarin. Origin: University of California, Riverside, by M.L. Roose, T.A. Williams, R.K. Soost, and J.W. Cameron. (Temple tangor x Dancy (4x) mandarin) x Encore mandarin; crossed 1973; introd. 2002; USPP 16,289; 28 Feb. 2006. Fruit: large; oblate; rind very deep orange, sometimes rough on young trees or those with light crops, easy to peel; less than one seed per fruit in mixed blocks, seeds appear monoembryonic; flesh deep orange, moderately juicy, and richly flavored; maturity is generally mid-February in California; fruit holds fairly well on the tree. Tree: vigorous; dense, rounded canopy; slightly thorny with short thorns; triploid.

Tango. Mid-late-season, seedless mandarin. Origin: University of California, Riverside by M.L. Roose and T.E. Williams. Obtained by gamma irradiation of buds of W. Murcott mandarin; irradiated 1995; introd. 2006; USPP 17,863; 10 July 2007 Fruit: medium-large; somewhat oblate; rind deep orange, smooth, easy to peel; flesh deep orange, finely textured, juicy, and richly flavored; less than 0.2 seed per fruit in mixed blocks, seeds polyembryonic; ripens late-January in California; fruit holds fairly well on the tree. Tree: upright; thornless; pollen viability very low; precocious; diploid.

US Early Pride. Early season, seedless mandarin. Origin: USDAARS, Ft. Pierce, FL, by T.G. McCollum and C.J. Hearn. Obtained by gamma irradiation of buds of Fallglo mandarin; irradiated 1991; selected 1995; tested as 1-62-122; introd. 2009. Fruit: $7.5 \mathrm{~cm}$ diameter; oblate, flattened at apex, usually with small navel on blossom end; calyx usually retained when picked; rind Mikado orange to Salmon orange, smooth, prominent oil glands, $0.3-.5 \mathrm{~cm}$ thick, and easily removed; $12-13$ segments separate easily; segments less prone to rupture than in Fallglo; flesh zinc orange, juicy; flavor typical of Fallglo; juice highly colored, suitable for juice blending; typically completely seedless, although some fruit may have as many as six seeds; ripens in Florida by mid-October and maintains good quality on the tree through about mid-November. Tree: moderately vigorous; thornless; upright and slightly spreading with fairly dense foliage; appears to be somewhat less cold hardy than most Florida mandarin hybrids; pollen viability low.

US Seedless Pineapple. Seedless midseason sweet orange. Origin: USDA-ARS, Fort Pierce, FL, by T.G. McCollum, C.J. Hearn, and K.D. Bowman. Ridge Pineapple seeds irradiated 1970; tested as USDA 1-10-60; introd. 2009. Fruit: essentially identical to standard Pineapple, except for low seed count; 7.1-7.4 cm diameter; shape and peel characteristics rated as good by processors; fruit seldom plug (stem end peel disruption); SS 10.3-11.1\%, comparable to Pineapple; ripens January or February in central Florida; juice color scores good, exceed CN 36; 0.2 seeds per fruit, less than Pineapple so better fresh market potential. Tree: typical of Pineapple, but may be less prone to alternate bearing; yields comparable with Pineapple on various rootstocks; less prone to fruit drop than Pineapple, suggesting harvestable yield may be greater.

Valentine. Pigmented pummelo hybrid. Origin: University of California, Riverside by T. Siebert, O. Bier, D. Karp, G. Vidalakis, and T. Kahn. Siamese Sweet (CRC 2240) pummelo x (Ruby blood orange x Dancy mandarin); crossed in the 1950s; intod. 2009. Fruit: large, width $10.8 \mathrm{~cm}$, height $11.0 \mathrm{~cm}, 531.1 \mathrm{~g}$; pyriform to spheroid, slight to pronounced neck; rind medium to dark yellow, moderately smooth; flesh red, somewhat variable distribution and intensity; ripens around $14 \mathrm{Feb}$. in California; seedy, 27.6 seeds per fruit; borne singly on inner parts of canopy. Tree: vigorous; spreading with medium density; thorns absent.

Vernia. Mid-late-season sweet orange with high quality for processing. Origin: unclear; Vernia has been considered to be a synonym for Berna, a common Spanish sweet orange; the introduction of Vernia to Florida may not represent the traditional Spanish type. Fruit: small to medium; oval to ellipsoid; flesh well-colored; sweet flavor, moderate juice content; low-seeded; ripens medium-late in February, earlier than Valencia with similar quality and higher yields; use in Florida is processing. Tree: slightly less vigorous than Valencia; precocious; yields well.

Westin. Early season sweet orange. Origin: Brazil; originally called Clementina but renamed in honor of Prof. Philippe Westin Cabral de Vasconcellos to avoid confusion with Clementine mandarins. Fruit: small-medium; deep orange; high juice content; rich flavor with relatively high acidity; virtually seedless; ripens June-July in São Paulo State, Brazil, and in Florida ripens early, two weeks before Hamlin; primarily for processing but excessive preharvest drop and reduced yields have limited its use in Florida. Tree: large; vigorous; spreading; sets large crops.

Yellow Star Seedless. A triploid, seedless, early bearing lemon. Origin: Acireale, Italy, by G.R. Recupero, G. Russo, and S. Recupero. (C. limon femminello $\mathrm{x}$ Pera de Commendatore) $(2 \mathrm{x}) \mathrm{x}$ Doppio Lentini (4x); crossed 1999; selected in Aziendo San Gregorio (RC), Sicily 1999; USPP 17,520; 27 Mar. 2007. Fruit: medium; ovoid, with inconspicuous neck and slight apical mammilla; rind yellow, smooth, 4-8 mm, adheres tightly; flesh pale greenish-yellow; 8-10 segments; juice content 30-40\%; seedless; may be stored for 6 mo. in controlled atmosphere; harvest extends from late August to January in Riverside, CA and Sicily, Italy. Tree: 
vigorous; upright; precocious; densely-foliated; thorny and thorns are persistent in growth, but are reduced in number as the tree ages; fruit borne predominantly inside canopy, resulting in less scarring; highly tolerant of Mal secco (Phoma tracheiphila); triploid.

Yosemite Gold $^{\circledR}$. See TDE4.

\section{CITRUS ROOTSTOCK}

Kim D. Bowman, T. Greg McCollum, and Ed W. Stover, USDAARS US Horticultural Research Laboratory, Ft. Pierce, FL

Tracy L. Kahn and Mikeal L. Roose, Department of Botany, University of California, Riverside, CA

Robert R. Krueger, USDA-ARS National Clonal Germplasm Repository for Citrus and Dates, Riverside, CA

Glenn C. Wright, Department of Plant Sciences, University of Arizona, Tucson, AZ

African shaddock x Rubidoux trifoliate. Citrus rootstock. Origin: University of California, Riverside, by J. Menge. African shaddock (C. maxima) x Rubidoux trifoliate (Poncirus trifoliata). Cross made and selected by J. Carpenter and J. Furr (USDA-ARS, Indio, CA); introd. 1989. Plant: large and vigorous; fruit typically numerous; $15-$ 30 seeds/fruit, polyembryonic, high percentage of nucellar seedlings. Rootstock performance: high tolerance to phytophthora root rot (Phytophthora parasitica) and citrus nematode (Tylenchulus semipenetrans); stunted by some isolates of Citrus tristeza virus (CTV); in the absence of CTV, very vigorous and productive with orange scions; fairly susceptible to iron chlorosis on calcareous soils, similar to Carrizo; salinity tolerance not known; fruit size good, brix may be somewhat low.

Bitters trifoliate hybrid. Citrus rootstock. Origin: University of California, Riverside, by M.L. Roose. Sunki mandarin x Swingle trifoliate; crossed and selected by J. Carpenter and J. Furr, USDAARS, Indio, CA; tested as C-22; introd. 2009. Plant: somewhat dwarf; fruit numerous; 13 seeds/fruit, polyembryonic; high percentage of nucellar seedlings. Rootstock performance: seedling vigor in nursery similar to Carrizo but seedlings often branched; moderate tolerance of $P$. parasitica root rot and somewhat susceptible to citrus nematode; tolerant to California isolates of CTV; with orange scion produces a semi-dwarf tree, productive for its size; very tolerant to iron chlorosis on calcareous soils; salinity tolerance not known; freeze tolerance similar to Carrizo; fruit size and quality scions on this rootstock are very good; a very promising rootstock for grapefruit in Texas.

Carpenter trifoliate hybrid. Citrus rootstock. Origin: University of California, Riverside, by M.L. Roose. Sunki mandarin x Swingle trifoliate. crossed and selected by J. Carpenter and J. Furr, USDAARS, Indio, CA; tested as C-54; introd. 2009. Plant: large; fruit numerous and seedy, 11 seeds/fruit, polyembryonic, high percentage of nucellar seedlings. Rootstock performance: seedlings vigorous in nursery; moderate tolerance to $P$. parasitica root rot and good resistance to citrus nematode; tolerant to California isolates of CTV; with orange scion produces a large, vigorous tree; somewhat tolerant to iron chlorosis on calcareous soils; salinity tolerance not known; freeze tolerance similar to Carrizo; fruit size and quality good.

Fraser Seville. Sour orange hybrid citrus rootstock. Origin: unknown but suspect the same as Smooth Flat Seville, which was received by USDA-ARS, Orlando as seed from Australia in 1963; may be a distinct selection of the Smooth Flat Seville types. Plant: more or less similar to other sour orange and sour orange hybrids; medium vigor; tree and foliage similar to Poorman, but tree commonly more vigorous and larger. Rootstock performance: reported to have properties similar to sour orange but with improved resistance to CTV; has some use as a rootstock in Florida but is untried in California; a defect for rootstock use is the low level of nucellar embryony ( $60 \%$ or less).

Furr trifoliate hybrid. Citrus rootstock. Origin: University of California, Riverside by M.L. Roose. Sunki mandarin x Swingle trifoliate; crossed and selected by J. Carpenter and J. Furr, USDAARS, Indio, CA; tested as C-574; introd. 2009. Plant: medium; fruit numerous and seedy, 11 seeds/fruit, polyembryonic, high percentage of nucellar seedlings. Rootstock performance: seedling vigor in nursery similar to Carrizo; excellent tolerance to $P$. parasitica root rot and very resistant to citrus nematode; tolerant to California isolates of CTV; with orange scion produces a medium to large tree; somewhat tolerant to iron chlorosis on calcareous soils; salinity tolerance not known; freeze tolerance similar to Carrizo; fruit size and quality good.

US-802. Citrus rootstock. Origin: USDA-ARS, Fort Pierce, FL by K.D. Bowman. Siamese pummelo (C. grandis) x Gotha Road trifoliate orange (P. trifoliata); tested as FF5-23-65, HRS-802 or US-802; introd. 2007. Plant: medium; fruit numerous and seedy, brix may be somewhat low; seed polyembryonic and producing few off-type seedlings. Rootstock performance: vigorous, about as large as trees on Rough Lemon; trees grafted with sweet orange, mandarin, and grapefruit are highly productive; freeze tolerance is moderate; appears tolerant to $P$. nicotianae root rot, Florida isolates of CTV, Florida citrus blight, and the $P$. palmivora/Diaprepes abbreviatus weevil complex in poorly drained soils; tolerance to calcareous soils and salinity not known.

US-812. Citrus rootstock. Origin: USDA-ARS, Indio, CA by J. Furr. Sunki mandarin $(C$. reticulata) $\mathrm{x}$ Benecke trifoliate orange $(P$. trifoliata); tested by D. Hutchison, H. Wutscher, and K.D. Bowman, USDA, Orlando, FL as HRS-812; introd. 2001 by K.D. Bowman, USDA-ARS, Ft. Pierce, FL. Plant: medium; fruit numerous and seedy, seed polyembryonic and producing few off-type seedlings. Rootstock traits: moderately vigorous, about the same size as trees on Carrizo rootstock; trees grafted with sweet orange, mandarin, and grapefruit are highly productive; fruit size and quality are very good; freeze tolerance good; high tolerance to $P$. nicotianae root rot, Florida citrus blight, and Florida isolates of CTV; tolerant to calcareous soils up to $\mathrm{pH} 8.0$; appears susceptible to damage from the $P$. palmivora/D. abbreviatus weevil complex in poorly drained soils; salinity tolerance not known.

US-852. Citrus rootstock. Origin: USDA-ARS, Fort Pierce, FL, by K.D. Bowman and H.K Wutscher. Changsha mandarin (C. reticulata) x English Large Flowered Trifoliate Orange ( $P$. trifoliata); crossed by Joe Furr USDA-ARS in Indio, CA 1965; selected by D. Hutchison (USDA-ARS, Orlando, FL); tested as HRS-852; introd. 1999. Plant: medium; fruit sparse and sparsely seeded; seed polyembryonic, but with more than 50\% off-type seedlings. Rootstock traits: semi-dwarf tree, smaller than trees on Carrizo or Swingle; trees grafted with sweet orange are highly productive; freeze tolerance good; fruit size and quality are very good; high tolerance to $P$. nicotianae root rot, Florida citrus blight, and Florida isolates of $\mathrm{CTV}$; appears susceptible to damage from the $P$. palmivora/D. abbreviatus weevil complex in poorly drained soils; may be unacceptable on soils with high $\mathrm{pH}$ or salinity.

US-897. Citrus rootstock. Origin: USDA-ARS, Fort Pierce, FL, by K.D. Bowman. Cleopatra mandarin (C. reticulata) x Flying Dragon trifoliate orange ( $P$. trifoliata); tested as HRS-897 by D. Hutchison, H. Wutscher, and K. D. Bowman (USDA-ARS, Ft. Pierce, Florida); introd. 2007. Plant: medium; fruit numerous and seedy; seed polyembryonic and producing few off-type seedlings. Rootstock performance: dwarf, a little larger than trees on Flying Dragon; trees grafted with sweet orange, mandarin, and grapefruit are highly productive on a canopy volume basis; freeze tolerance moderate; fruit quality good, but fruit tends to be small; appears tolerant to $P$. nicotianae root rot, Florida isolates of CTV, and the P. palmivora/D. 
abbreviatus weevil complex in poorly drained soils; appears moderately susceptible to Florida citrus blight after 10 years of age; tolerance of calcareous soils and salinity not known.

US-942. Citrus rootstock. Origin: USDA-ARS Fort Pierce, FL by K.D. Bowman. Sunki mandarin $(C$. reticulata) x Flying Dragon trifoliate orange ( $P$. trifoliata); cross made by H. Barrett, USDAARS, Orlando, FL; tested as HRS-942 by D. Hutchison, H. Wutscher, and K.D. Bowman, USDA-ARS, Orlando, FL; introd. 2010. Plant: medium, fruit sparse and seedy, seed polyembryonic and producing few off-type seedlings. Rootstock performance: semi-dwarf, the size of trees on Swingle or somewhat smaller; trees grafted with sweet orange, mandarin, and grapefruit are highly productive; freeze tolerance is good; fruit size and quality are good; appears tolerant of $P$. nicotianae root rot, Florida citrus blight, and Florida isolates of CTV; appears somewhat susceptible to damage from the $P$. palmivora/D. abbreviatus weevil complex in poorly drained soils; tolerance to calcareous soils and salinity is not known.

\section{CRANBERRY}

Nicholi Vorsa, Department of Plant Biology and Pathology, Rutgers University, New Brunswick, NJ

BE4 (Willapa Red). Midseason cranberry, with high yield potential. Origin: USDA-ARS selection from 1930-1950 breeding program, tested further at Univ. Washington, Long Beach, WA by K. Patten. Putative Aviator x McFarlin; introd. 2009. Fruit: small, slightly over $1 \mathrm{~g}$ in WI and WA; shiny skin with little bloom; round; SS 7\%, less than Stevens in WA; total anthocyanin content over $60 \%$ greater than Stevens in WI; consistently low field and storage rot; potential for dry-harvest fresh fruit market. Plant: vigorous early growth and production; fine uprights with over 75\% annual fruiting setting 2-3 berries/upright; little runner production after fruiting; fruit set $60 \%$ with a tendency for partial self-pollination; good tolerance to wet soils; flowering phenology similar to Stevens.

CNJ97-105-4 (Mullica Queen ${ }^{\circledR}$ ). Midseason cranberry with very high production potential. Origin: Rutgers University, NJAES, Chatsworth, NJ, by N. Vorsa and J. Johnson-Cicalese. Lemunyon x No. 35; crossed 1997; selected 2000; introd. 2007. USPP 19,434; 11 Nov. 2008. Fruit: large, over 2 g in NJ, WI; shiny skin with little to no bloom; widely elliptic, with rounded to square stem end and rounded calyx end; total anthocyanins $15 \%$ higher than Stevens. Plant: vine stolons and uprights moderate coarse to coarse; vigorous stolon production; early flowering phenology (3-5 d before Stevens); supports high upright fruit load; appears less fruit-rot susceptible than Stevens.

\section{Crimson Queen ${ }^{\circledR}$. See NJS98-23.}

\section{Demoranville ${ }^{\circledR}$. See NJS98-35.}

Grygleski \#1. Early midseason maturing cranberry with high yield potential. Origin: Tomah, WI by E.J. Grygleski. Earl Rezin Native x Searles; crossed 1974; introd. 1994. Fruit: medium to large; high quality fresh fruit berry; high yield potential; total anthocyanins $12 \%$ higher than Stevens. Plant: vigorous vine; winter hardy; most widely cultivated of the Grygleski cultivars.

Grygleski \#2. Early midseason maturing cranberry with high yield potential. Origin: Tomah, WI by E.J. Grygleski. Earl Rezin Native x Searles; crossed 1974; introd. 1996. Fruit: medium to large; round; suitable for fresh fruit milling; moderate to high yield potential; total anthocyanins $12 \%$ higher than Stevens. Plant: vigorous vine; winter hardy; as vines mature they have a tendency to clump together forming an uneven canopy.

Grygleski \#3. Early midseason maturing cranberry. Origin: Tomah, WI by E.J. Grygleski. Earl Rezin Native x Searles; crossed 1974; introd. 2004. Fruit: medium; total anthocyanins 12\% higher than Stevens; yield has tendency to increase as bed matures; high yield potential. Plant: very vigorous vine; winter hardy.

HyRed. Early season cranberry with high fruit pigment concentration, early flowering, with high capacity for fruit bud formation on fruiting uprights. Origin: University of Wisconsin-Madison, Madison, WI, by E.L. Zeldin and B.H. McCown. Stevens x BL8 (D. Boone selection of an O.P. seedling of Ben Lear); crossed 1990; selected 1992; introd. 2003. USPP 14,225; 14 Oct. 2003. Fruit: 1.6$1.8 \mathrm{~g}$; elliptical blocky with squared stem end; early; anthocyanin content over $40 \mathrm{mg} / 100 \mathrm{~g}$ fruit in mid-September; homogeneous color with few low colored berries at harvest; titratable acidity and percent soluble solids similar to standard cultivars; tart pleasant flavor. Plant: medium to high yielding; moderately vigorous vine; sensitive to recurring poor drainage; high percentage of uprights holding 3-5 fruit, forming multiple overwintering flower buds leading to uniform annual flowering.

Mullica Queen ${ }^{\circledR}$. See CNJ97-105-4.

NJS98-23 (Crimson Queen ${ }^{\circledR}$ ). Early season, large-fruited, early high anthocyanin content, exceptional vegetative vigor, highly productive cranberry. Origin: Rutgers University, NJAES, Chatsworth, NJ, by N. Vorsa. Stevens x Ben Lear; crossed 1988; selected 1998, tested as NJS98-23; introd. 2006. USPP 18,252; 27 Nov. 2007. Fruit: large, over $1.9 \mathrm{~g}$ in NJ, WI; shiny with bloom around calyx end, otherwise little to no bloom; elliptic, with rounded to slightly pointed stem end, and rounded calyx end; total anthocyanins typically $50 \%$ greater than Stevens. Plant: vigorous stolon production; vines moderately coarse; early flowering phenology, 2-3 d before Stevens; fruit-rot susceptibility similar to Ben Lear.

NJS98-35 (Demoranville ${ }^{\circledR}$ ). Early season, large-fruited, early high anthocyanin content, and highly productive cranberry. Origin: Rutgers University, NJAES, Chatsworth, NJ, by N. Vorsa. Franklin x Ben Lear; crossed 1988; selected 1998; introd. 2007. USPP 18,911; 10 June 2008. Fruit: large, over 2 g in NJ, WI; shiny with bloom around calyx end, otherwise little to no bloom; elliptic, with rounded to slightly pointed stem end, and slightly protruding calyx; total anthocyanins typically 60\% higher than Stevens, lower titratable acidity than Stevens. Plant: moderately vigorous stolon production; uprights moderate coarseness; early flowering phenology, 1-2 d before Stevens; appears less fruit-rot susceptible than Ben Lear.

\section{GENIP (QUENEPA or SPANISH LIME)}

\section{Ricardo Goenaga, USDA-ARS, Tropical Agriculture Research Station, Mayaguez, PR}

Añasco. Tall tree producing clusters of 16-23 fruits. Origin: Clonal selection by Francisco Jordán, Añasco, PR. Parents unknown. Fruit: spherical; small, 10 g; SS 21\%; 62\% pulp; seed weight 2.3 g. Tree: tall; high yielding.

Sasa. Medium-sized tree producing clusters of 9-12 fruits. Origin: Clonal selection by Ismael Reyes-Soto, Juana Díaz, PR; parents unknown. Fruit: elliptical; c. 16 g; SS 24\%; 46\% pulp; seed weight $4.5 \mathrm{~g}$. Tree: foliage heavy; irregular bearing.

Sotomayor. Very tall tree producing small clusters of 2-6 fruits. Origin: Clonal selection by Ismael Reyes-Soto, Santa Isabel, PR; parents unknown. Fruit: ovoid; 14 g; juicy; SS 21\%; 55\% pulp; flavor excellent; seed weight $3 \mathrm{~g}$. Tree: vigorous; regular bearing.

\section{GRAPE}

Christopher L. Owens, USDA-ARS, Grape Genetics Research Unit, Geneva, NY 
A-2640 (Sweet Magic ${ }^{\mathrm{TM}}$ ). A medium-late, blue seedless table grape. Origin: University of Arkansas, by J.R. Clark, J.N. Moore, and D. Cain. Ark. 1925 x Ark. 2020; crossed 1992; selected 1996. USPP 20,745; 9 Feb. 2010. Fruit: blue; medium-large; oblong; seedless; non-slipskin, crisp; medium-firm; juicy; ripens $20 \mathrm{~d}$ after Thompson Seedless; mostly neutral sweet flavor; tendency to crack in rains near maturity. Cluster: 1,135 g; medium-loose density; conical. Vine: moderately vigorous to vigorous; very productive; hardy to $-15^{\circ} \mathrm{C}$.

Chisago. A cold hardy wine grape. Origin: Chisago City, MN by K. Peterson and K. Peterson. St. Croix x Swenson Red; USPP 19,246; 16 Sept. 2008. Fruit: black; 2-4 g; SS 17.1\%-19.6\%; pH 3.1-3.4; titratable acidity $0.90-1.29 \%$. Cluster: slightly conical; loose; $40-70$ berries. Vine: vigorous; hardy to $-40{ }^{\circ} \mathrm{C}$.

Delicious. A self-fertile, early black muscadine grape. Origin: Univ. of Florida, by D. Gray, Z. Li, S. Dhekney, D. Hopkins, and C. Sims. AA10-40 x CD8-81; selected 1993; introd. 2009. Fruit: black; oval; 10.2 g; ripens early; semi-crunchy; dry stem scar. Cluster: 3-15 berries. Vine: $12.8 \mathrm{~kg} / \mathrm{vine}$; highly resistant to ripe rot (Colletotrichum gloeosporioides), bitter rot (Greeneria uvicoa), and black rot (Guignardia bidwellii); Pierce's Disease (Xylella fastidiosa) has not been observed.

Eudora. A pistillate, purple muscadine grape. Origin: USDA-ARS, Poplarville, MS and Univ. of Florida, by S. Stringer, J. Spiers, D. Marshall, and D. Gray. Fry x Southland; selected 1981; introd. 2007. Fruit: purple; round; crisp; high concentration of ellagic acid in skins. Cluster: berries ripen uniformly; compact; suitable for cluster harvesting. Vine: resistant to fruit rots and Pierce's Disease.

IFG 31-077 (Sweet Surrender ${ }^{\mathrm{TM}}$ ). A black-fruited, early seedless table grape. Origin: International Fruit Genetics, LLC, Bakersfield, CA, by D. Cain. Summer Royal x Regal; crossed 2001; selected 2003; USPP 20,292; 15 Sept. 2009. Fruit: black; elongated ovate; $6.1 \mathrm{~g}$ when treated with gibberellic acid; rudimentary seeds. Cluster: $665 \mathrm{~g}$; conical; moderately dense. Vine: high vigor.

IFG 104-253 (Sweet Sunshine ${ }^{\mathrm{TM}}$ ). A white-fruited, midseason seedless table grape. Origin: International Fruit Genetics, LLC, Bakersfield, CA, by D. Cain. Princess x Regal; crossed 2001; selected 2003; USPP 20,377; 6 Oct. 2009. Fruit: white; elliptic; $8.2 \mathrm{~g}$ when treated with gibberellic acid; rudimentary seeds. Cluster: $1,075 \mathrm{~g}$; conical. Vine: medium vigor.

Jinok. A black, seeded table grape. Origin: National Horticultural Research Institute, Republic of South Korea, by Hae Keun Yun, Kyo Sun Park, Jeong Ho Roh, Yong Bum Kwack, Ji Hae Jun, Seok Tae Jeong, Seung Hui Kim, Han Ik Jang, and Yong Uk Shin. Delaware x Campbell Early; crossed 1983; selected 1997; tested as Wonkyo RA12; introd. 2004. Fruit: black; round to slightly ovate; $6.0 \mathrm{~g}$; early; slip-skin; pronounced foxy aroma; 2-4, 6.2 mm seeds. Cluster: 320380 g with 55-64 berries; conical and occasionally shouldered; compact with low incidence of shattering. Vine: Own-rooted vines are vigorous and show no bud damage at $-20^{\circ} \mathrm{C}$; resistant to bunch rots, moderately resistant to anthracnose (Elsinoe ampelina) and resistant to downy mildew (Plasmopara viticola).

Majesty. A large, pistillate, red-black muscadine grape. Origin: Florida A\&M University, Tallahassee, FL, by J. Lu, Z. Ren, and X. $\mathrm{Xu}$. AA10-40 x CD8-81; tested as O26-5-8; selected 2001; introd. 2009. Fruit: red-black; round; $16.5 \mathrm{~g}$; flesh firm. Cluster: 6-10 berries/cluster. Vine: highly disease resistant.

Souk. A tetraploid, seeded table grape. Origin: National Horticultural Research Institute, Republic of South Korea, by H.K. Yun, K.S. Park, J.H. Roh, Y.B. Kwack, J.H. Jun, S.T. Jeong, S.H. Kim, H.I. Jang, and Y.U. Shin. Kyoho x Beniizu; crossed 1992; selected 2000; tested as Wonkyo RA-18; introd. 2004. Fruit: black-blue; slightly ovate; $10.9 \mathrm{~g}$; late; pronounced foxy aroma; presence of $2-4,8.0 \mathrm{~mm}$ seeds. Cluster: $400-450 \mathrm{~g}$ with $35-40$ berries; conical and occasionally shouldered; compact with no shattering. Vine: tetraploid, own-rooted vines are vigorous; yield $20 \mathrm{Mt} / \mathrm{ha}$; 40-50\% bud survival at $-20{ }^{\circ} \mathrm{C}$

Southern Jewel. A self-fertile black muscadine grape with fruit produced in bunches. Origin: Univ. of Florida, by D. Gray, Z. Li, S Dhekney, D. Hopkins, and C. Sims. Granny Val x DB-63; selected 1994; introd. 2009. Fruit: black; round; $11.0 \mathrm{~g}$; ripens early; crunchy. Cluster: $6-12$ berries that strongly adhere to the peduncle. Vine: yield $10.3 \mathrm{~kg} /$ vine; resistant to ripe rot, bitter rot, and black rot.

Sugrathirtyfive. A green, late, seedless table grape Origin: Sun World International, LLC, Bakersfield, CA, by M. Striem. 97148027-365 x 99080-126-251; crossed 2004; selected 2006; USPP 20,491; 17 Nov. 2009. Fruit: green; elliptic; 6.8 g untreated; ripens late, 7 weeks after Sugraone; rudimentary seeds. Cluster: 442 g; conical. Vine: Vigorous; yield $12.2 \mathrm{~kg} /$ vine.

Sugrathirtyfour. A dark-red, late, seedless table grape. Origin: Sun World International, LLC, Bakersfield, CA, by D. Cain and M. Striem. 91171-094-493 x 92167-052-375; crossed 1999; selected 2003; USPP 19,750; 17 Feb. 2009. Fruit: dark-red; round; 9.1 g untreated; late, 10-14 days after Autumn Royal; rudimentary seeds. Cluster: 572 g; conical. Vine: Vigorous; yield 14 kg/vine.

Sugrathirtyone. A green, late, seedless table grape. Origin: Sun World International, LLC, Bakersfield, CA, by D. Cain and M. Striem. 92147-050-238 x 92187-055-030; crossed 1999; selected 2001; USPP 19,065; 5 Aug. 2008. Fruit: green; elliptic; $4.5 \mathrm{~g}$ untreated, 7.2-8.7 g treated with gibberellic acid; late, 6-8 weeks after Sugraone; rudimentary seeds. Cluster: $367 \mathrm{~g}$; conical. Vine: medium to weak vigor; yield $11.7 \mathrm{~kg} / \mathrm{vine}$.

Sugrathirtythree. A green, late, seedless table grape. Origin: Sun World International, LLC, Bakersfield, CA, by D. Cain and M. Striem. 92147-050-238 x 92187-055-030; crossed 1999; selected 2001; USPP 19,008; 8 July 2008. Fruit: green; elliptic; $4.5 \mathrm{~g}$ untreated; late, 7-9 weeks after Sugraone; rudimentary seeds. Cluster: 203 g; conical. Vine: Medium to weak vigor; yield 4.47 $\mathrm{kg} / \mathrm{vine}$.

Sugrathirtytwo. A red, aromatic, midseason seedless table grape Origin: Sun World International, LLC, Bakersfield, CA, by D. Cain and M. Striem. 88124-037-243 x 88047-004-226; crossed 1994; selected 1998; USPP 19,024; 15 July 2008. Fruit: red; elliptic; 3.9 g untreated; ripens with Flame Seedless; rudimentary seeds. Cluster: 748 g; loose; cylindrical. Vine: Vigorous; yield 11.9 kg/vine.

Sweet Magic ${ }^{\mathrm{TM}}$ see A-2640.

Sweet Sunshine $^{\mathrm{TM}}$ see IFG 104-253.

Sweet Surrender ${ }^{\mathrm{TM}}$ see IFG 31-077.

\section{GRAPE ROOTSTOCK}

Christopher L. Owens, USDA-ARS, Grape Genetics Research Unit, Geneva, NY

8909-05 (UCD GRN-1 ${ }^{\mathrm{TM}}$ ). A nematode resistant rootstock for grape. Origin: University of California, Davis, by A. Walker; Vitis rupestris A. de Serres x Muscadinia rotundifolia Cowart; introd. 2008; USPP 19,981; 12 May 2009. Plant: hermaphroditic, sterile flowers; $2 \mathrm{n}=39 ; 80 \%$ success rate of rooting and grafting hardwood cuttings; moderately long shoots; shorter internodes than most rootstocks. Rootstock performance: resistant to root-knot (Meloidogyne incognita), dagger (Xiphinema index), citrus (Tylenehulus 
sernipenetrans), lesion (Pratylenchus vulnus), and ring nematodes (Mesocriconema xenoplax); resistant to grape phylloxera (Daktulosphaira vitifoliae).

9363-16 (UCD GRN-2 ${ }^{\mathrm{TM}}$ ). A nematode resistant rootstock for grape. Origin: University of California, Davis, by A. Walker; L514-30 ( $V$. rufotomentosa $\mathrm{x}$ ( $V$. champinii Dog Ridge $\mathrm{x} V$. riparia Riparia Gloire)) x V. riparia Riparia Gloire; introd. 2008; USPP 19,993; 12 May 2009. Plant: staminate; roots and grafts easily; long shoots and internodes. Rootstock performance: resistant to root-knot, lesion, and dagger nematodes, moderate resistance to citrus nematode and susceptible to ring nematode; resistant to grape phylloxera.

9365-43 (UCD GRN-3 ${ }^{\text {TM}}$ ). A nematode resistant rootstock for grape. Origin: University of California, Davis, by A. Walker; L514-30 ( $\mathrm{V}$. rufotomentosa x ( $V$. champinii Dog Ridge x $V$. riparia Riparia Gloire)) x $V$. champinii c9038; introd. 2008; USPP 20,051; 2 June 2009. Plant: pistillate; long, straight canes with moderately long internodes and a moderate number of lateral shoots. Rootstock performance: resistant to root-knot, dagger, citrus, and lesion nematodes; susceptible to ring nematode; resistant to phylloxera.

9365-85 (UCD GRN-4 ${ }^{\mathrm{TM}}$ ). A nematode resistant rootstock for grape. Origin: University of California, Davis, by A. Walker; L514-30 ( $V$. rufotomentosa x ( $V$. champinii Dog Ridge $\mathrm{x} V$. riparia Riparia Gloire)) x V. champinii c9038; introd. 2008. Plant: staminate; long, straight canes with moderately long internodes and a moderate number of lateral shoots. Rootstock performance: resistant to rootknot, dagger, citrus, and lesion nematodes; susceptible to ring nematode; resistant to phylloxera.

9407-14 (UCD GRN-5 ${ }^{\mathrm{TM}}$ ). A nematode resistant rootstock for grape. Origin: University of California, Davis, by A. Walker; L6-1 (Ramsey x V. riparia Riparia Gloire) x $V$. champinii c9021; introd. 2008. Plant: staminate; weak mother vine; long internodes and canes; few lateral shoots. Rootstock performance: resistant to rootknot, dagger, citrus, and lesion nematodes; moderate resistance to ring nematode; resistant to phylloxera.

UCD GRN-1 ${ }^{\mathrm{TM}}$. See 8909-05.

UCD GRN-2 ${ }^{\text {TM }}$. See 9363-16.

UCD GRN-3 ${ }^{\mathrm{TM}}$. See 9365-43.

UCD GRN-4 ${ }^{\mathrm{TM}}$. See 9365-85.

UCD GRN-5 ${ }^{\mathrm{TM}}$. See 9407-14.

\section{MACADAMIA}

Craig M. Hardner, University of Queensland, School of Land, Crop and Food Sciences, St. Lucia, Queensland, Australia

A268. Intermediate to large, high-yielding tree producing attractive kernels. Origin: Hidden Valley Plantations, Beerwah, Queensland, by H. Bell and D. Bell. Kau O.P.; selected 1981; introd. 1997. Nut: bearing habit mainly in singles; large; round; intermediate flecking, very small micropyle and slightly rough surface; kernel recovery intermediate; kernel full, creamy white. Tree: intermediate to large; spreading; canopy intermediate to open; leaves long, 20-25 cm, with pointed apex, margins spiny, undulating towards apex, short petiole; flowering midseason, condensed.

Daddow. Old, hardy Australian cultivar with very dense canopy, intermediate to large tree, producing intermediate-size kernels. Origin: Maryborough, Queensland, Australia, by R. Misfield and N. Greber. Parentage unknown; selected 1950s. Nut: bearing habit in triplets or fours, avg. three; intermediate; round; tea-colored with heavy striping; very small micropyle; distinct suture line and large hilum; kernel recovery intermediate, 34\%; kernel intermediate, $2.4 \mathrm{~g}$, round with distinct ridge; percentage of whole kernels intermediate, $48 \%$. Tree: intermediate to large, spreading to upright; canopy very dense; leaves intermediate in length, 15-20 cm wide, light (young) to dark (old), with obtuse apex, moderately spiny and undulating margins, and intermediate petiole length; flowering midto late-season; fruit abscission extended, late-season; yield intermediate; slightly susceptible to nut borer.

HAES 814: Intermediate very precocious upright tree with open canopy and producing good yields of small kernels. Origin: Hawaii Agricultural Experiment Station, Hilo, HI, by P. Ito and R. Hamilton. Honokaa Special x O.P.; selected c. 1969. Nut: bearing habit in small bunches, avg. five per raceme; small, $5 \mathrm{~g}$; round; slight flecking; intermediate micropyle and intermediate size hilum; kernel recovery intermediate, $38 \%$; kernel small, round, cream to off-white; percentage of whole kernels intermediate, $46 \%$. Tree: small to intermediate; upright; canopy intermediate to open; leaves long, $20-25 \mathrm{~cm}$, wide, dull green, with small apex, slightly spiny and undulating margins, medium petiole length; very precocious; racemes long, 20-25 cm; flowering early-intermediate, short; fruit abscission mid- to lateseason; yield intermediate.

HAES 816. Intermediate to large, moderately spreading, precocious tree producing large kernels. Origin: Hawaii Agricultural Experiment Station, Hilo, HI, by P. Ito and R. Hamilton. Rickard O.P.; selected c. 1969. Nut: bearing habit in singles to few, avg. five per raceme; intermediate to large; round; pale; with slight flecking, small to intermediate micropyle and distinct suture line; kernel recovery intermediate, 39\%; kernel large, 2.9-3.4 g, round, variable in color; percentage of whole kernels high, $62 \%$. Tree: intermediate to large, moderately upright to upright; canopy intermediate to dense; leaves intermediate in length, $15-20 \mathrm{~cm}$, intermediate in width, pale lime green, with obtuse apex, spineless, slightly undulating margin, long petiole; precocious; racemes long, $20-25 \mathrm{~cm}$; flowering early, intermediate in length; fruit abscission early to midseason; yield low; highly susceptible to tropical nut borer, southern stink bug and stick-tights; not very susceptible to koa seedworm (Cryptophelbia illepida).

HAES 842: Intermediate to large, moderately upright precocious tree producing small kernels. Origin: Hawaii Agricultural Experiment Station, Hilo, HI, by P. Ito and R. Hamilton. Keauhou O.P., selected c. 1971; not commercially introd. in Hawaii. Nut: bearing habit in singles to triplets, avg. three per raceme; small; slightly oval; light brown; slight flecking; small to intermediate micropyle; kernel recovery intermediate; kernel small to intermediate, $2.9 \mathrm{~g}$, round, variable colored; percentage of whole kernels intermediate. Tree: intermediate to large; moderately upright; canopy open, becoming denser with age; leaves long, 20-25 cm, very wide, light green with obtuse apex, spiny and undulating margins, and long petiole; precocious; flowering early, long; fruit abscission extended, midto late-season; yield intermediate; fruit susceptible to pregermination on tree.

HAES 849. Intermediate to large spreading tree producing intermediate-size kernels. Origin: Hawaii Agricultural Experiment Station, Hilo, HI, by P. Ito and R. Hamilton. Keauhou O.P.; selected c. 1973; not commercially introd. in Hawaii. Nut: bearing habit in bunches, avg. nine per raceme; intermediate to large; round; slight to moderate flecking; intermediate micropyle; kernel recovery intermediate, 39\%; kernel intermediate, $2.8 \mathrm{~g}$, slightly flattened, dull cream; percentage of whole kernels high. Tree: intermediate to large; spreading; canopy intermediate to dense; leaves long, 20-25 $\mathrm{cm}$, wide, dark green, with obtuse apex, spiny undulating margins, and petiole of intermediate length; racemes intermediate in length, $18-22 \mathrm{~cm}$; flowering short, intermediate- to late-season; fruit abscission extended, mid- to late-season; yield low to intermediate; 
low-medium susceptibility to stick-tights; fruit susceptible to pregermination on tree.

Hidden Valley A4. Very precocious, small to intermediate tree producing fruit with high kernel recovery and attractive kernels. Origin: Hidden Valley Plantations, Beerwah, Queensland, Australia, by H. Bell and D. Bell. Renown (Macadamia integrifolia) $\mathrm{x}$ Own Choice (M. tetraphylla), as determined with genetic markers; crossed 1976; selected 1980; introd. 1988; Australian PBR 88/001, 1988. Nut: bearing habit mainly in singles, avg. two per raceme; large, $7 \mathrm{~g}$; round, slightly pointed at micropyle; moderate flecking and small micropyle; kernel recovery high, 42\%; kernel large, $3.2 \mathrm{~g}$, flattened, white-cream, attractive; percentage of whole kernel intermediate, $50 \%$. Tree: small to intermediate, spreading to rounded; canopy intermediate to open; abnormal vertical growth (AVG) disorder susceptibility low; racemes very precocious, long, 25-30 $\mathrm{cm}$; flowering late, condensed, heavy; fruit abscission midseason; yield low; highly susceptible to tropical nut borer (Hypothenemus obscurus) and southern stinkbug (Nezara viridula); very highly susceptible to stick-tights (nuts that don't drop when mature).

Hidden Valley A16. Upright, late-dropping tree with dense canopy producing fruit with intermediate to large attractive kernels. Origin: Hidden Valley Plantations, Beerwah, Queensland, by H. Bell and D. Bell. Renown (M. integrifolia) x Own Choice (M. tetraphylla), as determined with genetic markers; crossed 1977; selected 1981; introd. 1988; Australian PBR 88/002, 1988. Nut: bearing habit in open bunches, avg. five per raceme; nut variable (small-large); oval; moderate flecking; very small micropyle and raised hilum; kernel recovery intermediate, $38 \%$; kernel intermediate to large, $2.9 \mathrm{~g}$, full, uniform white, attractive; percentage of whole kernel high, $60 \%$. Tree: small to intermediate; upright; canopy dense to intermediate, with long willowing branches; AVG disorder susceptibility low; racemes long, $20-25 \mathrm{~cm}$; flowering late, condensed; fruit abscission late-season; yield low; moderately susceptible to tropical nut borer and southern stinkbug; susceptible to stick-tights.

Hidden Valley A38. Very upright and open tree producing fruit in large bunches. Origin: Hidden Valley Plantations, Beerwah, Queensland, by H. Bell and D. Bell. Own Choice O.P.; crossed c. 1975; selected 1981; introd. 1992. Australian PBR 92/179, 1994. Nut: bearing habit in tight bunches, up to 30 per raceme; intermediate to large; round; light brown, with slight flecking; very small micropyle, and suture line often present; kernel recovery intermediate; kernel slightly flattened; percentage of whole kernels high. Tree: intermediate; very upright; canopy very open with willowing branches; racemes very long $(>30 \mathrm{~cm})$; flowering midseason, condensed; highly susceptible to stick-tights.

Own Venture. Intermediate to large, moderately upright tree, producing large, variable-shaped kernels. Origin: Amamoor, Queensland, by N. Greber. Own Choice O.P. Nut: bearing habit in small bunches, avg. four per raceme; large, $8 \mathrm{~g}$; heavy flecking; large micropyle; kernel recovery intermediate, 35\%; kernel large, $2.9 \mathrm{~g}$, variable shaped; percentage of whole kernels low, 35\%. Tree: intermediate to large; moderately upright; canopy variable in density; leaves long, $20-25 \mathrm{~cm}$, narrow to intermediate in width, dull light green; racemes long, 20-25 cm; flowering short, lateseason; yield intermediate; susceptible to stick-tights.

\section{MANGO}

\section{Richard J. Campbell, Fairchild Tropical Botanic Garden, Coral} Gables, FL

Angie. A monoembryonic mango cultivar for home and commercial use, with good production and postharvest quality. Origin: Fairchild Tropical Botanic Garden, Coral Gables, FL., by R. Campbell. Parentage unknown; selected c. 1993; introd. 2008. Fruit: length $11 \mathrm{~cm}$, breadth $8 \mathrm{~cm}$, thickness $7 \mathrm{~cm} ; 380-420 \mathrm{~g}$; skin orange-yellow, with pink to red blush, numerous small yellow and white dots, thin, tender, adherent; oblong with flattened base and slender stem inserted obliquely in shallow cavity; apex bluntly pointed with no beak; surface undulating; flesh orange, firm, melting, juicy, with no fiber; flavor rich and sweet with a weak pleasant aroma; quality excellent; stone medium thick and woody; seed monoembryonic, filling $40 \%$ of stone; ripens June to July in southern Florida; postharvest characteristics excellent. Tree: semi-dwarf.

B74 (Calypso ${ }^{\mathrm{TM}}$ ). A commercial mango cultivar with flavor similar to Kensington, but better yield, ripe fruit skin color, and resistance to fruit rots. Origin: Queensland Department of Primary Industries, Brisbane, Australia, by A.W. Whiley and J.W. Dorrian. Sensation X Kensington. USPP 17,770; 5 May 2007. Fruit: length $10 \mathrm{~cm}$, breadth $9 \mathrm{~cm}$, thickness $7 \mathrm{~cm} ; 420-490 \mathrm{~g}$; skin yellow, with red and crimson blush, thin, tender, easily separating; ovate with a flattened base, medium stem inserted obliquely; apex rounded with no beak; surface smooth; flesh yellow, soft, tender, juicy, with no fiber; flavor mild and sweet with a weak pleasant aroma; quality good; stone thick and woody; seed monoembryonic; ripens June to July in southern Florida; postharvest life and storage characteristics excellent. Tree: vigor low to moderate; tolerant to flower and fruit diseases.

\section{Calypso $^{\mathrm{TM}}$. See B74.}

Jean Ellen. Early polyembryonic mango cultivar for home use with good eating quality. Origin: Fairchild Tropical Botanic Garden, Coral Gables, FL., by R. Campbell. Parentage unknown; selected 1997; introd. 2008. Fruit: length $12 \mathrm{~cm}$, breadth $5.5 \mathrm{~cm}$, thickness $5 \mathrm{~cm}$; 170-240 g; skin orange-yellow, no blush, numerous small yellow and white dots, thin, tough, adherent; long and slender, slightly sigmoid with a flattened base, slender stem inserted squarely in shallow, grooved cavity; apex pointed with a small lateral beak; surface undulating; flesh yellow, soft, melting, juicy, with medium, coarse fiber; flavor rich, spicy and sweet with a weak pleasant aroma; quality good; stone thick and woody; seed polyembryonic, filling $60 \%$ of stone; ripens April to June in southern Florida. Tree: moderately vigorous; highly tolerant to leaf, bloom and fruit diseases.

Phimsen Man. Traditional Thai mango cultivar, often eaten at mature green stage. Origin: Northern Thailand. Parentage unknown. Fruit: length $13 \mathrm{~cm}$, breadth $8 \mathrm{~cm}$, thickness $7 \mathrm{~cm}$; 380-490 g; skin yellow, with slight pink blush, no dots, thin, tender, adherent; long and slender, sigmoid with a slightly rounded base, slender stem inserted squarely; apex rounded with large lateral beak; surface smooth; flesh yellow, soft, juicy, with no fiber; flavor rich, spicy and sweet with a weak pleasant aroma; quality excellent; stone mediumthin, papery; seed polyembryonic, filling $80 \%$ of stone; ripens May to June in southern Florida. Tree: vigorous; highly tolerant to fungal diseases; shy bearing.

Shelly. A monoembryonic cultivar for commercial use. Origin: Volcani Center, Bet Dagan, Israel. Tommy Atkins x Keitt; introd. to Florida 1999. Fruit: 450-520 g; skin orange-yellow, with red to orange blush, thick, tough, adherent; oblong; flesh yellow, soft, juicy, with no fiber; flavor mild and sweet with a weak pleasant aroma; quality good; stone thick and tough; seed monoembryonic; ripens June to July in Southern Florida; shelf life excellent. Tree: vigorous; highly tolerant to leaf, bloom and fruit diseases.

Tango. A monoembryonic cultivar for commercial use. Origin: Volcani Center, Bet Dagan, Israel. Seedling of 16/36; introd. to Florida 1999. Fruit: 250-780 g; skin orange-yellow, with red to orange blush, thick, tough and adherent; oblong; flesh yellow, soft, and juicy, with no fiber; flavor mild and sweet with a weak pleasant aroma; quality good; stone thick and tough; seed monoembryonic; ripens May to June in southern Florida. Tree: vigorous; highly productive. 


\section{NECTARINE}

Ksenija Gasic, Department of Environmental Horticulture, Clemson University, Clemson, SC

W.R. Okie, USDA-ARS, Southeastern Fruit and Tree Nut Research Laboratory, Byron, GA

Alice-col. Yellow-fleshed, midseason, clingstone, pillar nectarine. Origin: CRA-Unità di Ricerca per la Frutticoltura di Forlì, Italy, by A. Liverani; (Pegaso x Pillar) x (Venus x Pillar). Fruit: large; round to slightly oblong, medium uniform; bright red overcolor covers 90 $100 \%$ of yellow-green ground color; flesh yellow, firm, dense, nonmelting; good flavor, balanced sugars and acid; ripens 13 July in Forli, 3 d before Redhaven. Tree: medium; columnar; vigorous; dense; moderately productive; flowers showy; leaf glands reniform.

Alitop. Yellow-fleshed, sub-acid, midseason, freestone nectarine. Origin: CRA-Unità di Ricerca per la Frutticoltura di Forlì, Italy, by A. Liverani. Big Top x (Flavortop x Snow Queen). CPVO patent application No. 20061134; 18 May 2006. Fruit: very large; round to slightly oblong, medium uniform; dark red overcolor covers almost $100 \%$ of yellow-green ground color; flesh yellow; very firm, very dense, crisp, melting; very good flavor, sub-acid; ripens 21 July in Forli, $6 \mathrm{~d}$ after Redhaven. Tree: medium; spreading; vigorous; dense; productive; flowers showy; leaf glands reniform.

ARC NE-1. Yellow-fleshed, melting, midseason, freestone nectarine suitable for drying. Origin: ARC Infruitec-Nietvoorbij, South Africa, by J. H. Acker. Parentage unknown; introd. 2007. Fruit: medium to large; round, uniform; bright yellow ground color with no red overcolor; flesh yellow, melting; sweet, mildly acidic; ripens 3$4^{\text {th }}$ week of December on Bien Donné, Stellenbosch, South Africa. Tree: medium; strong vigor; semi-upright; very productive; flowers non-showy, medium, self-fertile, pink; chilling requirement 400-600 h (Infruitec Units); leaf glands reniform.

ARC NE-2. Yellow-fleshed, melting, mid- to late-season, freestone nectarine, suitable for drying. Origin: ARC Infruitec-Nietvoorbij, South Africa, by J.H. Acker. Parentage unknown; introd. 2007. Fruit: small-medium; ovate, uniform; yellow ground color with no red overcolor; flesh yellow; melting, sweet, mildly acidic; ripens 2 $3^{\text {rd }}$ week of January on Bien Donné, Stellenbosch, South Africa. Tree: large; strong vigor; spreading; productive; flowers showy, self-fertile, pink; chilling requirement 400-600 h (Infruitec Units); leaf glands reniform.

ARC NE-8. Yellow-fleshed, melting, late-season, freestone nectarine suitable for drying. Origin: ARC Infruitec-Nietvoorbij, South Africa by J.H. Acker. Parentage unknown; introd. 2009. Fruit: large; ovate, uniform; yellow ground color; flesh yellow; melting; very sweet, mildly acidic; ripens week 4-5 on Bien Donné, Stellenbosch, South Africa. Tree: medium; vigorous; semi spreading; productive; flowers showy, self-fertile, light pink; chilling requirement 400-600 h (Infruitec Units); leaf glands reniform.

August Lion III. Yellow-fleshed, late-season, clingstone nectarine. Origin: Selma, CA by D.M. Serimian and L.M. Serimian. Summer Lion II x August Lion II; USPP 18,936; 17 June 2008. Fruit: large; ovate, uniform; red overcolor covering 90-100\% ground color; flesh yellow with reddish flecks and streaks at pit cavity; firm; very aromatic; ripens 15-30 Aug. in San Joaquin Valley, CA, 5-7 d later than August Lion II. Tree: medium; vigorous; upright and spreading; flowers showy, self-fertile; leaf glands reniform.

Autumn Bright. Yellow-fleshed, late-season, clingstone nectarine. Origin: Le Grand, CA by L.G. Bradford. September Bright x O.P.; USPP 18,751; 22 Apr. 2008. Fruit: large; globose to slightly oblong, uniform; deep red streaking and mottling overcolor covering reddish orange ground color with little yellow freckling on the sides towards apex; flesh yellow with deep red streaking next to the stone; firm, juicy; acidic and sweet; ripens 12-20 Sept. in San Joaquin Valley, CA. Tree: medium; spreading and dense; chilling requirement $650 \mathrm{~h}$; leaf glands large, reniform.

Burnectwentytwo. White-fleshed, non-melting, sub-acid clingstone nectarine. Origin: The Burchell Nursery Inc., Oakdale, CA, by J.K. Slaughter and T.J. Gerdts. Crimson Baby x Arctic Star; tested as E45.004; USPP18,293; 11 Dec. 2007. Fruit: large, 208 g; globose, uniform; medium red-dark red overcolor covering $75-95 \%$ of light yellow ground color; flesh pale white; firm, dense, non-melting; sweet and sub-acid; excellent keeping quality; ripens between May 25 and June 4 in San Joaquin Valley, CA. Tree: medium-large; vigorous; upright and medium dense; flowers large, showy, selffertile, light-medium pink; chilling requirement $550 \mathrm{~h}$; leaf glands small, reniform.

Candysweet V. Yellow-fleshed, sub-acid, clingstone nectarine. Origin: Le Grand, CA by L.G. Bradford. Spring Bright x Ruby Sweet; USPP 18,701; 22 Apr. 2008. Fruit: medium; globose, uniform; full red skin color with light orange yellow freckling toward the apex; flesh yellow with red freckling near the skin at maturity; firm, melting; sub-acid and very sweet; ripens 18-28 June in San Joaquin Valley, CA. Tree: large; vigorous; flowers showy; very large, self-fertile; leaf glands medium, reniform.

Candysweet $\mathbf{X}$. Yellow-fleshed, melting, sub-acid, clingstone nectarine. Origin: Le Grand, CA by L.G. Bradford. Ruby Diamond x Candy White; USPP 19,914; 14 Apr. 2009. Fruit: large; globose; mostly red overcolor; flesh yellow, firm, melting; sub-acid and sweet; ripens late June in San Joaquin Valley, CA. Tree: medium; vigorous; spreading and dense; flowers showy; self-fertile; chilling requirement $550 \mathrm{~h}$; leaf glands reniform.

Cascade. Yellow-fleshed, sub-acid, freestone nectarine. Origin: Modesto, CA, by G.N. Zaiger, L.M. Gardner, and G.G. Zaiger. 32RB351 x Honey Royale; USPP 18,369; 25 Dec. 2007. Fruit: large; globose; red blush covers $90 \%$ of surface over yellow ground color; firm; flesh yellow; sub-acid sweet; ripens 5-11 Aug. in Modesto, CA. Tree: large; vigorous; upright; flowers showy, large, self-fertile; leaf glands large, reniform.

\section{Colorburst $^{\mathrm{TM}}$. See ARC NE-8.}

Concettina. White-fleshed, midseason, saucer-shaped nectarine. Origin: Università Politecnica delle Marche -SAPROV (Italy), by B. Mezzetti, F. Capocasa, and S. Concetti. Natural mutation of Stark Saturn. EU PVR applied for. Fruit: large, 100-110 g; circumference 200-210 mm; uniform; flat; round, symmetric; glossy red covers 90$100 \%$ of surface over white-green ground color; flesh white; firm, juicy; high flavor, sweet, SS $14.2 \%$, and low-acid; titratable acidity, $52.5 \mathrm{meq} \mathrm{NaOH} / 1$; ripens 7 July in Ancona, Italy, $3 \mathrm{~d}$ after Zaitabo. Tree: medium-large; moderately vigorous; semi-upright; medium dense; very productive; flowers showy, pale-pink; leaf glands small, reniform.

Donutnice. White-fleshed, saucer-shaped, melting, semi-clingstone nectarine. Origin: S.A.R.L. Argo Selection Fruits, Elne, France, by A. Maillard and L. Maillard; Maillarflat O.P.; tested as 02.07.19 NBASF 0283; USPP 19,378; 28 Oct. 2008. Fruit: large to very large; broad oblate, uniform; red blush covers $90-100 \%$ of surface over pink-washed red ground color; flesh white with red pigmentation; very firm, very dense, juicy; balanced taste; ripens 25 July-3 Aug., 4 $\mathrm{d}$ before Maillarflat in Elne, France. Tree: medium-large; vigorous; flowers showy, self-fertile; leaf glands small, reniform.

Early Glo. Yellow-fleshed, melting, early-season, clingstone nectarine. Origin: ARC Infruitec-Nietvoorbij, South Africa, by J.H Acker. Parentage unknown; introd. 2009. Fruit: medium; round, in 
warm areas slight point, uniform; red overcolor covering $90 \%$ of yellow ground color; flesh yellow, firm, melting; medium sweet, mildly acidic; ripens $2^{\text {nd }}$ week of November on Bien Donné, Stellenbosch, South Africa. Tree: medium; vigorous; semi-upright; productive; flowers non-showy, self-fertile, medium-pink; chilling requirement 200-400 h (Infruitec Units); leaf glands reniform.

Honey May. Yellow-fleshed, early season clingstone nectarine. Origin: Modesto, CA, by G.N. Zaiger, L.M. Gardner, and G.G. Zaiger. 212LK80 x 7LL208; USPP 19,363; 21 Oct. 2008. Fruit: large; globose; red blush covers $90 \%$ of surface over yellow ground color; firm; holds firm on tree for 8-10 d after maturity; flesh yellow; balanced taste; ripens 1-7 May in Modesto, CA. Tree: large; vigorous; upright; flowers showy, self-fertile; chilling requirement $200 \mathrm{~h}$; leaf glands medium-large, reniform.

July Bright. Yellow-fleshed, crisp clingstone nectarine. Origin: Le Grand, CA, by L.G. Bradford. Ruby Diamond x Fire Sweet; USPP 18,703; 1 Apr. 2008. Fruit: large; globose, uniform; very deep red overcolor covering strong reddish orange ground color with moderate yellow freckling toward the apex; yellow flesh with red bleeding toward the skin and near the stone; firm, crisp, melting; mildly acidic and sweet; ripens 27 July to 7 Aug. in San Joaquin Valley, CA. Tree: large; vigorous; spreading and dense; flowers small, nonshowy, self-fertile; chilling requirement 650 h; leaf glands medium, reniform.

June Bright. Yellow-fleshed, clingstone nectarine. Origin: Le Grand, CA, by L.G. Bradford. Diamond Princess x Rose Diamond; USPP 18,708; 1 Apr. 2008. Fruit: large; uniform; globose; full dark red skin color with moderate light yellow freckling toward the apex; yellow flesh with slight red freckling next to the skin; firm, crisp, melting; mildly acidic and sweet; ripens 14-23 June in San Joaquin Valley, CA. Tree: medium; vigorous; flowers large, showy, selffertile; chilling requirement $700 \mathrm{~h}$; leaf glands medium, reniform.

June Sweet. Yellow-fleshed, sub-acid, mid-chill, clingstone nectarine. Origin: Le Grand, CA by L.G. Bradford; Kay Sweet O.P.; USPP 18,752; 22 Apr. 2008. Fruit: large; globose to oblong, uniform; full red skin color with slightly moderate yellow freckling towards the apex; flesh light yellow with red freckling near the stone at maturity; firm; sub-acidic and sweet; ripens 21 June to 4 July in San Joaquin Valley, CA. Tree: large; vigorous; upright and dense; flowers showy; self-fertile; chilling requirement $500 \mathrm{~h}$; leaf glands medium, reniform.

Kay Diamond V. Yellow-fleshed, clingstone nectarine. Origin: Le Grand, CA, by L.G. Bradford. Parentage unknown; USPP 18,772; 29 Apr. 2008. Fruit: large; globose, uniform; deep red overcolor over a deep reddish-orange ground color with much light orange-yellow freckling toward the apex; brilliant yellow flesh with red freckling next to the skin with further maturity; firm, crisp, melting; acidic and sweet; ripens 2-12 June in San Joaquin Valley, CA. Tree: medium; vigorous; upright and dense; flowers showy, self-fertile; chilling requirement $700 \mathrm{~h}$; leaf glands medium, globose.

Kay Diamond VII. Yellow-fleshed, mid-chill, clingstone nectarine. Origin: Le Grand, CA by L.G. Bradford. Parentage unknown; USPP 18,$715 ; 8$ Apr. 2008. Fruit: large; globose to slightly oblong, uniform; deep red overcolor covering reddish-orange ground color with slight orange-yellow freckling towards apex; yellow flesh with minimal moderate red flecking; firm, crisp, melting, juicy; acidic and sweet; ripens 6 June to 14 July in San Joaquin Valley, CA. Tree: large; vigorous; spreading and dense; flowers very large, showy, selffertile; chilling requirement $500 \mathrm{~h}$; leaf glands absent.

Majestic Pearl. White-fleshed, melting, sub-acid, clingstone nectarine. Origin: Le Grand, CA, by L.G. Bradford. 5P452 O.P.; USPP 18,778; 29 Apr. 2008. Fruit: large; globose, uniform; very deep red over a moderate red ground color, small amount of pale greenish yellow area where sun protected and moderate light orange-yellow freckling toward the apex; greenish-white flesh with very red streaking next to the stone, very firm, crisp, melting; sub acid and sweet; ripens 23 July to 3 Aug. in San Joaquin Valley, CA. Tree: large; vigorous; spreading and dense; flowers showy, self-fertile; chilling requirement $575 \mathrm{~h}$; leaf glands medium-large, reniform.

Majestic Sweet. Yellow-fleshed, sub-acid, clingstone nectarine. Origin: Le Grand, CA, by L.G. Bradford. Parentage unknown; USPP 18,714; 8 Apr. 2008. Fruit: large; globose, uniform; deep red overcolor smoothly blending into a moderate reddish-orange ground color with some light yellow freckling on the sides toward the apex; yellow flesh with slight red streaking near the stone, firm, crisp, juicy; sub-acidic and sweet; ripens 19 Aug.-1 Sept. in San Joaquin Valley, CA. Tree: medium; vigorous; upright and dense; flowers very large, showy, self-fertile; chilling requirement $625 \mathrm{~h}$; leaf glands absent.

Nectarexquise. White-fleshed, melting, clingstone nectarine. Origin: S.A.R.L. Argo Selection Fruits, Elne, France, by A. Maillard and L. Maillard. Unnamed nectarine O.P.; tested as $02.10 .61 \mathrm{NB}-$ ASF 0328; USPP 19,377; 28 Oct. 2008. Fruit: large; round, uniform; bright purple-red blush covers $90-100 \%$ of pink-washed red ground color with some occurrence of cork-lenticels; white flesh with starred red pigmentation near stone, very firm, very dense; semi-sweet; ripens 8-18 Aug. in Elne, France. Tree: large; vigorous; very productive; flowers showy, self-fertile; leaf glands small, reniform.

Nectarjewel. White-fleshed, melting, clingstone nectarine. Origin: S.A.R.L. Argo Selection Fruits, Elne, France, by A. Maillard and L. Maillard. (Julie x Zaitabo) x Maillarmagie; tested as 03.12.74 NBASF 0426; USPP 19,380; 28 Oct. 2008. Fruit: large; round; pinkwashed red ground color covers up to $90 \%$ with bright purple-red overcolor; flesh white with red pigmentation under skin and around stone, firm, melting, juicy; semi-sweet; ripens between 31 July and 8 Aug. in Elne, France. Tree: large; vigorous; semi-spreading; flowers showy, self-fertile; leaf glands reniform.

Nectracrisp. White-fleshed, late-season, clingstone nectarine. Origin: S.A.R.L. Argo Selection Fruits, Elne, France, by A. Maillard and L. Maillard. Maillarflat O.P.; tested as 02.07.13 NB-ASF 0227; USPP 19,384; 28 Oct. 2008. Fruit: medium to large; round; cream under color covers up to $80 \%$ with bright red overcolor; flesh white with slight red around pit, very firm, juicy, melting; very long shelf life; semi-sweet; ripens end of August to beginning September, $4 \mathrm{~d}$ before September Queen in Elne, France. Tree: large; vigorous; semi-spread; flowers showy, self-fertile; leaf glands reniform.

Nectrajune. White-fleshed, melting, semi-clingstone to clingstone nectarine. Origin: S.A.R.L. Argo Selection Fruits, Elne, France, by A. Maillard and L. Maillard; (Julie x Zaitabo) x Maillaferarie; tested as 03.12.03 NB-ASF 0321; USPP 19,379; 28 Oct. 2008. Fruit: large to very large; round, uniform; bright purple covers $90-100 \%$ of pinkwashed red ground color; flesh white with red pigmentation under skin and around stone, firm, melting, juicy; semi-sweet; ripens 19-28 June, 1-2 d before Snowqueen in Elne, France. Tree: large; vigorous; very productive; semi-spreading; flowers showy, self-fertile; leaf glands small, globose.

Pearlicious III. White-fleshed, sub-acid, freestone nectarine. Origin: Le Grand, CA by L.G. Bradford; Rose Diamond x unnamed nectarine; USPP 18,706; 1 Apr. 2008. Fruit: large; globose, uniform; dark red overcolor smoothly blending into a moderate red ground color with yellowish-white freckling toward the apex; flesh white with very slight amount of red streaking very near the apex of the stone, very firm, crisp; sub-acidic and sweet; ripens 14-24 June in San Joaquin Valley, CA. Tree: large; vigorous; upright and dense; flowers large, showy, self-fertile; chilling requirement $600 \mathrm{~h}$; leaf glands medium, globose. 
Pearlicious V. White-fleshed, melting, clingstone nectarine. Origin: Le Grand, CA, by L.G. Bradford. 5P452 x unnamed low-chill nectarine; USPP 19,917; 14 Apr. 2009. Fruit: medium to large; globose; mostly red over-color; flesh white, firm and melting; very high sugar; ripens late June in San Joaquin Valley, CA. Tree: vigorous; hardy; flowers showy; self-fertile; chilling requirement $525 \mathrm{~h}$; leaf glands reniform.

Royal Ruby. Yellow-fleshed, low-chill, very early maturing, clingstone nectarine. Origin: Modesto, CA, by G.N. Zaiger, L.M. Gardner and G.G. Zaiger. Red Roy x 57Z707; USPP 18,734; 15 Apr. 2008. Fruit: large; globose, uniform; red overcolor covering yellow ground color; flesh yellow; firm; ripens 10-16 May in Modesto, CA. Tree: large; vigorous; upright; flowers large, showy; self-fertile; chilling requirement $300 \mathrm{~h}$; leaf glands medium-large, reniform.

Snow Pearl. White-fleshed, sub-acid, clingstone nectarine. Origin: Le Grand, CA, by L.G. Bradford. Ruby Diamond x Regal Pearl; USPP 18,696; 1 Apr. 2008. Fruit: large; globose, uniform; very deep red overcolor mottled over dark pink ground color with slight moderate-orange freckling toward the apex; flesh yellowish-white with moderate red streaking next to the stone, firm, meaty, melting, juicy; sub-acidic and very sweet; ripens 24 Aug.-4 Sept. in San Joaquin Valley, CA. Tree: medium; vigorous; spreading and dense; flowers very large, showy, self-fertile; chilling requirement 625 h; leaf glands medium, globose.

Sugarred I. Yellow-fleshed, clingstone nectarine. Origin: Le Grand, CA, by L.G. Bradford. Spring Bright x unnamed nectarine; USPP 18,693; 1 Apr. 2008. Fruit: large; globose, uniform; dark red overcolor smoothly blending into strong reddish orange ground color with the slightest amount of pale orange-yellow freckling; flesh deep red toward the skin finally bleeding into orange yellow close to the stone, very firm, crisp, juicy; acidic and sweet; ripens 19-29 June in San Joaquin Valley, CA. Tree: medium; moderate vigor; spreading and dense; flowers very large, showy, self-fertile; chilling requirement $525 \mathrm{~h}$; leaf glands small, globose.

Sugarred II. Red-fleshed, melting, clingstone nectarine. Origin: Le Grand, CA, by L.G. Bradford. Spring Bright x unnamed low-chill nectarine; USPP 19,890; 7 Apr. 2009. Fruit: large; globose; mostly red overcolor; flesh mostly red, firm, melting; acidic and sweet; ripens early June in San Joaquin Valley, CA. Tree: medium; vigorous, hardy; flowers showy, self-fertile; chilling requirement $400 \mathrm{~h}$; leaf glands globose.

Sugarred III. Red-fleshed, melting, clingstone nectarine. Origin: Le Grand, CA, by L.G. Bradford. Spring Bright x unnamed nectarine; USPP 19,918; 14 Apr. 2009. Fruit: large, globose; mostly red over-color; flesh full red, firm and melting; acidic and sweet; ripens early July in San Joaquin Valley, CA. Tree: vigorous, hardy; flowers showy, self-fertile; chilling requirement $600 \mathrm{~h}$; leaf glands reniform.

Suhong. Yellow-fleshed, melting, clingstone nectarine. Origin: NHRI, RDA, Suwon, Korea by J.H. Jun et al. SunGlo x Cheonhong; tested as Wonkyo Da-17; selected in 1999, introd. 2003. Fruit: large, $268 \mathrm{~g}$; ovate; purplish red overcolor covering 100\% of yellowishorange ground color; flesh light yellow; sweet; ripens mid-August in Suwon, Korea, $18 \mathrm{~d}$ after Cheonhong. Tree: vigorous; productive; semi-upright; flowers large, showy, self-fertile, pink; leaf glands reniform.

Summer Lion IV. Yellow-fleshed, midseason, freestone nectarine. Origin: Selma, CA by D.M. Serimian and L.M. Serimian. June Lion x Summer Lion II; USPP 18,935; 17 June 2008. Fruit: large; ovate, uniform; bright red overcolor covering apricot-yellow ground color; yellow flesh with red flecking throughout from skin to pit cavity, firm; ripens 15-30 July in San Joaquin Valley, CA. Tree: medium; vigorous; upright and spreading; flowers non-showy, self-fertile; leaf glands reniform.

Summer Prince. White-fleshed, melting, late-season, freestone nectarine suitable for local market. Distinct from yellow-fleshed peach Summerprince introd. by ARS-USDA and described in List 36. Origin: ARC Infruitec-Nietvoorbij, South Africa by J.H. Acker. Parentage unknown; introd. 2008. Fruit: medium; ovate, uniform; red overcolor covering 50-80 \% of white ground color; flesh white, firm, melting; very sweet, low acid; ripens $2^{\text {nd }}$ week of February on Bien Donné, Stellenbosch, South Africa. Tree: medium; moderately vigorous; semi-spreading; productive; flowers showy, self fertile, medium-pink; chilling requirement 600-800 h (Infruitec Units); leaf glands globose.

UFRoyal. Yellow-fleshed, early-season, non-melting, clingstone nectarine. Origin: Univ. of Florida, by J.X. Chapparo; [Fla 86-28c (Fla. 9-20 O.P.) x Tropic Beauty] O.P.; tested as Fla. 97-17cn; selected in 1997; USPP 20,314; 15 Sept. 2009. Fruit: medium-large; oval, uniform; red overcolor covering $90-100 \%$ of bright yellow ground color; flesh yellow and may contain small red flecks, no red color at the pit, firm, juicy; balanced taste; ripens 5-15 May in Gainesville, FL. Tree: medium; moderately vigorous; semi-spreading; flowers showy, pink; chilling requirement $250 \mathrm{~h}$; leaf glands small, reniform.

\section{PASSION FRUIT}

Jorge Ochoa, Horticulture Program, Long Beach City College, Long Beach, CA

Black Beauty. Self-fertile, very productive, purple-fruited passion fruit. Origin: Kartuz Greenhouses, Vista, CA, by P. Worley. Selection of Passiflora edulis; introd. 1983. Fruit: roundish; deep purple-black; flavor good. Vine: compact; vigorous; stem stout and glabrous; leaves leathery, lustrous, three-lobed; flowers fragrant, white and mauve; easy to cultivate; minimum temperature $-4{ }^{\circ} \mathrm{C}$.

Black Knight. Self-fertile, high-yielding, purple-fruited passion fruit. Origin: Pacific Southwest Nursery, San Diego, CA, by P. Worley. Complex hybrid of multiple cultivars of $P$. edulis. Fruit: large; elliptical; very fragrant; deep purple-black; flavor excellent. Vine: slow growing with a compact habit; stem stout and glabrous; leaves leathery, lustrous, three-lobed; flowers white and purple; well suited to container cultivation.

Brazilian Gold. Self-sterile, high-yielding, yellow-fruited passion fruit. Origin: selection of $P$. edulis var. flavicarpa. Fruit: very large; golden; flavor tart even when fully ripe. Vine: vigorous; stem stout and glabrous; leaves shiny, three-lobed; flowers large, white petals and sepals, corona filaments white with a deep purple center.

Edgehill. Self-fertile, purple-fruited passion fruit. Origin: Vista, CA, by P. Thomson. Selection of $P$. edulis. Fruit: large, very fragrant, deep purple-black; flavor excellent. Vine: vigorous; growth habit large; stem stout and glabrous; leaves leathery, three-lobed; flowers white and purple; resembles Black Knight, with larger fruit.

Frederick (Bountiful Beauty). Self-fertile, very productive, redfruited passion fruit. Origin: Pacific Southwest Nursery, San Diego, CA, by P. Worley. Brazilian Gold x Kahuna; introd. 1993. Fruit: red; very large; well flavored. Vine: vigorous; flower large, white and deep indigo; stem stout and glabrous; leaves leathery, threelobed; plants propagated by seed are variable and do not offer the same quality fruit.

Frosty. Medium-size, purple-fruited passion fruit. Origin: California, by R. McCain. Fruit: purple; round; large; flavor good, sweet. 
Vine: vigorous; stem stout and glabrous; leaves leathery, lustrous, three-lobed; flowers large, white and purple; more cold-tolerant than other passion fruit cultivars.

Golden Giant. Very productive, large, yellow-fruited passion fruit. Origin: Australia; selection of $P$. edulis var. flavicarpa. Fruit: huge; oval; yellow; pulp sweet. Vine: vigorous; stem stout, glabrous; leaves leathery, three-lobed; flowers large, white with purple centers.

Kahuna. Self-fertile, very productive, purple-fruited passion fruit. Origin: California, by P. Worley and R. McCain. Fruit: purple; elliptical; flavor very sweet and mild. Vine: vigorous; flowers $8.9 \mathrm{~cm}$ wide, very elegant, with white petals, purple at base.

Nancy Garrison. Purple-fruited passion fruit. Origin: San Jose, CA; selection of $P$. edulis. Fruit: large; purple; pulp light-orange, with crunchy seeds; tart but well flavored. Vine: vigorous; flowers large, white and deep indigo.

Norfolk. Self-sterile, very productive, red-fruited passion fruit. Origin: unknown, selection of $P$. edulis var. flavicarpa. Fruit: large; reddish-purple; high quality; very juicy and sweet. Vine: vigorous; stem stout and glabrous; leaves leathery, lustrous, threelobed; flowers large, pure white.

Possum Purple. Self-fertile, productive, red-fruited passion fruit. Origin: Possum Trot Nursery, Miami, FL, by R. Barnum. Hybrid of P. edulis var. edulis $\mathrm{x}$ P. edulis var. flavicarpa. Fruit: round to ovoid; rind tough, smooth and waxy; pulp highly aromatic, orange-colored, with hard, dark brown or black seeds. Vine: vigorous; leaves shiny, deeply three-lobed; flowers showy, fragrant, 5.1 to $7.6 \mathrm{~cm}$ wide, white with purple centers.

Purple Giant. Self-fertile, purple-fruited passion fruit. Origin: Unknown, selection of $P$. edulis. Fruit: rind hard; flavor pleasant, sweet and slightly acidic. Vine: vigorous; stem glabrous, stout; leaves deeply three-lobed, lustrous above; flowers white with purple bases, corona filaments as long as the petals.

Red Riviera. Productive, red-fruited passion fruit. Origin: Hawaii, by $C$. Riviera. natural hybrid of $P$. edulis var. edulis $\mathrm{x} P$. edulis var. flavicarpa. Fruit: red; very large; well flavored. Vine: vigorous; flowers large; white and deep indigo.

Red Rover. Productive, red-fruited passion fruit. Origin: California, by P. Worley and R. McCain. Brazilian Gold x Kahuna. Fruit: red; large; fragrant; flavor good. Vine: vigorous; flowers, white with deep indigo centers, large petals; very similar to Frederick, with large, red fruit.

\section{PEACH}

Ksenija Gasic, Department of Environmental Horticulture, Clemson University, Clemson, SC

W.R. Okie, USDA-ARS, Southeastern Fruit and Tree Nut Research Laboratory, Byron, GA

Andes Du-1. Yellow-fleshed, clingstone peach. Origin: University of Chile, Andes Nursery Association (Australis Breeding ${ }^{\circledR}$ ), by R. Infante. Parentage unknown; tested as SAG53/08; introd. 2008. Fruit: medium-large; round; uniform; red overcolor covering 50$60 \%$ of yellow-orange ground color; flesh yellow, firm, juicy, nonmelting; sweet; ripens 21 Dec. in Santiago, $20 \mathrm{~d}$ before Carson. Tree: medium-large; moderately vigorous; semi-spreading; flowers non-showy, self-fertile; leaf glands absent.

Arkangel. Orange-fleshed, sub-acid, low browning, clingstone peach resistant to powdery mildew. Origin: Centro de Recursos
Genéticos y Mejoramiento de Prunus, Huimilpan, Queretaro, Mexico, by S. Perez; A298 x 23D; registered at SNICS, 2009; introd. 2002. Fruit: medium; bright-red overcolor covering $20-50 \%$ of golden-yellow ground color; flesh deep orange; firm, non-melting sub-acid, excellent flavor; resistant to oxidative browning; ripens $1^{\text {st }}$ week of June in Huimilpan, Queretaro, central Mexico. Tree: moderately vigorous; spreading; medium to high bud density; productive; resistant to powdery mildew (Sphaerotheca pannosa); flowers non-showy, self-fertile, pink to pale pink; late blooming, chilling requirement 350-500 h; leaf glands medium, reniform.

Armoore. Yellow-orange-fleshed, sub-acid, clingstone peach. Origin: Centro de Recursos Genéticos y Mejoramiento de Prunus, Huimilpan, Queretaro, Mexico, by S. Perez. H2-22 x Vinegold; registered at SNICS, 2009; introd. 2002. Fruit: medium-large; bright red overcolor covering $10-20 \%$ of golden-yellow ground color; flesh yellow-orange, firm, non-melting; good flavor, subacid; resistant to oxidative browning; ripens first week of July, 6 weeks before local, open-pollinated cultivars (criollos) in Huimilpan, Queretaro, central Mexico. Tree: medium; moderately vigorous; upright; medium bud density; productive; resistant to powdery mildew; flowers medium, showy, self-fertile, pale pink; late blooming,chilling requirement $500 \mathrm{~h}$; leaf glands medium, reniform

Autumn Crunch. Yellow-fleshed, late-season, canning clingstone peach. Origin: ARC Infruitec-Nietvoorbij, South Africa, by J.H. Acker. Parentage unknown; introd. May 2008. Fruit: large; round, uniform; bright yellow ground color with no red overcolor; little pubescence; flesh yellow; firm, non-melting; medium sweet, mildly acidic; ripens $4^{\text {th }}$ week February on Bien Donné, Stellenbosch, South Africa. Tree: medium; mildly vigorous; semi-spreading; productive; flowers showy; self-fertile, medium pink; chilling requirement 600 800 h (Infruitec Units); leaf glands reniform.

BRS Âmbar. Yellow-fleshed, non-melting, clingstone canning peach. Origin: EMBRAPA Clima Temperado, Pelotas, Brazil by M. Bassols Raseira and B. Nakasu. Esmeralda x Conserva 555 (Ambrosio Perret x Cerrito). Fruit: large, $>130$ g on average; flesh yellow, non-melting, juicy; balanced acidity and sugar; ripens after 20 Nov. in Pelotas, Brazil. Tree: vigorous; spreading to semispreading; flowers non showy; chilling requirement $300 \mathrm{~h}$.

BRS Kampai. White-fleshed, low-acid, low-chill, semi-clingstone peach. Origin: EMBRAPA Clima Temperado, Pelotas, Brazil, by M. Bassols Raseira and B. Nakasu; Chimarrita x Flordaprince; tested in subtropical areas as Cascata 834; registered at the Ministry of Agriculture in Brazil under the National cultivar No. 25.444; protected as No. 21806.000034.2009. Fruit: roundish; conic; greenish-cream background color covered on $50-80 \%$ with red overcolor; flesh white; semi-free stone; low acid, sweet; ripens in midNovember, a few days before Rubimel and Premier in Pelotas, Brazil. Tree: moderately vigorous; semi-vertical; flowers medium to large, showy, self-fertile, pink; chilling requirement $200 \mathrm{~h}$; leaf glands small, reniform.

BRS Libra. Yellow-fleshed, low chill, early ripening, clingstone canning peach. Origin: EMBRAPA Clima Temperado, Pelotas, Brazil, by M. Bassols Raseira and B. Nakasu. Conserva 594 x Pepita; tested as Conserva 1125. Fruit: medium; round; smooth skin with a light fuzz; golden yellow with no overcolor; flesh yellow, firm, non-melting; pleasant aroma, balanced sweet-acid taste; ripens very early, mid-October, in Pelotas, Brazil, the earliest processing peach in southern Brazil. Tree: vigorous; spreading; flowers medium to large, showy, self-fertile, wide elliptic pink petals; chilling requirement less than $200 \mathrm{~h}$; leaf glands small, reniform.

Cascade. Yellow-fleshed, non-melting, medium-late-season, canning clingstone peach. Origin: ARC Infruitec-Nietvoorbij, South Africa, by J.H. Acker. Parentage unknown; introd. 2007. Fruit: 
large; round; orange-yellow ground color with no red overcolor; little pubescence; flesh orange-yellow, non-melting; medium sweet, mildly acidic; ripens $4^{\text {th }}$ week of January on Bien Donné, Stellenbosch, South Africa. Tree: large; vigorous; upright; productive; flowers non-showy, self-fertile, light to medium-pink; chilling requirement 400-600 h (Infruitec Units); leaf glands globose.

Cederberg. Yellow-fleshed, melting, midseason, freestone peach suitable for drying. Origin: ARC Infruitec-Nietvoorbij, South Africa, by J.H. Acker. Introd. May 2007. Fruit: large; oblate-round; medium-red marbled overcolor covering $35 \%$ of yellow ground color; medium pubescence; flesh yellow; melting; sweet fruit, low acidity; ripens $2^{\text {nd }}$ week of January in on Bien Donné, Stellenbosch, South Africa. Tree: medium; moderately vigorous; semi-upright; productive; flowers showy, self-fertile, medium-pink; chilling requirement 400-600 h (Infruitec Units); leaf glands reniform.

Crispdelice Sun. Yellow-fleshed, clingstone peach. Origin: S.A.R.L. Argo Selection Fruits, Elne, France, by A. Maillard and L. Maillard. Unnamed peach $\mathrm{x}$ unnamed nectarine; tested as 03.05.142 PJ-ASF 0443; USPP 19,231; 16 Sept. 2008. Fruit: very large; round, uniform; red blush covers $80-90 \%$ of surface over yellow-orange ground color; flesh yellow, very firm, dense, juicy; semi-sweet; ripens 1-10 Aug., $6 \mathrm{~d}$ after Elegant Lady in Elne, France. Tree: large; vigorous; semispreading; flowers showy, self-fertile; leaf glands reniform.

Crispregal. Yellow-fleshed, clingstone peach. Origin: S.A.R.L. Argo Selection Fruits, Elne, France by A. Maillard and L. Maillard. Unnamed peach $\mathrm{x}$ unnamed nectarine; tested as 03.05.139 PJ-ASF 0441; USPP 19,178; 2 Sept. 2008. Fruit: very large; round to slightly ovate, uniform; red blush covers $80-90 \%$ of surface over yelloworange ground color; flesh yellow, very firm, dense, juicy; semisweet; ripens 23 July-1 Aug., 3 d before Elegant Lady in Elne, France. Tree: large; vigorous; semi-spreading; flowers showy, selffertile; leaf glands reniform.

Earligold. Yellow-fleshed, firm-melting, early-season, clingstone peach. Distinct from Earligold peach introd. in 1958 by Armstrong Nurseries, Ontario, CA. Origin: ARC Infruitec-Nietvoorbij, South Africa, by J.H. Acker. Parentage unknown; introd. 2009. Fruit: large; round-oblong, uniform; no red overcolor on orange-yellow ground color; little pubescence; flesh yellow, firm, melting; mediumsweet, mildly acidic; ripens $4^{\text {th }}$ week of November in Lethlabile, South Africa. Tree: large; vigorous; semi-spreading; productive; flowers non-showy, self-fertile, medium-pink; chilling requirement 200-400 h (Infruitec Units); leaf glands globose.

Flatprincesse. White-fleshed, semi-clingstone, saucer-shaped peach. Origin: S.A.R.L. Argo Selection Fruits, Elne, France, by L. Maillard and A. Maillard. Maillarflat O.P.; tested as 02.03.21PBPL; registered as 1016569 on 29 Dec. 2004 in France; USPP 20,478; 17 Nov. 2009. Fruit: large, 150-200 g; flat and rounded, uniform; orange-red overcolor covering $80-90 \%$ of yellow-orange ground color; flesh white with slight red pigmentation under the skin and close to the stone, very firm, very dense, juicy; semi-sweet, aromatic; ripens 16-25 Aug., $18 \mathrm{~d}$ after Maillarflat in Elne, France. Tree: medium-large; very vigorous; very productive; semi-upright and dense; flowers large showy, self-fertile, pale-pink; chilling requirement 350-1200 h; leaf glands medium-large, reniform.

GP10. Yellow-fleshed, very late-season, semi-clingstone peach. Origin: Reedley, CA, by M. Gerawan. Prima Gattie O.P.; USPP 18,$191 ; 13$ Nov. 2007. Fruit: large; red overcolor covering $30-80 \%$ of yellow ground color; flesh yellow with red streaks toward pit cavity, very firm, juicy; ripens 16-30 Sept., 7-10 d later than Prima Gattie in San Joaquin Valley, CA. Tree: medium; vigorous; upright and spreading; flowers showy, self-fertile; leaf glands small, reniform.

GP45-11. Yellow-fleshed, freestone peach. Origin: Reedley, CA, by M. Gerawan. O'Henry bud sport; USPP 18,390; 1 Jan. 2008.
Fruit: large; ovate; red overcolor covering yellow ground color; flesh lime-yellow with red; good eating quality; ripens 13-20 July in San Joaquin Valley, CA. Tree: medium; vigorous; upright and spreading; flowers showy, self-fertile; leaf glands reniform.

JR 7827. Yellow-fleshed, freestone, saucer-shaped peach. Origin: Visalia, CA, by I. Martinez. Saucer peach bud sport; USPP 18,832; 27 May 2008. Fruit: small to medium; flat; highly colored; slightly firm to soft, juicy; ripens 15-25 June in San Joaquin Valley, CA. Tree: medium; vigorous; flowers showy, self-fertile; chilling requirement $800 \mathrm{~h}$; leaf glands small, reniform.

Julienice. Yellow-fleshed, clingstone peach. Origin: S.A.R.L. Argo Selection Fruits, Elne, France by L. Maillard and A. Maillard. Maillargood O.P.; tested as 01.24.14PJ; registered in France as 1016563; 29 Dec. 2004. Fruit: large to very large, 260-290 g; rounded and very slightly flat, uniform; red overcolor covering 80 $90 \%$ of orange ground color; flesh yellow with a slight star-shaped red pigmentation around the stone; very firm, very dense, juicy; even ripening; long shelf life; balanced taste, aromatic; ripens between 26 Aug. and 5 Sept., $10 \mathrm{~d}$ after O'Henry (Mercil) in Elne, France. Tree: medium-large; very vigorous; semi-upright to semi-spread; flowers medium-large showy, self-fertile, pink; chilling requirement 350$1200 \mathrm{~h}$; leaf glands medium, reniform.

May Princess. Yellow-fleshed, non-melting, early-ripening, clingstone peach. Origin: Le Grand, CA, by L.G. Bradford. Parentage unknown; USPP 18,771; 29 Apr. 2008. Fruit: medium; oblate, uniform; dark red mottled overcolor covering yellow ground color; flesh yellow with red freckling next to skin with further maturity, firm, juicy, non-melting; acidic and sweet; ripens 19-27 May in San Joaquin Valley, CA. Tree: large; vigorous; spreading and dense; flowers showy, self-fertile; chilling requirement $350 \mathrm{~h}$; leaf glands medium, reniform.

Mihong. White-fleshed, early-season, melting, clingstone peach. Origin: NHRI, RDA, Suwon, Korea, by J.H. Jun et al. Yumyeong x Chiyomaru; tested as Wonkyo Da-18; selected 2000; introd. 2005. Fruit: small, $177 \mathrm{~g}$; oblate; light red overcolor; flesh cream-white, no red in flesh nor around the pit, soft, melting; medium size pits with tendency to split; ripens early July in Suwon, Korea, $10 \mathrm{~d}$ after Baekmijosang. Tree: moderately vigorous; spreading; flowers large, showy, self-fertile, pink; leaf glands reniform.

Moscato Blanco. White, firm, late-season, mid-chill, melting, freestone peach. Origin: Co-property of Ministry of Agriculture \& National Agricultural Research Institute of Uruguay INIA, by R. De Lucca, R. Zeballos, J. Soria, and J. Pisano. Parentage involves Pavia Manteca, Pavia Moscatel, EarliGrande, and Flordaking; introd. 2008; PVR applied for. Fruit: medium-large; round-hearted, some tip; $50 \%$ red blush; flesh white, red fibers close to stone, firm; good aroma, very good flavor; ripens 28 Jan.-3 Feb., 43 d after Flavorcrest. Tree: medium; moderate vigor; open, medium-dense; very productive; flowers non-showy; chilling requirement $600 \mathrm{~h}$; leaf glands round; low susceptibility to bacterial spot (Xanthomonas campestris pv. pruni).

Moscato Delicia. Yellow, very firm, late, mid-chill, freestone, melting peach. Origin: Ministry of Agriculture \& National Agricultural Research Institute of Uruguay INIA, by R. De Lucca, R. Zeballos, J. Soria, and J. Pisano. Parentage involved Pavia Manteca, Pavia Moscatel, EarliGrande, and Flordaking; introd. 2009; PVR applied for. Fruit: large; round, symmetric; 60\% red blush, attractive; flesh yellow with abundant red fibers against the stone, very firm; very good flavor, little aroma; ripens 28 Feb.-7 Mar., 18-25 d after O'Henry. Tree: large; medium vigor; spreading; medium to dense; productive; flowers non-showy; chilling requirement $600 \mathrm{~h}$; leaf glands reniform; medium susceptibility to bacterial spot. 
Moscato Tardio. Yellow, very firm, very late, mid-chill, melting, freestone peach. Origin: Ministry of Agriculture \& National Agricultural Research Institute of Uruguay INIA, by R. De Lucca, R. Zeballos, J. Soria, and J. Pisano; Parentage involved Pavia Manteca, Pavia Moscatel, EarliGrande, and Flordaking. Introd. 2009; PVR applied for. Fruit: large; round, symmetric; 60\% red overcolor, attractive; flesh yellow, abundant red fibers against stone, very firm, crispy, low juiciness; very good flavor, little aroma; little tendency to crack; ripens 9-16 Mar., one week after Moscato Delicia and 27-34 d after O'Henry. Tree: large; medium vigor; spreading; medium dense; productive; flowers non-showy; chilling requirement $600 \mathrm{~h}$; leaf glands reniform; medium susceptibility to bacterial spot.

Neptune I. White-fleshed, sub-acid, freestone peach. Origin: Le Grand, CA, by L.G. Bradford. Red Glen x unnamed peach; USPP 18,816; 13 May 2008. Fruit: medium; oblate, uniform; dark red overcolor over a dark yellowish-pink ground color with very little freckling; flesh greenish-white with deep red flecking and bleeding, especially near the stone; sub-acid; ripens 8-16 July in San Joaquin Valley, CA. Tree: large; vigorous; upright and dense; flowers showy, self-fertile; chilling requirement 575 h; leaf glands small, reniform.

Neptune V. Yellow-fleshed, sub-acid, melting, freestone peach. Origin: Le Grand, CA, by L.G. Bradford. Grand Pearl x Neptune I; USPP 20,117; 23 June 2009. Fruit: medium; very oblate; mostly red overcolor; flesh yellow, firm, melting; sub-acid and sweet; ripens mid-June in San Joaquin Valley, CA. Tree: vigorous; flowers showy, self-fertile; chilling requirement $625 \mathrm{~h}$; leaf glands reniform.

NJ350. Yellow-orange-fleshed, melting, clingstone peach. Origin: Rutgers University, by J.C. Goffreda and A.M. Voordeckers. Garnet Beauty x Sentry; USPP 19,382; 28 Oct. 2008. Fruit: large; round; mottled red over an orange-red blush with orange-red ground color; flesh yellow-orange, firm, melting; semi-acidic; ripens between 27 June and 15 July at Cream Ridge, NJ. Tree: vigorous; spreading; cold tolerant; flowers non-showy, self-fertile; leaf glands reniform.

NJ351. Yellow-fleshed, late-midseason, low-acid, freestone peach. Origin: Rutgers University, by J.C. Goffreda and A.M. Voordeckers. NJ304 x J19-19-862144; USPP 18,224; 20 Nov. 2007. Fruit: large; round; red overcolor covering bright golden-yellow ground color; flesh yellow, firm, nearly non-melting, juicy; sweet, low acid; ripens between 9-25 Aug. at Cream Ridge, NJ. Tree: moderately vigorous; spreading; flowers small, non-showy, self-fertile; leaf glands small, reniform.

NJF15. Yellow-fleshed, non-melting, clingstone, saucer-shaped peach. Origin: Rutgers University, by J.C. Goffreda and A.M. Voordeckers. B7-151-752080 x NJF7; USPP 20,128; 30 June 2009. Fruit: large; flat; mottled red overcolor on a bright yellow-orange ground color; flesh yellow, non-melting; sweet, spicy; ripens 12-30 July at Cream Ridge, NJ. Tree: vigor below average; slightly spreading; flowers showy, self-fertile; leaf glands reniform.

NJF16. Yellow-fleshed, non-melting, clingstone, saucer-shaped peach. Origin: Rutgers University, by J.C. Goffreda and A.M. Voordeckers. A43-143-782081 x NJF4; USPP 18,997; 1 July 2008. Fruit: large; flat; bright golden-yellow ground color and no red overcolor; flesh yellow, firm, juicy non-melting; sweet; ripens 23 July-5 Aug. at Cream Ridge, NJ. Tree: vigorous; moderately spreading; flowers showy, self-fertile; leaf glands small reniform.

NJF17. Yellow-fleshed, non-melting, clingstone, saucer-shaped peach. Origin: Rutgers University, by J.C. Goffreda and A.M. Voordeckers. A43-143-782081 x D33-1-86227; USPP 19,383; 28 Oct. 2008. Fruit: medium; flat; bright green-yellow to yellow ground color with no red overcolor; flesh yellow, firm, non-melting; sweet; tendency to crack; ripens 27 July-14 Aug. at Cream Ridge,
NJ. Tree: vigorous; cold tolerant; flowers non-showy, self-fertile; leaf glands reniform.

NJF18. Yellow-orange-fleshed, melting, semi-clingstone, saucershaped peach. Origin: Rutgers University by J.C. Goffreda and A.M. Voordeckers. H15-20-90258 x A34-160-782118; USPP 19,273; 30 Sept. 2008. Fruit: large; oblate; mottled red over color on an orange ground color; flesh yellow-orange, firm, melting; sweet; ripens 21 July-2 Aug. at Cream Ridge, NJ. Tree: large; vigorous; slight upright; flowers showy, self-fertile; leaf glands medium, reniform.

Pavia Sauce. Yellow, firm, late, mid-chill, melting, clingstone peach. Origin: Co-property of Ministry of Agriculture \& National Agricultural Research Institute of Uruguay INIA, by R. De Lucca, R. Zeballos, J. Soria, and J. Pisano. Clonal selection from the old local cultivar Pavia Manteca; introd. 2004; PVR applied for. Fruit: medium to large; round; $50 \%$ red blush; flesh yellow, firm; very good flavor; ripens 4-14 Feb., 51 d after Flavorcrest. Tree: very large; vigorous; upright to moderate spread; medium dense; productive; flowers non-showy; chilling requirement $600 \mathrm{~h}$; leaf glands round; less susceptible to bacterial spot than Pavia Manteca.

P.F. 8 Ball. Yellow-fleshed, freestone peach. Origin: Coloma, MI, by P. Friday. Parentage unknown. USPP 18,534; 26 Feb. 2008 Fruit: spherical; dark red overcolor covering $90 \%$ of dark yellow ground color; flesh yellow, very firm, resilient texture; ripens 25-29 July in Coloma, MI. Tree: medium; moderately vigorous; spreading; very resistant to bacterial leaf and fruit spot; flowers non-showy, selffertile; leaf glands small, globose.

P.F. Big George. Light yellow-fleshed, very late-season, freestone peach. Origin: Coloma, MI, by P. Friday. Parentage unknown; USPP 19,639; 20 Jan. 2009. Fruit: large; spherical; dark red overcolor covering $10 \%$ of yellow ground color; flesh light yellow with red around the pit; very sweet; resistant to brown rot; ripens very late, $45 \mathrm{~d}$ after Redhaven in southwest Michigan. Tree: medium; vigorous; very resistant to bacterial leaf and fruit spot; flowers showy, self-fertile; leaf glands globose.

P.F. Early 8 Ball. Yellow-fleshed, freestone peach. Origin: Coloma, MI, by P. Friday. Parentage unknown; USPP 19,243; 16 Sept. 2008. Fruit: large; spherical; dark red blush covers $95 \%$ of surface over dark yellow ground color; flesh yellow with mottling of red and red around the pit, very firm; ripens 12-19 July at Coloma, MI. Tree: medium; vigorous; spreading; very resistant to bacterial leaf and fruit spot; flowers non-showy, self-fertile; leaf glands globose.

Pearl Princess V. White-fleshed, melting, freestone peach. Origin: Le Grand, CA, by L.G. Bradford. Grand Pearl x Snow Princess; USPP 19,919; 14 Apr. 2009. Fruit: large; round to elliptical, base rounded; deep red overcolor with pale greenish under color; flesh yellowish-white, acquiring deep pink streaking toward stone at maturity, firm, melting; tasty balance of sugar, excellent eating quality; ripens early June in San Joaquin Valley, CA. Tree: medium; vigorous; flowers showy, self-fertile; chilling requirement $500 \mathrm{~h}$; leaf glands reniform.

Pink Ring. White-fleshed, midseason, semi-clingstone, sub-acid, saucer-shaped peach. Origin: CRA-Unità di Ricerca per la Frutticoltura di Forli, Italy, by A. Liverani and D. Giovannini. (Flavortop x Snow Queen) x Stark Saturn. Protected in Spain, No. 20084838; 29 Oct. 2008. Fruit: medium; flat, medium uniform; red covers 40$50 \%$ of surface over white ground color; flesh medium-firm, melting; sub-acid; ripens 14 July in Forli, 3 d before Redhaven. Tree: medium; spreading; vigorous; dense; very productive; flowers showy; leaf glands reniform. 
Princess Time. Yellow-fleshed, early-season, clingstone peach. Origin: Le Grand, CA, by L.G. Bradford; 1P1152 x unnamed lowchill peach; USPP 19,545; 2 Dec. 2008. Fruit: large; globose; mostly red overcolor; flesh yellow, firm and melting; acidic and sweet; ripens early June in San Joaquin Valley, CA. Tree: medium; vigorous; spreading and dense; flowers showy, self-fertile; chilling requirement $500 \mathrm{~h}$; leaf glands globose.

Rose Princess. Yellow-fleshed, non-melting, early-season, clingstone peach. Distinct from Roseprincess nectarine introd. in 1989 by USDA-ARS. Origin: Le Grand, CA, by L.G. Bradford. 5P57 O.P.; USPP 18,791; 6 May 2008. Fruit: large; globose to oblate, uniform; dark red mottled over a moderate reddish-orange background with slight yellowish-white freckling on the sides; flesh brilliant yellow acquiring strong red freckling with increasing maturity, firm, juicy, non-melting; acidic and sweet; ripens 29 May-8 June in San Joaquin Valley, CA. Tree: medium; vigorous; spreading and open; flowers showy, self-fertile; chilling requirement $525 \mathrm{~h}$; leaf glands large, reniform.

Scarlet. Yellow-fleshed, melting, early-season, clingstone dessert peach suitable for export with delayed storage. Origin: ARC Infruitec-Nietvoorbij, South Africa, by J.H. Acker. Parentage unknown; introd. 2009. Fruit: large; round, uniform; medium red overcolor covering $90-95 \%$ of orange-yellow ground color; little pubescence; flesh yellow, melting; medium sweet, mildly acidic; ripens $3^{\text {rd }}$ week of November on Bien Donné, Stellenbosch, South Africa. Tree: large; strong vigor; semi-spreading; productive; flowers showy, self-fertile, medium-pink; chilling requirement 200-400 h (Infruitec Units); leaf glands globose.

Snow Angel. White-fleshed, firm, very early-season, clingstone peach. Origin: Modesto, CA, by G.N. Zaiger, L.M. Gardner, and G.G. Zaiger. 174LE309 x 2LD470; USPP 18,750; 22 Apr. 2008. Fruit: medium; globose; red overcolor covering yellow ground color; flesh white to pale yellow, firm; good eating quality; ripens 916 May in Modesto, CA. Tree: large; vigorous; upright semispreading; flowers large, showy, self-fertile; chilling requirement $200 \mathrm{~h}$; leaf glands small, globose.

Soomee. White-fleshed, late-season, melting, clingstone peach. Origin: NHRI, RDA, Suwon, Korea, by J.H. Jun et al. Yumyeong x Chiyomaru; tested as Wonkyo Da-22; selected 2001; introd. 2004. Fruit: large, 306 g; oblate; light red overcolor; flesh creamy-white, with strong red pigmentation around the pit, soft, melting; sweet; ripens very late August in Suwon, Korea, $12 \mathrm{~d}$ after Yumyeong. Tree: moderate vigor; productive; semi-upright; flowers large showy, self-fertile, pink; leaf glands small reniform.

Sugarpeach III. Yellow-fleshed, melting, sub-acid, clingstone peach. Origin: Le Grand, CA, by L.G. Bradford; Parentage unknown; USPP 18,753; 22 Apr. 2008. Fruit: large; globose to oblate, uniform; dark red overcolor covering light red ground color with very slight yellowish-white freckling; yellow flesh with strong red streaking next to the skin, firm, melting; sub acid and sweet; ripens 717 June in San Joaquin Valley, CA. Tree: large; vigorous; spreading and dense; flowers showy, self-fertile; chilling requirement $800 \mathrm{~h}$; leaf glands medium, reniform.

Summergold. Yellow-fleshed, non-melting, early-season, clingstone peach suitable for canning. Distinct from Summergold peach introd. in 1970 by USDA-ARS, Byron, GA. Origin: ARC InfruitecNietvoorbij, South Africa, by J.H. Acker. Parentage unknown; introd. 2009. Fruit: large; round, uniform; no red overcolor; little pubescence; flesh orange-yellow, non-melting; medium sweet, mildly acidic; ripens $2^{\text {nd }}$ week of Dec. on Bien Donné, Stellenbosch, South Africa. Tree: moderate vigor; semi-spreading; productive; flowers showy, self-fertile, light-pink; chilling requirement 400-600 $\mathrm{h}$ (Infruitec Units); leaf glands reniform.
Summertime. Yellow-fleshed, melting, midseason, clingstone dessert peach suitable for export. Distinct from Summertime peach introd. in 1959 by Stribling's Nursery, Merced, CA. Origin: ARC Infruitec-Nietvoorbij, South Africa, by J.H. Acker. Parentage unknown; introd. 2009. Fruit: large; round, uniform; light red overcolor covering $80-90 \%$ of greenish-yellow ground color; little pubescence; flesh yellow, melting; low sweetness, low acid; ripens $2^{\text {nd }}$ week of December on Bien Donné, Stellenbosch, South Africa. Tree: moderate vigor; semi-spreading; productive; flowers showy, self-fertile, medium-pink; chilling requirement 400-600 h (Infruitec Units); leaf glands reniform.

Sundry. Yellow-fleshed, melting, late-season, freestone peach suitable for drying. Origin: ARC Infruitec-Nietvoorbij, South Africa, by J.H. Acker. Parentage unknown; introd. 2009. Fruit: medium-large; round, uniform; no red overcolor on orange-yellow ground color; little pubescence; flesh orange-yellow, melting; medium sweet, mildly acidic; ripens $4^{\text {th }}$ week of January on Bien Donné, Stellenbosch, South Africa. Tree: moderate vigor; semi-spreading; productive; flowers showy, self-fertile, medium-pink; chilling requirement 400-600 h (Infruitec Units); leaf glands reniform.

Supechsixteen. Yellow-fleshed, non-melting, very early-season, clingstone peach. Origin: Sun World International, Bakersfield, CA, by T.A. Bacon. 94003-024-230 O.P.; tested as PE216; USPP 20,182; 21 July 2009. Fruit: large; round, base round, apex flat, slightly depressed at point; red overcolor with a bright yellow ground color; flesh yellow, slight green near the stone; sweet and moderately acidic; ripens 8 May near Wasco, Kern County, CA. Tree: vigorous; flowers non-showy, self-fertile; chilling requirement $200 \mathrm{~h}$; leaf glands globose.

Sweet Juana. Yellow-fleshed, sub-acid, clingstone peach. Origin: Modesto, CA, by G.N. Zaiger, L.M. Gardner, and G.G. Zaiger. 378LN103 O.P; USPP 19,594; 20 Dec. 2008. Fruit: large; globose, base round to flat; attractive red overcolor; flesh yellow; holds firm on the tree 7-8 d after maturity; sub-acid; ripens 2 weeks after O'Henry in Modesto, CA. Tree: vigorous; upright; flowers showy, self-fertile; chilling requirement $900 \mathrm{~h}$; leaf glands reniform.

Sweet Ring. Yellow-fleshed, early-season, semi-clingstone, subacid, saucer-shaped peach. Origin: CRA-Unità di Ricerca per la Frutticoltura di Forli, Italy, by A. Liverani and D. Giovannini. Spring Lady x Stark Saturn; Protected in Spain, No. 20084837; 29 Oct. 2008. Fruit: medium-small; saucer-shaped, medium uniform; red overcolor covers $60-70 \%$ of yellow ground color; flesh yellow, medium-firm, juicy, melting; sub-acid; ripens 19 June in Forli, $26 \mathrm{~d}$ before Redhaven. Tree: medium; vigorous; semi-upright; productive; flowers showy; leaf glands globose.

UFSharp. Yellow-fleshed, non-melting, clingstone peach. Origin: University of Florida, by J.X. Chaparro and W.B. Sherman. FL9050cn x FL88-6; tested as F1 97-52c; selected 1997. USPP applied for. Fruit: large, $160 \mathrm{~g}$; nearly round with a slight tip; red overcolor covers $60 \%$ of deep yellow-orange ground color; flesh yellow, no red in the flesh at the pit, firm; balanced taste; ripens late May in Gainesville, 5-7 d after UF2000. Tree: vigorous; semi-spreading; flowers showy, self-fertile, pink; chilling requirement $325 \mathrm{~h}$; leaf glands globose; bacterial spot tolerant.

Vinegold. Yellow-fleshed, non-melting, clingstone processing peach. Origin: HRIO, Vineland Station, Canada by N. Miles, K. Slingerland and S. Leuty. NJC 95 x Veecling; tested as V-7828160; introd. 1994. Fruit: large; round - blocky; 30\% red blush over a dark yellow ground color; flesh dark yellow free of red pigments, firm, non-melting; clingstone; good quality; ripens 12 Aug., $6 \mathrm{~d}$ before Veecling. Tree: vigorous; spreading; productive; moderately resistant to bacterial spot, brown rot (Monilinia sp.), and Cytospora canker (Leucostoma persoonii). 
Virgil. Yellow-fleshed, non-melting, clingstone processing peach. Origin: HRIO, Vineland Station, Canada by N. Miles, S. Leuty, S. Wang and R. Guarnaccia. Veecling x NJC 95; tested as V-790638; introd. 1997. Fruit: medium-large; round to slightly oblate; uniform; dark red overcolor covering $50 \%$ of golden yellow ground color; flesh golden yellow, no red around pit; desirable sugar/acid ratio for processing; ripens $15 \mathrm{Aug}$. at Vineland station, $3 \mathrm{~d}$ before Veecling. Tree: moderate vigor; strong and spreading; precocious and productive; moderately resistant to Cytospora canker, bacterial spot and brown rot.

Vulcan. Yellow-fleshed, non-melting, clingstone, processing peach. Origin: HRIO, Vineland Station, Canada, by N. Miles, K. Slingerland and S. Leuty. Veecling x NJC 95; tested as V-790632; introd. 1994. Fruit: medium; round-blocky; $80 \%$ dark red blush over a yellow-orange ground color; yellow-orange flesh free of red pigments; firm; good processing quality; ripens 6 Aug. at Vineland, $12 \mathrm{~d}$ before Veecling. Tree: moderately vigorous; winter hardy; strong scaffold branches; productive; flower light pink, large, showy, self-fertile; chilling requirement $960 \mathrm{~h}$; resistant to bacterial spot, brown rot, and Cytospora canker.

Western Princess. Yellow-fleshed, melting, freestone peach. Origin: Le Grand, CA, by L.G. Bradford. Diamond Princess x unnamed peach; USPP 18,755; 22 Apr. 2008. Fruit: large; globose, uniform; dark red over moderate reddish orange ground color; flesh yellow with red streaking, firm, melting; mildly acidic and sweet; ripens 113 July in San Joaquin Valley, CA. Tree: medium; vigorous; spreading and dense; flowers showy, self-fertile; chilling requirement $500 \mathrm{~h}$; leaf glands medium, reniform.

White Cloud. White-fleshed, clingstone, non-melting peach. Origin: University of Arkansas, by J.R. Clark and J.N. Moore. Allgold x Ark 374; tested as Ark 499; introd. 2009. Fruit: large, 205 g; ripens early midseason, 7 July at Clarksville, AR; firm flesh similar to processing clingstone peaches; $73 \%$ red blush; standard acid, distinct white peach flavor, SS $11.6 \%$; Tree: non-showy, self-fertile flowers; full bloom 20 Mar. in Clarksville, AR; chilling requirement probably near $800 \mathrm{~h}$; highly resistant to bacterial spot.

White Diamond. White-fleshed, freestone peach, with very firm flesh. Origin: University of Arkansas, by J.R. Clark and J.N. Moore. Ark. 392 x White River; tested as Ark 700. USPP applied for. Fruit: large, $206 \mathrm{~g}$; ripens late-season, $10 \mathrm{~d}$ after White River; very firm flesh that softens when fully ripe; $87 \%$ red blush; low acid, light white peach type flavor, very sweet, SS $14.5 \%$. Tree: showy, selffertile flowers; full bloom, 22 Mar. in Clarksville, AR; chilling requirement near $800 \mathrm{~h}$; highly resistant to bacterial spot.

\section{PEACH ROOTSTOCK}

\section{Thomas G. Beckman, USDA-ARS Southeastern Fruit and Tree} Nut Research Laboratory, Byron, GA

Greenpac. A clonal, complex hybrid rootstock for peach. Origin: Agromillora Catalana, Barcelona, Spain, by J. Pinochet. Felinem (almond $\mathrm{x}$ peach) x Cadaman $^{\circledR}$ (peach $\mathrm{x}$ davidiana); tested as PAC 9904-01; introd. 2009. Plant: propagated via hardwood cuttings with difficulty but propagates easily via in vitro methods; unbudded tree is vigorous with green leaves; appears to be sterile; chilling requirement 400-600 h. Rootstock performance: good compatibility with wide range of peach and nectarine cultivars, grafted trees are vigorous, comparable to those on GF677; fruit production is superior to that of GF677; adapted to calcareous soils, resistant to limeinduced chlorosis; resistant to Meloidogyne incognita rootknot nematode and moderately resistant to $M$. javanica; not tolerant to waterlogging, susceptible to crown gall (Agrobacterium tumefaciens) and likely susceptible to lesion nematodes (Pratylenchus vulnus).

\section{PECAN}

\section{L.J. Grauke and T.E. Thompson, USDA-ARS Southern Plains Agricultural Research Center, College Station, TX}

Apalachee. Pecan with high nut quality, excellent scab disease resistance, and high yield potential. Origin: USDA-ARS Pecan Breeding Program, College Station, TX, by L.D. Romberg, T.E. Thompson, and L.J. Grauke. Moore x Schley; crossed in Brownwood, TX in 1948; selected 1960; tested as 1948-13-311; introd. 2009. Nut: oblong with acute apex, rounded base, round in crosssection; 185 nuts $/ \mathrm{kg} ; 54 \%$ kernel; mature early to midseason, similar to Caddo and Barton, about 3 weeks after Pawnee. Kernel: cream to golden; medium, non-trapping dorsal grooves and narrow dorsal ridge; shelling to produce a large proportion of halves and large pieces. Tree: vigorous; central leader growth habit; strong limb angles similar to the Moore parent; protandrous, with early to midseason pollen shed and midseason to late receptivity similar to Desirable; ripens early season, about one week after Pawnee; performed well in Alabama, Georgia, and Texas; resistant to pecan scab (Fusicladium effusum); medium susceptibility to yellow aphid complex (Monelliopsis pecanis and Monellia caryella) and black aphids (Melanocallis caryaefoliae); yields averaged $1793 \mathrm{~kg} / \mathrm{Ha}$. in commercial test near Albany, GA, with excellent prices.

Byrd. Pecan with high nut quality, moderate susceptibility to pecan scab, early nut maturity, and high yield potential. Origin: University of Georgia, by D. Sparks. Wichita x Pawnee; crossed in Watkinsville, GA 1989; selected 2001; tested as No. 89; introd. 2008. USPP 20,867; 23 Mar. 2010. Nut: oblong with cuspidate to cuspidate asymmetric grooved apex, mainly cuspidate base, round in crosssection; non-elevated suture; rough topography on non-suture side; subtle ridges; 104 nuts $/ \mathrm{kg}, 62 \%$ kernel. Kernel: color similar to Desirable; packing tissue is not a problem; excellent shelling to produce $\sim 95 \%$ of intact halves. Tree: leaf architecture similar to Pawnee; vigorous upright tree more suited to close spacing than most cultivars, limb breakage not a problem with high production; protandrous, with effective pollination (in Georgia) by Elliott, Schley, and Stuart with Byrd pollinating Elliott and Schley; stigmatic surface is ox-blood red; nut maturity is early and 0 to 4 days after Pawnee; precocity is very high, $3.5 \mathrm{~kg} /$ tree the 5 th year from planting compared with $0.3 \mathrm{~kg} /$ tree for Desirable; moderately susceptible to pecan scab; black pecan aphid and yellow pecan aphid problems have not been encountered.

INTA Delta I. Vigorous, densely limbed pecan cultivar with large, attractive nuts. Origin: Instituto Nacional de Tecnología Agropecuaria (INTA) Delta del Paraná, Campana, Argentina, by M. Bakarcic, and E. Frusso; seedling on property of the INTA Delta del Paraná; selected by M. Bakarcic 1987; first propagated 1989; introd. 2009. Nut: oblong with acute apex, obtuse base, round in crosssection; 143 nuts/kg; 49\% kernel. Kernel: medium to dark; shelling freely to produce a large proportion of halves and large pieces. Tree: medium to strong vigor; dense crown; flowers with bright red stigmas, large catkins.

INTA Delta II. Pecan with reduced vegetative vigor and sparse to medium branching, for use as dwarf rootstock. Origin: Instituto Nacional de Tecnología Agropecuaria (INTA) Delta del Paraná, Campana, Argentina, by M. Bakarcic and E. Frusso. Seedling located at Campana, Province of Buenos Aires, Argentina; selected by M. Bakarcic 1956; first propagated 1957; introd. 2009. Nut: oval elliptic with obtuse apex, rounded base, round in cross-section; 187 nuts $/ \mathrm{kg}$; 59\% kernel; Kernel: dark; shelling freely to produce a large proportion of halves and large pieces. Tree: weak vigor; sparse to medium branching may allow this tree to be used as a dwarfing rootstock; flowers protogynous, short catkins.

Mandan. Early maturing pecan with excellent yield potential, high nut quality, and good scab resistance. Origin: USDA-ARS Pecan 
Breeding Program, College Station, TX, by T.E. Thompson and L.J. Grauke. BW-1 x Osage; crossed in Brownwood, TX 1985; selected 1996; tested as 1985-1-2; introd. 2009. Nut: oblong elliptic with obtuse apex, rounded base, flattened in cross-section; 116 nuts $/ \mathrm{kg}$; $62 \%$ kernel; mature very early, $4 \mathrm{~d}$ before Pawnee. Kernel: cream to golden; medium, non-trapping dorsal grooves and rounded dorsal ridge; shells easily into full halves; very attractive. Tree: strong branch angles; initiates growth late, after Pawnee; protandrous, with early to midseason pollen shed and mid- to late-season pistil receptivity, similar to Pawnee; good pollenizer for, and pollenized by, Kanza, Wichita and Lakota; resistant to pecan scab; medium susceptibility to yellow aphid complex and black aphids; yields at Brownwood, TX comparable to Pawnee, exceeded Desirable, and with less alternate bearing than both.

\section{PERSIAN WALNUT}

Charles A. Leslie, Walnut Improvement Program, University of California, Davis, CA

Robert Livermore. A lateral-bearing walnut with red seedcoat. Origin: University of California, Davis by G. McGranahan, C. Leslie, and H. Phillips. UC86-11 x Howard; crossed 1991; selected 1998; tested as UC91-75-15. USPP 12,264; 11 Dec. 2001. Nut: 14.1 g; well-filled; $50 \%$ kernel by weight; shell and seal strong; kernels plump, easily removed as halves; pellicles uniformly bright red. Tree: bears terminally and laterally; precocious; protandrous; yield moderate; ripens mid- to late-season 7-10 d before Chandler.

\section{PERSIAN WALNUT ROOTSTOCK}

Charles A. Leslie, Walnut Improvement Program, University of California, Davis, CA

RX1. A phytophthora resistant hybrid clonal rootstock for Persian walnut. Origin: University of California, Davis and USDA-ARS, by G. McGranahan, C. Leslie, W. Hackett, and G. Browne. Juglans microcarpa DJUG 29.11 x J. regia O.P.; crossed 1997; selected 2001; introd. 2009; USPP applied for. Plant: less vigorous than typically used $J$. hindsii x $J$. regia seedling hybrids; light green foliage; easily propagated by tissue culture. Rootstock performance: shows resistance to Phytophthora citricola and P. cinnamomi in greenhouse and field trials; performs well in replant situations and waterlogged conditions.

VX211. A vigorous, nematode-tolerant hybrid clonal rootstock for Persian walnut. Origin: Davis, CA, University of California, Davis and USDA-ARS, by G. McGranahan, C. Leslie, W. Hackett, G. Browne, J. McKenna, T. Buzo, S. Kaku, and M. McKenry. J. hindsii PDS96-43 x J. regia O.P.; crossed 1997; selected 1999; introd. 2009; USPP applied for. Plant: notably more vigorous than typically used $J$. hindsii $\mathrm{x} J$. regia seedling hybrids; readily propagated by tissue culture. Rootstock performance: very vigorous growth habit; grows well in the presence of nematodes (Pratylenchus vulnus and Meloidogyne sp.); moderate resistance to P. citricola.

\section{PINEAPPLE}

Duane P. Bartholomew, Department of Tropical Plant and Soil Sciences, University of Hawaii at Manoa, Honolulu, HI

Geo Coppens d'Eeckenbrugge, CIRAD - UMR CEFE, Montpellier, France

Ching-Cheng Chen, Department of Horticulture, National Chung Hsing University, Taichung, Taiwan

Ajubá. The third hybrid pineapple introd. from the Brazilian hybridization program. Origin: EMBRAPA Cassava \& Tropical Fruits, Cruz das Almas, Brazil, by J.R.S. Cabral. Perolera x Smooth Cayenne; crossed 1985; introd. 2009. Fruit: shell bright yellow; cylindrical; small to medium, $1.6 \mathrm{~kg}$ with crown; flesh yellow; SS $14.5 \%$; titratable acidity $0.6 \%$. Plant: vigorous; leaves smooth; produces 1 sucker and 4 slips at harvest.

Aus-Carnival. Fresh fruit pineapple with very high sugars and high ratoon yields. Origin: Queensland Department of Primary Industries, Maroochy Research Station, Nambour, Australia, by G. Sanewski. CO-2 (73-50) x 53-116; crossed 1993; selected 1997; tested as 7-1627; Australia Plant Breeders Rights Certificate 3631; 21 Oct. 2008. Fruit: green-yellow; ovoid; $1.45 \mathrm{~kg}$; crown large, 301 g; SS 19.2\%; acidity medium; flavor good; flesh yellow, slightly translucent; ratoon yield high. Plant: $53.6 \mathrm{~cm}$ to apex of flowering syncarp; semi-erect; 40.8 leaves, $127.5 \mathrm{~cm}$, and longer than parents; anthocyanins present, mainly on margins and towards the base; piping leaf margin; peduncle medium to long; anthocyanin on peduncle bract medium; slips few, 0.4; suckers on peduncle, 1.2.

Aus-Jubilee. Fresh-fruit pineapple with excellent appearance, sweet, moderate acidity, good flavor, and uniform maturity. Origin: Queensland Department of Primary Industries, Maroochy Research Station, Nambour, Australia, by G. Sanewski. Smooth Cayenne x CO-2 (73-50); crossed 1993; selected 1997; tested as 10-2594; Australia Plant Breeders Rights Certificate 3633; 9 Feb. 2006. Fruit: golden yellow; ovoid; medium, $1.6 \mathrm{~kg}$ with crown; smaller crown and fruitlets than CO-2; flowers and ripens acropetally with strong maturity gradient; flesh firm, fibrous, pale yellow, with good flavor; SS $16 \%$; acidity moderate; ascorbic acid $\geq 25 \mathrm{mg} / 100 \mathrm{cc}$ juice. Plant: vigorous and rapid growth; $56.5 \mathrm{~cm}$ to apex of flowering syncarp; inflorescence bract color at emergence (red bud stage) slightly colored but less than parents; peduncle 24.2 × $2.7 \mathrm{~cm}$; leaves dark green with piping margin, spineless at tips, short to medium; anthocyanin pigment lacking; relative to 73-50, has fewer slips and improved resistance to natural floral induction; relatively few suckers.

Del Monte Gold ${ }^{\mathrm{TM}}$. See MD-2.

Española Roja (Red Spanish, Black Spanish, Key Largo, Havannah, Habana, Cubana, Cowboy, Bull Head, Cumanesa, Native Philippine Red). A traditional cultivar widely grown in Venezuela and the Caribbean basin. Origin: pre-Columbian. Fruit: shell orange; medium, 1.2-2.0 kg with crown, depending on plant size at forced floral induction; barrel-shaped; SS 12\%; acidity low; flesh firm, pale, aromatic, resistant to internal browning. Plant: vigorous; medium; leaves spiny to half-spiny, dark green, though smooth clones have been selected; floral bracts intense bright red; slips 1-3; few - many suckers; tolerant to heat, drought, butt rot, wilt, and phytophthora rots (Phytophthora cinnamomi, P. parasitica); develops chlorosis in high manganese soils; susceptible to nematodes; highly susceptible to Strymon basilides larvae.

FLHORAN41. A bright red, fresh-fruit cultivar, reflecting its Manzana heritage, a great success in the French West Indies, and developing well in La Réunion. Origin: CIRAD-FLHOR, Martinique. Smooth Cayenne x Manzana; crossed by C. Loison 1986; selected by G. Coppens d'Eeckenbrugge and Y. Atsé, 1991; tested as 282 or Scarlett; EU PVR 12,638; 2004. Fruit: orange to bright red where nights are cool or sun radiant; medium, 1.4-2.0 kg with small, erect crown, depending on plant size at forced floral induction; cylindrical; fruitlets medium to large and flat; flesh firm, golden yellow, relatively low fiber; SS $15-18 \%$; acidity similar to Smooth Cayenne but ascorbic acid content higher; core thin. Plant: compact with erect, smooth "piping" leaves; responds well to floral induction; peduncle $19-25 \mathrm{~cm}$, very resistant to lodging; forcing to ripening $14 \mathrm{~d}$ before Smooth Cayenne; few suckers at harvest, but 1-2 slips; resistant to Brazilian fusariosis (Fusarium subglutinans f.sp. ananas); more susceptible than Smooth Cayenne to reniform nematodes (Rotylenchulus reniformis); susceptible to fruitlet core rot.

Honey Gold. A highly aromatic pineapple cultivar with exceptional shelf life. Origin: Del Monte Fresh Produce, Inc., Coral Gables, FL, 
by J.L. Morales, H. Sauter, and T.R. Young. Nineteen crowns of Tainung 11 were planted in Costa Rica and clonal selections made in this group and for three subsequent generations beginning in 1997; introd. 2006. USPP 16,328; 14 Mar. 2006. Fruit: green or reddish when immature, typically yellow like Tainung 11 if picked ripe; medium, $\sim 1.0 \mathrm{~kg}$, range from $0.4-1.7 \mathrm{~kg}$, depends on plant size at forced floral induction; cylindrical to slightly conical; 80-144 fruitlets; short, erect crown; flesh light yellow with intense aroma; titratable acidity $0.93 \%$, seasonal range $0.67-1.33 \%$, higher than Smooth Cayenne; SS 16.2\%; ascorbic acid $15-37 \mathrm{mg} / 100 \mathrm{cc}$, less than $\mathrm{CO}-2$ in the same environment; stores well and has exceptional shelf life at room temperature. Plant: relatively slow growing; medium, to $57 \mathrm{~cm}$ erect; leaves yellowish-green, olive-green and reddish-green, $85 \mathrm{~cm}$ long and $6.0 \mathrm{~cm}$ wide at forced floral induction; few deltoidcuspidate hooked spines at leaf tips; peduncle $\sim 21 \mathrm{~cm}$ long; slips $0-3$.

Imperial. The first fusariosis-resistant cultivar introd. by the Brazilian breeding program, successful when tested on the French market. Origin: EMBRAPA Cassava \& Tropical Fruits, Cruz das Almas, Brazil, by J.R.S. Cabral. Perolera x Smooth Cayenne; crossed 1988; tested as PExSC-56; introd. in 2003. Fruit: uniformly yellow or orange, coloration initiating soon after anthesis and fully completed at harvest; small to medium, $0.60-1.70 \mathrm{~kg}$ without crown, depends on plant size at forced floral induction; cylindrical; fruitlets slightly prominent; crown $120 \mathrm{~g}$; flesh firm, yellow, of excellent flavor; SS 14.5-18.3\%; titratable acidity $0.29-0.70 \% ; 29 \mathrm{mg} / 100 \mathrm{~g}$ ascorbic acid; resistant to transport damage and internal browning. Plant: slow grower; height $49.1 \mathrm{~cm}$ from soil to fruit base; growth habit compact; leaves short to medium, 'D' leaf to $68 \mathrm{~cm}$, dark green on margins and violet (anthocyanins) in centers; smooth ("piping"); peduncle relatively thin, $20 \mathrm{~cm}$ long $\mathrm{x} 3 \mathrm{~cm}$ wide; resistant to fusariosis. Generally 3-5 slips at fruit base; 1 sucker at harvest; disease resistance allows for organic production.

Josapine. A very early fruiting cultivar and the principal fresh-fruit pineapple in Malaysia. Origin: Malaysian Agricultural Research and Development Institute (MARDI), by Y.K. Chan and H.K. Lee. Johor (Nanas Johor) x Smooth Cayenne; introd. 1996. Fruit: dark purple skin ripens to orange-red; relatively small, 1.1 to $1.3 \mathrm{~kg}$; cylindrical; length to $15 \mathrm{~cm}$, diameter to $11.6 \mathrm{~cm}$, core to $2.5 \mathrm{~cm}$; fruitlets medium and slightly bulging; crown medium, occasionally with multiple proliferations; flesh deep golden yellow, slightly fibrous, fairly dry; aroma strong; SS $17 \%$ on peat soil to $22 \%$ on mineral soils; titratable acidity $0.7-0.9 \%$; storage life good; resistant to internal browning. Plant: vigorous; plant height $81 \mathrm{~cm}$; leaves lightly purple-tinged, margins usually spineless with spines at leaftip; leaf width $4.4 \mathrm{~cm}$; leaf number at floral induction 52; fruit/plant weight ratio 0.38 ; plants can be forced $8 \mathrm{mo}$. from planting (on peat); $30 \mathrm{~d}$ from forcing to red-heart, another $85 \mathrm{~d}$ to harvest, $15 \mathrm{~d}$ earlier than Smooth Cayenne; 2-3 shoots; susceptible to bacterial heart rot (Erwinia chrysanthemi) on mineral soils, less so on peat.

Manzana (Bumanguesa). Grown in the same zone as Perolera, and in the western Colombian Andes (Valle del Cauca), under better technical conditions. Origin: possibly a sport from Perolera, the main difference being more regular fruit shape and color. Fruit: medium, smaller than Perolera; uniformly dark to bright red in tropical highlands; globular to shouldered-cylindrical; large, flat fruitlets; flesh pale yellow, firm, retains its juice, allowing street sale of slices; SS $12 \%$; very slightly acidic; no or very little maturity/ sweetness gradient; multiple crowns and basal slips common. Plant: similar adaptation to highland conditions, similar lodging in hot lowlands, as Perolera; susceptible to the nematode Pratylenchus neglectus; tolerant to root knot nematode; resistant to fusariosis.

MD-2 (Del Monte Gold ${ }^{\mathrm{TM}}$ ). A highly productive pineapple with a distinctive flavor, with coconut overtones; dominant pineapple fresh-fruit cultivar worldwide. Origin: Pineapple Research Institute of Hawaii, Mililani, HI, by D.D.F. Williams. 58-1184 x 59-443; crossed 1970; selected 1973; tested as 73-114; introd. c. 1980; named
MD-2 in 1981; introd. 1996. Fruit: intense orange-yellow color; medium large, to $2.5 \mathrm{~kg}$ with crown, depending on plant size at forced floral induction; cylindrical, square-shouldered; fruitlets large, flat, glossy; overly large crown in some environments; flesh clear, sweet, compact, yellow, fibrous but not objectionably so; SS $15-17 \%$; titratable acidity $0.5-1.0 \%$, higher in cool seasons or environments; ascorbic acid 50-90 mg/100 cc juice, four-fold higher than Smooth Cayenne; flavor well developed, with coconut overtones in subtropical environments, less flavorful in the tropics; core more tender, edible, and thinner than Smooth Cayenne; prone to translucence in some environments; exceptionally resistant to internal browning, withstands refrigeration better than CO-2 and other traditional fresh cultivars; forcing to ripening $7 \mathrm{~d}$ before Smooth Cayenne; not suitable for canning. Plant: vigorous; robust; leaves $100 \times 6.5 \mathrm{~cm}$ in large plants; spines small, mainly at leaf tips, comparable to Smooth Cayenne; leaves lack anthocyanin pigmentation; inflorescence bract color at emergence (red bud stage) green, unlike Smooth Cayenne; peduncle relatively short, $15 \mathrm{~cm}$; very susceptible to natural floral induction; more productive, but more susceptible to phytophthora rots and bacterial heart rot, than Smooth Cayenne; tolerant of nematodes but somewhat more susceptible to reniform nematode than Smooth Cayenne; susceptible to fruitlet core rot and fusariosis.

Pérola (Pernambuco, Branco de Pernambuco, Jupi, Abakka, Eleuthera). One of the two most widely grown fresh-market pineapples in Brazil. Origin: ancient cultivar of obscure origin. Fruit: green with a little yellow in the center of mature fruitlets; 0.9$1.6 \mathrm{~kg}$; ovoid when small to markedly conical when large; flesh soft, white and juicy, with exquisite aroma; SS 13-16\%; 30-34 mg/100 $\mathrm{mL}$ ascorbic acid in juice; flowers and ripens acropetally with strong maturity gradient; small, erect (flame-like) crown. Plant: vigorous; medium; leaves dark green, erect and spiny; erect basal slips surround the fruit in some strains; tolerant to drought; resistant to phytophthora rots, mealybug wilt, and nematodes; highly susceptible to fusariosis.

Perolera (Lebrija, Motilona, Capachera, Tachirense). An important fusariosis-resistant pineapple of the northeastern Andes, of Colombia and Venezuela. Origin: pre-Columbian. Fruit: heterogeneous, yellow to orange; large, $1.5-3 \mathrm{~kg}$ with crown; irregular cylindrical; genetic shape defects common and more severe when fruits are large; flesh pale yellow to yellow, firm and sweet; SS $12 \%$; low acid; crown small; numerous crownlets protrude from base of crown and upper fruitlets. Plant: medium to tall; leaves completely smooth (piping); peduncle long, makes fruit susceptible to lodging and sunburn, particularly in hot lowlands; basal slips 4-11; susceptible to fruitlet core rot and the fly Melanoloma canopilosum; resistant to fusariosis.

Queen (Mauritius, Malacca, Red Ceylon, Buitenzorg, Victoria, Ripley Queen, Alexandra, Moris, McGregor, Z, James Queen). Widely distributed, hardy pineapple grown for fresh-fruit market mostly in tropical environments in the Southern Hemisphere. Origin: pre-Columbian, still found deep inland in French Guiana; the tetraploid genotype James Queen (formerly Z) was found in South Africa. Fruit: yellow; small, $0.5-1.0 \mathrm{~kg}$ with crown; conical to cylindrical, depending on clone; small prominent fruitlets; SS 14$18 \%$; relatively low acid; flesh sweet, crisp, golden yellow, with excellent flavor and long shelf life; very susceptible to internal browning, particularly if harvested before maturity. Plant: vigorous and robust; small, 60 to $80 \mathrm{~cm}$; leaves short and very spiny, silvery; slip and shoot numbers vary widely between clones; more tolerant to stress, pests and diseases than Smooth Cayenne; susceptible to natural floral induction, phytophthora rots, bacterial fruit collapse, fruitlet core rot (affected fruitlets remain green), and butt rot (Chalara paradoxa).

Selangor Green (Green Pine, Green Spanish, Nanas Hijau, Selassie). An important traditional cultivar. Origin: derived from 
a mutation of Singapore Spanish where the anthocyanins in all the organs are suppressed. Fruit: yellow; small, about $1.0 \mathrm{~kg}$, but heavier in some locations; cylindrical; SS 10-12\%; acidity low; taste poor, however juice is of good color and quality. Multiple crowns frequent. Plant: vigorous; medium, $80-100 \mathrm{~cm}$; leaves $35-$ 70 , uniformly green leaves and inflorescence while petals are pale yellow, $150 \times 5 \mathrm{~cm}$; leaves vary from completely spiny to very few spines, depending on clone; bracts of the peduncle and inflorescence bright red; produces 2-6 slips and many shoots; cultivated in South Asia, particularly in Malaysia, because it is well adapted to peat soils with high $\mathrm{pH}$; tolerant to phytophthora rots; susceptible to bacterial fruit collapse caused by Erwinia chrysanthemi and nematodes; develops severe chlorosis in high manganese soils.

Singapore Spanish (Singapore Canning, Ruby, Red Pine, Nanas Merah, Nangka, Gandul, Betek, Masmerah). Second-most important canning cultivar in the world. Origin: pre-Columbian. Fruit: dark purple, turning copper-orange when ripe; small, about $1.0 \mathrm{~kg}$, but heavier in some locations; cylindrical; flesh golden yellow; SS 10-12\%; acidity low; taste poor; however, juice is of good color and quality; multiple crowns frequent. Plant: vigorous; medium, 80-100 $\mathrm{cm}$; leaves 35-70, dark green, $150 \times 5 \mathrm{~cm}$; leaves vary from completely spiny to very few spines, depending on clone; bracts of the peduncle and inflorescence bright red; produces 2-6 slips and many shoots; cultivated in South Asia, particularly in Malaysia, because it is well adapted to peat soils with high $\mathrm{pH}$; tolerant to phytophthora rots; susceptible to bacterial fruit collapse and nematodes; develops severe chlorosis in high manganese soils.

Tainung No. 17 (Tainon 17). A yellow-fleshed pineapple with better flavor and lower acidity than Smooth Cayenne; holds about $80 \%$ of the fresh pineapple market share in Taiwan. Origin: Chiayi Agricultural Experiment Station, Chiayi, Taiwan, Taiwan Agricultural Research Institute, by C.-C. Chang. Smooth Cayenne x Queen; crossed 1980; selected 1991; tested as C69-4-381; introd. 1998. Fruit: yellow; medium, 1.4-1.5 kg with crown; cylindrical; skin thin; blossom cup shallow; flesh yellow to deep yellow, juicy; mildly acid; more fibrous than Smooth Cayenne; core large. Plant: moderately vigorous, average plant height $90 \mathrm{~cm}$; leaf edge smooth with spiny tips; susceptible to natural floral induction; moderately susceptible to mealybug wilt.

Vitória. The second cultivar introd. from the Brazilian hybridization program, with fusariosis resistance. Origin: EMBRAPA Cassava \& Tropical Fruits, Cruz das Almas, Brazil, by J.R.S. Cabral; crossed 1985; Primavera x Smooth Cayenne; tested as PRIxSC-08, later as EC-099 (Espirito Santo state, Brazil); introd. 2006. Fruit: yellow; medium, $1.5 \mathrm{~kg}$ with crown; crown $131 \mathrm{~g}$; cylindrical with flat fruitlets; fruit core thin, $12 \mathrm{~mm}$; flesh firm, white, with excellent flavor; SS $15.8 \%$; titratable acidity $0.8 \%$; more resistant to damage in transportation than Pérola and Smooth Cayenne. Plant: vigorous; habit similar to Pérola; 'D' leaf $92.8 \mathrm{~cm}$ long x $10.5 \mathrm{~cm}$ wide; leaves smooth (piping), light-green; peduncle thin, $20 \mathrm{~mm}$; slips 4.2; resistant to fusariosis.

\section{PISTACHIO}

\section{Dan E. Parfitt, Department of Plant Sciences, University of} California, Davis, CA

Golden Hills. High-yielding, high-percent-split, early maturing female Pistacia vera cultivar for harvest before Kerman. Origin: University of California, Davis, by D.E. Parfitt, C.E. Kallsen, and J. Maranto. 2-34 x ES\#21; crossed 1990; tested as B22-31; introd. 2005; USPP 17,158; 17 Oct. 2006. Flower: panicles with 50-200 female flowers borne laterally on 1-year-old wood, $2.5-4.0 \mathrm{~cm}$ long, expanding to $8 \mathrm{~cm}$; flowering period 3 weeks, $\approx 1$ week earlier than Kerman. Nut: in-shell size and shape are similar to Kerman, $\approx 1.3 \mathrm{~g}$; mature 1-2 weeks prior to Kerman; yield greater than for Kerman, percent split edible in-shell nuts greater than Kerman. Tree: structure typical for $P$. vera; $\approx 3 \mathrm{~m}$ tall and wide at 7 years, trunk diameter 10 $15 \mathrm{~cm}$; more and smaller scaffold branches than Kerman.

Kalehghouchi. High-yielding, female $P$. vera cultivar with large, high quality nuts which is more difficult to shake harvest than other cultivars. Origin: Iran. Flower: panicles with 50-200 female flowers borne laterally on 1-year-old wood; flowering period is $\approx 1$ week earlier than Kerman, similar to Golden Hills and Lost Hills. Tree: somewhat larger than Kerman; vigorous with many long branches; bears clusters on long, horizontal 1-year-old branches Nut: in-shell size and shape much larger than Kerman, $\approx 1.4 \mathrm{~g}$; higher percent split nuts than Kerman; harvest date and yield similar to Kerman; edible yield higher than Kerman.

Lost Hills. Early maturing, low-alternate-bearing, large nut, female $P$. vera cultivar for harvest before Kerman. Origin: University of California, Davis, by D.E. Parfitt, C.E. Kallsen, and J. Maranto. Introd. 2005; USPP 17,701; 8 May 2007. Flower: panicles with female flowers borne laterally on 1-year-old wood, $2.5-4 \mathrm{~cm}$ long, expanding to $8 \mathrm{~cm}$; 3 -week flowering period $\approx 1$ week earlier than Kerman. Nut: in-shell nuts are larger than Kerman, longer and less flattened with a deeper split in the shell, approx. $1.4 \mathrm{~g}$; ripens 1-2 weeks prior to Kerman; total yield similar to Kerman with less alternate bearing habit. Tree: structure typical for $P$. vera $; \approx 3 \mathrm{~m}$ tall and $3 \mathrm{~m}$ wide at 7 years, trunk diameter $12-18 \mathrm{~cm} \approx 15 \%$ larger than Kerman.

PETE I. Female $P$. vera cultivar with large nut and high level of resistance to Botryosphaeria dothidea, useful for higher rainfall areas. Origin. Pete I Pistachios, Inc., by D.R. Petersen; parents unknown; introd. 2007; USPP 17,836; 26 June 2007. Flower: bloom period 25 Mar.-10 Apr. in N. California. Nut: significantly larger than Kerman with deep suture; $90 \%$ split nuts. Tree: upright growth habit; high level of reported resistance to $B$. dothidea, approx. $5 \%$ of incidence of Kerman.

PG1. Seed-propagated $P$. integerrima hybrid rootstock for budding and grafting to $P$. vera scions. Origin: Pioneer Nursery by H.P. Anderson III and K.L. Puryear. $P$. integerrima female clone $\mathrm{x} P$. integerrima male clone (hybrid progeny are dioecious). Tree: parent and progeny trees morphologically typical of $P$. integerrima; large tree as unbudded rootstock; provides earlier fruiting, larger pistachio tree than traditional $P$. atlantica rootstock; resistant to verticillium wilt (Verticillium dahliae).

Randy. Male $P$. vera pollenizer for Golden Hills and Lost Hills. Origin: University of California, Davis, by D.E. Parfitt, J. Maranto, and C.E. Kallsen. Introd. 2005; USPP 18,262; 4 Dec. 2007. Flower: panicles with male flowers borne laterally on 1 year old wood, 2.5-4 $\mathrm{cm}$ long, expanding to $8 \mathrm{~cm}$; long flowering period, more and larger inflorescences than Peters male, more durable (viable) pollen than Peters, flowering period greater than 3 weeks, approx. 1 week earlier than Peters. Tree: structure and branching habit are typical for male $P$. vera $; \approx 3 \mathrm{~m}$ tall and $3 \mathrm{~m}$ wide at 7 years, trunk diameter $10-15 \mathrm{~cm}$ (larger than Peters); larger crown than female cultivars, similar to Peters.

Ruehle. Female $P$. vera cultivar with potentially better nut quality than Kerman. Origin: by E.C. Ruehle and A.J. Ruehle; probably Bronte O.P. Flower and Tree: similar to Kerman. Nut: Similar to Kerman, but larger kernel; less susceptible to epicarp lesion than Kerman.

UCB1. Seed propagated Pistacia hybrid rootstock for budding and grafting $P$. vera scions; Origin: University of California, Berkeley, by L.J. Ashworth and D.P. Morgan. P. atlantica female clone x $P$. integerrima male clone (hybrid progeny are dioecious); introd. c. 1992 by D.P. Morgan, L. Epstein, and L. Ferguson, University of California, Davis. Tree: large tree with upright growth habit, 2x size 
of $P$. atlantica; compound imparapinnate leaves similar to but intermediate in size to $P$. chinensis and $P$. integerrima with distinctive reddish color on new growth; provides earlier fruiting, larger pistachio tree than traditional $P$. atlantica rootstock; reported to be more cold tolerant than PG1, but less cold tolerant than $P$. atlantica species; resistant to verticillium wilt.

\section{PITANGA (SURINAM CHERRY)}

John L. Griffis, Jr., Department of Marine and Ecological Sciences, Florida Gulf Coast University, Ft. Myers, FL

Gitit. Origin: backyard seedling discovered in Naharia, northern Israel; selected 1997 by E. Lahav and E. Slor. Fruit: superior to Lolita, Necha, and 404; size varies depending on fruit set, 5-12 g; blood red; flavor varies from sweet-sour to sour-sweet, very mild in comparison to cultivars that possess strong, sharp flavors; flesh firm to soft according to the stage of ripeness.

Lorver. Origin: unknown. Fruit: large, about $2.5 \mathrm{~cm}$ diameter, 6.6 $\mathrm{g}$, up to $3.8 \mathrm{~cm}$ and more than $18 \mathrm{~g}$; skin bright red-orange at Montoso Gardens, Puerto Rico.

Vermillion. Origin: unknown. Fruit: large, more than $2.5 \mathrm{~cm}$ diameter, $7.3 \mathrm{~g}$; skin bright red-orange at Montoso Gardens, Puerto Rico.

Zill Dark. Origin: Introd. by Gary Zill of Zill High Performance Plants, Lake Worth, FL. Fruit: generally $2.5 \mathrm{~cm}$ or larger; skin dark purple ("black"); flavor sweet-sour, mild to moderate intensity and non-resinous compared to typical red-fruited seedlings; flesh firm to soft, depending on ripeness.

\section{PLANTAIN}

\section{Ricardo Goenaga, USDA-ARS, Tropical Agriculture Research Station, Mayaguez, PR}

Dominican Red. True plantain (M. acuminata x M. balbisiana $\mathrm{AAB}$ ). Origin: clonal selection from the Dominican Republic. Bunch: French type with 88 fruits; 7 hands; $28.8 \mathrm{~kg}$. Fruit: $327 \mathrm{~g}$. Pseudostem: red; tall, $3.5 \mathrm{~m}$; diameter $17.7 \mathrm{~cm}$.

FHIA 21. True plantain (M. acuminata x M. balbisiana AAAB). Origin: hybrid developed by Fundación Hondureña de Investigación Agrícola, Honduras. Bunch: French type with 102 fruits; 7 hands; $26.5 \mathrm{~kg}$. Fruit: 260 g. Pseudostem: tall, $3.5 \mathrm{~m}$; diameter $19.3 \mathrm{~cm}$; tolerant to black Sigatoka (Mycosphaerella fijiensis).

Maiden. True plantain (Musa acuminata x M. balbisiana AAB). Origin: clonal selection from SIAT SA, Honduras. Bunch: French type with having 84 fruits; 7 hands; $29.6 \mathrm{~kg}$. Fruit: $355 \mathrm{~g}$. Pseudostem: green; tall, $3.3 \mathrm{~m}$; diameter $18 \mathrm{~cm}$.

Superplantain. True plantain (M. acuminata x M. balbisiana AA). Origin: clonal selection by Heber Irizarry in Corozal, PR. Bunch: French type with 92 fruits; 7 hands; 26 kg. Fruit: 280 g. Pseudostem: tall, $3.5 \mathrm{~m}$; diameter $17.4 \mathrm{~cm}$.

\section{PLUM AND PLUM HYBRIDS}

David W. Ramming, USDA-ARS San Joaquin Valley Agricultural Sciences Center, Parlier, CA

Amigo I. Midseason, dark red skin, yellow-red flesh, interspecific plum. Origin: Modesto, CA, by G.N. Zaiger, L.M. Gardner, and G.G. Zaiger. 276LF278 interspecific x Crimson Glo plum; selected 2003. USPP 20,165; 7 July 2009. Fruit: medium, 58 mm diameter,
$117 \mathrm{~g}$; round; skin dark red, glabrous; flesh yellow-red; SS 16\%; clingstone; ripens 15-23 June, $6 \mathrm{~d}$ before Hiromi Red. Tree: large; vigorous; upright; productive, regular producer; self-infertile; anthers red-orange; petals white; blooms 18-27 Feb. in Modesto; chilling requirement $450 \mathrm{~h}$.

Apriplum III. Midseason, black-red skin, red and orange-yellow flesh, interspecific plum. Origin: Le Grand, CA, by L.G. Bradford. Black Noble plum x unknown apricot and interspecific pollen; crossed 2001; selected 2004. USPP 19,519; 2 Dec. 2008. Fruit: small, $54 \mathrm{~mm}$ diameter, $91 \mathrm{~g}$; round; skin black-red, glabrous; flesh red and orange-yellow, SS 25\%; apricot flavor; clingstone; ripens 1-14 July. Tree: medium; medium vigor; upright; productive, uncertain producer; self-infertile; anthers pale yellow-green, pollen very little; petals white; blooms midseason, 2-9 Mar. in Le Grand, 2 d after Santa Rosa.

Apriplum VII. Late-season, black-red skin, red-orange flesh, interspecific plum. Origin: Le Grand, CA, by L.G. Bradford. 7P1017 interspecific plum $\mathrm{x}$ unknown apricot, plum and interspecific pollen; crossed 2000; selected 2004. USPP 19,529; 2 Dec. 2008. Fruit: small-medium, $54 \mathrm{~mm}$ diameter, $91 \mathrm{~g}$; ovate; skin black-red, glabrous; flesh red to red orange; SS 20-24\%; apricot flavor; clingstone; ripens 18-28 Aug. Tree: medium; vigorous; upright; very productive, regular producer; self-infertile; anthers yellow; petals white; blooms midseason, 3-9 Mar. in Le Grand, $3 \mathrm{~d}$ after Santa Rosa.

Black Majesty. Late-season, black skin, orange-yellow flesh, Japanese plum. Origin: Le Grand, CA, by L.G. Bradford. 42P1156 plum x unknown pollen; crossed 1998; selected 2003. USPP 19,527; 2 Dec. 2008. Fruit: medium, $61 \mathrm{~mm}$ diameter, $139 \mathrm{~g}$; globose with small point; skin black, glabrous; flesh orange-yellow; SS 23\%; clingstone; ripens 1-15 Sept. Tree: medium; vigorous; upright; productive, regular producer; self-infertile; anthers orangeyellow; petals white; blooms midseason, 28 Feb.-6 Mar. in Le Grand

Blackred I. Early-season, black skin, red flesh, interspecific plum. Origin: Le Grand, CA, by L.G. Bradford. Purple Majesty x unknown apricot and interspecific pollen; crossed 2001; selected 2004. USPP 19,537; 2 Dec. 2008. Fruit: medium, 60 mm diameter, 116 g; oblate; skin black, glabrous; flesh red; SS 15-18\%; clingstone; ripens 1-12 June. Tree: medium; vigorous; upright; very productive, regular producer; self-infertile; anthers orange-yellow; petals white; blooms early-season, 19 Feb.-2 Mar. in Le Grand, 3 d before Ambra.

Blackred II. Midseason, dark purple-red skin, red flesh, interspecific plum. Origin: Le Grand, CA, by L.G. Bradford. 19P442 red plum x unknown apricot and interspecific pollen; crossed 2001; selected 2004. USPP 19,827; 17 Mar. 2009. Fruit: medium, 62 mm diameter, $125 \mathrm{~g}$; round to oblate; skin dark purple-red, glabrous; flesh red; SS 15-19\%; clingstone; ripe 9-20 June. Tree: large; vigorous; upright; very productive, regular producer; self-infertile; anthers orangeyellow; petals white; blooms early-season, 20-28 Feb. in Le Grand, $2 \mathrm{~d}$ before Ambra.

Blackred III. Mid- to late- season, black skin, yellow-red flesh, interspecific plum. Origin: Le Grand, CA, by L.G. Bradford Unnamed red plum $\mathrm{x}$ unknown apricot and interspecific pollen; crossed 2001; selected 2004. USPP 18,668; 25 Mar. 2008. Fruit: large, $72 \mathrm{~mm}$ diameter, $196 \mathrm{~g}$; ovate to round; skin black, glabrous; flesh yellow-red; SS 18-20\%; clingstone; ripens 29 July-10 Aug. Tree: medium; medium vigor; spreading; productive, regular producer; self-infertile; anthers red-orange; petals white; blooms earlyseason, with Ambra.

Blackred V. Midseason, black-red skin, dark red flesh, interspecific plum. Origin: Le Grand, CA, by L.G. Bradford. 19P442 red plum x unknown apricot and interspecific pollen; crossed 2001; selected 
2004. USPP 19,576; 16 Dec. 2008. Fruit: medium, $61 \mathrm{~mm}$ diameter, $122 \mathrm{~g}$; round to obovate; skin black-red, glabrous; flesh dark red, SS 22\%; clingstone; ripens 30 June-10 July. Tree: medium; vigorous; upright; very productive, regular producer; self-infertile; anthers deep orange-yellow; petals white; blooms early to midseason, 24 Feb.-4 Mar. in Le Grand, 2 d after Ambra.

Coparose. Midseason, dark red skin, yellow-red flesh, interspecific plum. Origin: Modesto, CA, by G.N. Zaiger, L.M. Gardner, and G.G. Zaiger. 276LF278 plum x Crimson Heart interspecific; selected 2003. USPP 20,173; 7 July 2009. Fruit: medium, $62 \mathrm{~mm}$ diameter, $125 \mathrm{~g}$; oblate; skin dark red, glabrous; flesh yellow-red; SS 15\%; clingstone; ripens 1-9 July, $10 \mathrm{~d}$ after Royal Zee. Tree: large; vigorous; upright; productive, regular producer; self-infertile; anthers yellow; petals white; blooms 28 Feb.-7 Mar. in Modesto; chilling requirement $750 \mathrm{~h}$.

\section{Crimson Pointe ${ }^{\top M}$. See Cripoizam.}

Crimson Royale. Mid- to late-season, red skin, yellow flesh, interspecific plum. Origin: Modesto, CA, by G.N. Zaiger, L.M. Gardner, and G.G. Zaiger. Flavor Grenade interspecific O.P.; selected 1999. USPP 18,559; 4 Mar. 2008. Fruit: large, $63 \mathrm{~mm}$ diameter, 185 g; elongated; skin red, glabrous; flesh yellow; SS 23\%; clingstone; ripens 29 July-7 Aug. Tree: large; vigorous; upright; productive, regular producer; self-infertile; anthers yellow; petals white; blooms 18 Feb.-1 Mar. in Modesto; chilling requirement $550 \mathrm{~h}$.

Cripoizam (Crimson Pointe ${ }^{\mathrm{TM}}$ ). Red leaf, P. cerasifera, ornamental plum. Origin: Perry, OH, by J.W. Zampini. Supposed Newport O.P. USPP 19,564; 9 Dec. 2008. Fruit: small, $25 \mathrm{~mm}$ diameter; skin red. Tree: very upright; sparse production; leaf deep purple; anthers yellow-orange; petals white; hardy in USDA Hardiness Zone 4.

Dapple Jack. Midseason, red skin, red flesh, interspecific plum. Origin: Modesto, CA, by G.N. Zaiger, L.M. Gardner, and G.G. Zaiger. 20Z62 interspecific O.P.; selected 2000. USPP 18,178; 6 Nov. 2007. Fruit: large, $62 \mathrm{~mm}$ diameter, $145 \mathrm{~g}$; round; skin red, glabrous; flesh red, 21\%; clingstone; ripens 7-12 July. Tree: large; vigorous; upright; productive, regular producer; self-infertile; anthers yellow; petals white; blooms 24 Feb.-3 Mar. in Modesto; chilling requirement $700 \mathrm{~h}$.

Gypzee. Late-season, dark red skin, yellow flesh, interspecific plum. Origin: Modesto, CA, by G.N. Zaiger, L.M. Gardner, and G.G. Zaiger. 321LH456 interspecific O.P.; selected 1999. USPP 19,834; 17 Mar. 2009. Fruit: large, $68 \mathrm{~mm}$ diameter, $190 \mathrm{~g}$; round to slightly elongated; skin dark red, glabrous; flesh yellow; SS 17\%; clingstone; ripens 1-8 Aug. Tree: large; vigorous; upright; productive, regular producer; self-infertile; anthers yellow-red; petals white; blooms 27 Feb.-8 Mar. in Modesto; chilling requirement $900 \mathrm{~h}$.

Honey Punch. Late-season, red skin, red flesh, interspecific plum. Origin: Modesto, CA, by G.N. Zaiger, L.M. Gardner, and G.G. Zaiger. Q22594A plum seedling x 20Z288 interspecific; selected 2003. USPP 19,596; 23 Dec. 2008. Fruit: medium-large, $67 \mathrm{~mm}$ diameter, $165 \mathrm{~g}$; round; skin red, glabrous; flesh red; SS 19\%; clingstone; ripens 11-18 Aug. Tree: large; vigorous; upright; productive, regular producer; self-infertile; anthers yellow; petals white; blooms 23 Feb.-3 Mar. in Modesto; chilling requirement $850 \mathrm{~h}$.

Honey Red. Very early season, bright red skin, yellow flesh, Japanese plum. Origin: Suwon, South Korea by J.H. Jun, K.H. Chung, S.J. Kang, Y.B. Kwack, K.S. Park, H.K. Yun, and S.B. Jeong. Oishiwase x Santa Rosa; crossed 1992; selected 1997; tested as 92Oishiwase*SantaRosa43-2; introd. 2002. Fruit: small, $49 \mathrm{~mm}$ diameter, $60 \mathrm{~g}$; round; skin bright red, glabrous; flesh yellow; SS 13\%; semi-freestone; ripens early July with Oishiwase. Tree: medium vigor; semi-upright; productive; self-infertile; blooms $2 \mathrm{~d}$ after Oishiwase; more susceptible to bacterial leaf spot (Xanthomonas campestris pv. Pruni). than Oishiwase.

Nadia. Midseason, dark red to purple skin, dark red flesh, interspecific plum. Origin: Shepparton, Victoria, Australia, by J. Rullo. Blackamber plum x Supreme cherry. USPP 19,842; 24 Mar. 2009. Fruit: small, $42-48 \mathrm{~mm}$ diameter, $60 \mathrm{~g}$; cordate; skin dark red to purple, glabrous; flesh dark red; SS 20-24\%; semi-clingstone; ripens 5-10 Jan. in Shepparton, Victoria. Tree: large; medium vigor; semi-upright; blooms 25 July-8 Aug. in Manjimup, Western Australia.

Plumgiant I. Mid- to late-season, black skin, light yellow-white flesh, Japanese plum. Origin: Le Grand, CA, by L.G. Bradford. Unnamed plum O.P.; crossed 2000; selected 2003. USPP 18,705; 1 Apr. 2008. Fruit: very large, $76 \mathrm{~mm}$ diameter, $213 \mathrm{~g}$; round; skin black, glabrous, slight tendency to crack; flesh light yellow-white; SS 18-20\%; clingstone; ripens 3-15 Aug., 7 d before August Yummy ${ }^{\circledR}$. Tree: medium; vigorous; upright; very productive, regular producer; self-infertile; anthers pale yellow-pink; petals white; blooms midseason, 24 Feb.-11 Mar. in Le Grand.

Plumred I. Midseason, dark red skin, yellow-pink with red flesh, interspecific plum. Origin: Le Grand, CA, by L.G. Bradford. 36P645 plum x unknown apricot and interspecific pollen; crossed 2001; selected 2004. USPP 18,665; 25 Mar. 2008. Fruit: large, $71 \mathrm{~mm}$ diameter, $190 \mathrm{~g}$; obovate to ovate; skin dark red, glabrous; flesh yellow-pink with red; SS 19\%; clingstone; ripens 30 June-10 July. Tree: large; medium vigor; spreading; medium productive, uncertain producer; self-infertile; anthers light yellow; petals white; blooms midseason, 18 Feb.-3 Mar. in Le Grand, 5 d after Blackamber.

Plumred X. Late-season, red skin, red flesh, interspecific plum. Origin: Le Grand, CA, by L.G. Bradford. 42P1156 purple plum x unknown apricot and interspecific pollen; crossed 2003; selected 2006. USPP 19,591; 23 Dec. 2008. Fruit: large, $73 \mathrm{~mm}$ diameter, $201 \mathrm{~g}$; round; skin red with yellow mottling, glabrous; flesh red; SS 20\%; clingstone; ripens 28 Aug.-10 Sept. Tree: medium-large; vigorous; upright; very productive, regular producer; self-infertile; anthers deep orange-yellow; petals white; blooms midseason, 1-7 Mar. in Le Grand, 1 d after Santa Rosa.

Plumsweet VI. Early season, red to reddish-orange skin, pink-red flesh, interspecific plum. Origin: Le Grand, CA, by L.G. Bradford Yummy ${ }^{\circledR}$ gem plum $\mathrm{x}$ unknown apricot and interspecific pollen; crossed 2001; selected 2004. USPP 18,687; 1 Apr. 2008. Fruit: medium, $60 \mathrm{~mm}$ diameter, $116 \mathrm{~g}$; oblate; skin red to reddish-orange, glabrous; flesh pink-red; SS 17-20\%; clingstone; ripens 20-30 June. Tree: large; vigorous; spreading; medium productive, uncertain producer; self-infertile; anthers light yellow; petals white; blooms early to midseason, 17-27 Feb. in Le Grand.

Plumsweet VII. Midseason, red skin, pink to red flesh, interspecific plum. Origin: Le Grand, CA, by L.G. Bradford. Unnamed red plum $\mathrm{x}$ unknown apricot and interspecific pollen; crossed 2001; selected 2004. USPP 18,667; 25 Mar. 2008. Fruit: medium, 65 mm diameter, $153 \mathrm{~g}$; oblate; skin red, glabrous; flesh pink to red; SS 19\%; clingstone; ripens 26 June-10 July. Tree: large; vigorous; spreading; medium productive, uncertain producer; self-infertile; anthers yellow; petals white; blooms early season, 14-26 Feb. in Le Grand, 2 d after Ambra.

Plumsweet VIII. Late-season, red and green skin, red-pink flesh, interspecific plum. Origin: Le Grand, CA, by L.G. Bradford. Unnamed red plum $\mathrm{x}$ unknown apricot and interspecific pollen; crossed 2001; selected 2004. USPP 18,670; 25 Mar. 2008. Fruit: medium, $65 \mathrm{~mm}$ diameter, $145 \mathrm{~g}$; round to oblate; skin red and green, 
glabrous; flesh red-pink; SS 20-24\%; clingstone; ripens 10-20 Aug. Tree: medium; medium vigor; spreading; medium productive, uncertain producer; self-infertile; anthers light yellow; petals white; blooms midseason, 20 Feb.-6 Mar. in Le Grand.

Plumsweet IX. Late-season, red-orange mottled over yellow skin, yellow to red flesh, interspecific plum. Origin: Le Grand, CA, by L.G. Bradford. Bradgreen plum x unknown apricot and interspecific pollen; crossed 1999; selected 2002. USPP 18,666; 25 Mar. 2008. Fruit: large, $72 \mathrm{~mm}$ diameter, $193 \mathrm{~g}$; round to ovate; skin red-orange mottled over yellow, glabrous; flesh yellow to red; SS 18-20\%; semifreestone; ripens 24 Aug.-4 Sept. Tree: medium; medium vigor; spreading; productive, regular producer; self-infertile; anthers yellow; petals white; blooms mid- to late-season, 1-12 Mar. in Le Grand, 2 d after Santa Rosa.

Plumsweet X. Midseason, dark red skin, dark red flesh, interspecific plum. Origin: Le Grand, CA, by L.G. Bradford. Yummy ${ }^{\circledR}$ gem plum x unknown apricot and interspecific pollen; crossed 2001; selected 2004. USPP 19,528; 2 Dec. 2008. Fruit: medium, $62 \mathrm{~mm}$ diameter, $150 \mathrm{~g}$; round; skin dark red with dark greenish-yellow mottling, glabrous; flesh dark red; SS 18-20\%; clingstone; ripens 23 June-7 July. Tree: medium; vigorous; upright; very productive, regular producer; self-infertile; anthers yellow; petals white; blooms midseason, 26 Feb.-4 Mar. in Le Grand, 2 d before Santa Rosa.

Plumsweet XI. Midseason, red skin, red-yellow flesh, interspecific plum. Origin: Le Grand, CA, by L.G. Bradford. Unknown green plum O.P. near apricot and interspecific trees; crossed 2003; selected 2006. USPP 19,796; 3 Mar. 2009. Fruit: medium-large, $62 \mathrm{~mm}$ diameter, $145 \mathrm{~g}$; oblate; skin red with orange-yellow speckles, glabrous; flesh red-yellow; SS 22\%; clingstone; ripens 1-17 July. Tree: medium-large; vigorous; upright; very productive, regular producer; self-infertile; anthers yellow; petals white; blooms earlyseason, 17 Feb.-3 Mar. in Le Grand, $5 \mathrm{~d}$ before Ambra.

Plumsweet XII. Midseason, red skin, dark red flesh, interspecific plum. Origin: Le Grand, CA, by L.G. Bradford. 19P442 red plum x unknown apricot and interspecific pollen; crossed 2001; selected 2004. USPP 20,106; 16 June 2009. Fruit: medium, $60 \mathrm{~mm}$ diameter, $125 \mathrm{~g}$; round to oblate; skin red with greenish-yellow speckles, glabrous; flesh dark red; SS 20\%; clingstone; ripens 7-17 July. Tree: medium; medium vigor; upright; medium production, regular producer; self-infertile; anthers light greenish-yellow, pollen slight; petals white; blooms midseason, 26 Feb.-6 Mar. in Le Grand, 2 d before Santa Rosa.

Plumsweet XIII. midseason, red skin, red to orange-yellow flesh, interspecific plum. Origin: Le Grand, CA, by L.G. Bradford. Yummy ${ }^{\circledR}$ gem x unknown apricot and interspecific pollen; crossed 2001; selected 2004. USPP 19,530; 2 Dec. 2008. Fruit: medium, 65 $\mathrm{mm}$ diameter, $156 \mathrm{~g}$; oblate; skin red over yellow background, glabrous; flesh red to orange-yellow; SS 20\%; clingstone; ripens 1123 July. Tree: medium; vigorous; upright; very productive, uncertain bearer; self-infertile; anthers yellow; petals white; blooms early-season, 17 Feb.-3 Mar. in Le Grand, $5 \mathrm{~d}$ before Ambra.

Queen Garnet. Midseason, dark red to black skin, dark red flesh, Japanese plum. Origin: Dept. Primary Industries \& Forestry, Brisbane, Australia, by D.M. Russel and B. Topp. (Blackamber x Amber Jewel) x O.P.; selected 2001; tested as GB403-39. USPP 19,630; 20 Jan. 2009. Fruit: medium to large, $60 \mathrm{~mm}$ diameter, 114 $\mathrm{g}$; round to ovate; skin dark red to black, glabrous; flesh dark red with high anthocyanins; SS 17-21\%; semi-freestone; ripens $14 \mathrm{~d}$ after Friar. Tree: medium-large, moderate vigor; semi-spreading; precocious and productive; self-infertile; anthers yellow-orange; petals white; blooms early to midseason, with Blackamber and Santa Rosa; chilling requirement about $700 \mathrm{~h}$; resistant to bacterial spot.
REDYUMMY.RTM (Red Yummy $\left.{ }^{\circledR}\right)$. Late-season, red skin, yellow flesh, Japanese plum. Origin: Le Grand, CA, by L.G. Bradford. Unnamed red plum x unknown pollen; crossed 2001; selected 2004. USPP 18,663; 25 Mar. 2008. Fruit: medium large, $71 \mathrm{~mm}$ diameter, $193 \mathrm{~g}$; round to oblong; skin red, glabrous; flesh yellow, 21\%; clingstone; ripens 22 Aug.-7 Sept. Tree: large; vigorous; upright; productive, regular producer; self-infertile; anthers brilliant yellow; petals white; blooms midseason, 20 Feb.-4 Mar. in Le Grand.

\section{Red Yummy ${ }^{\circledR}$. See REDYUMMY.RTM.}

Ruby Kat. Midseason, red skin, red fleshed, interspecific plum. Origin: Modesto, CA, by G.N. Zaiger, L.M. Gardner, and G.G. Zaiger. Flavor Jewel interspecific x Emerald Beaut plum; selected 2004. USPP 19,619; 6 Jan. 2009. Fruit: large, 67 mm diameter, 205 g; round; skin red, glabrous; flesh red; SS 19\%; clingstone; ripens 1524 July. Tree: large; vigorous; upright; productive, regular producer; self-infertile; anthers yellow; petals white; blooms 1-11 Mar. in Modesto; chilling requirement $800 \mathrm{~h}$.

Suplumthirtyeight. Very early-season, black skin, amber flesh, Japanese plum. Origin: Sun World International, LLC, Bakersfield, CA, by D.W. Cain and T.A. Bacon. 92P037-130-001 x Suplumtwenty; crossed 1997; selected 2000; tested as 97P047-010-311. USPP 18,739; 22 Apr. 2008. Fruit: medium, 58 mm diameter, 108 g; round; skin black, glabrous; flesh amber; SS 15\%; clingstone; ripens 12-20 May, $10 \mathrm{~d}$ before Red Beaut. Tree: medium; moderate vigor; upright-spreading; productive, regular producer; anthers yellow; petals white; blooms 5-10 Feb. in Wasco, CA, with Black Beaut; chilling requirement $300 \mathrm{~h}$.

Suplumthirtyone. Midseason, yellow skin, yellow flesh, Japanese plum. Origin: Sun World International, LLC, Bakersfield, CA, by T.A. Bacon, B.D. Mowrey, and D.W. Cain. 90P-059 x 232-205; crossed 1993; selected 1996; tested as 93P062-119-187. USPP 19,064; 5 Aug. 2008. Fruit: large, $65 \mathrm{~mm}$ diameter, $153 \mathrm{~g}$; round to elongate with extended apex; skin yellow, glabrous; flesh yellow; SS 18\%; clingstone; ripens 22 July-5 Aug. Tree: medium; vigorous; upright-spreading; productive, regular producer; anthers yelloworange; petals white; blooms 25-28 Feb. in Wasco, CA; chilling requirement $600 \mathrm{~h}$.

Suplumthirtyseven. Early-season, purple-black skin, orange-red flesh, Japanese plum. Origin: Sun World International, LLC, Bakersfield, CA, by T.A. Bacon and D.W. Cain. 92PC003-126118 x O.P.; crossed 1997; selected 2000; tested as 97PC016-009505. USPP 18,690; 1 Apr. 2008. Fruit: medium, $61 \mathrm{~mm}$ diameter, $112 \mathrm{~g}$; round; skin purple-black, glabrous; flesh orange-red; SS 17\%; clingstone; ripens 24 May-1 June, 7 d before Black Beaut. Tree: medium; moderate vigor; upright-spreading; productive, regular producer; anthers orange; petals white; blooms 24 Feb. in Wasco, $\mathrm{CA}$; chilling requirement $650 \mathrm{~h}$.

Suplumthirtysix. Late-season, red-black skin, amber flesh, Japanese plum. Origin: Sun World International, LLC, Bakersfield, CA, by T.A. Bacon, and D.W. Cain. 90P-072 x 90P-070; crossed 1996; selected 1999. USPP 19,023; 15 July 2008. Fruit: large, $70 \mathrm{~mm}$ diameter, $195 \mathrm{~g}$; elongate with prominent tip; skin red-black, glabrous; flesh amber; SS 19\%; clingstone; ripens 14-25 Aug., with Angelino. Tree: medium; vigorous; upright-spreading; productive, regular producer; anthers yellow; petals white; blooms 15 Mar. in Wasco, CA; chilling requirement $750 \mathrm{~h}$.

Yellowsweet II. Mid late-season, yellow skin, orange-yellow flesh, interspecific plum. Origin: Le Grand, CA, by L.G. Bradford. Yummy ${ }^{\circledR}$ gem plum $\mathrm{x}$ unknown apricot and interspecific pollen; crossed 2001; selected 2004. USPP 19,518; 2 Dec. 2008. Fruit: medium, $62 \mathrm{~mm}$ diameter, $136 \mathrm{~g}$; round to ovoid; skin black-red, glabrous; flesh orange-yellow, 22-24\%; clingstone; ripens 3-17 Aug. 
Tree: medium; vigorous; upright; very productive, regular producer; self-infertile; anthers orange-yellow; petals white; blooms midseason, $2 \mathrm{~d}$ before Santa Rosa.

Yellowsweet X. Late-season, yellow skin, light yellow flesh, interspecific plum. Origin: Le Grand, CA, by L.G. Bradford. Bradgreen plum $\mathrm{x}$ unknown apricot, and interspecific pollen; crossed 1997; selected 2000. USPP 18,669; 25 Mar. 2008. Fruit: medium, $67 \mathrm{~mm}$ diameter, $181 \mathrm{~g}$; round; skin yellow, glabrous; flesh light yellow; SS 18\%; clingstone; ripens 15-25 Aug. Tree: medium; medium vigor; spreading; very productive, regular producer; selfinfertile; anthers orange-yellow; petals white; blooms early to midseason, 15 Feb.-5 Mar. in Le Grand, $2 \mathrm{~d}$ after Blackamber.

\section{PLUM ROOTSTOCK}

\section{Thomas G. Beckman, USDA-ARS Southeastern Fruit and Tree Nut Research Laboratory, Byron, GA}

Greenpac. Compatible with some Japanese plum cultivars (limited testing). Described under Peach Rootstock.

\section{POMEGRANATE}

\section{Todd Kennedy, Esq., attorney in private practice, San Francisco,} CA

Ambrosia. Useful and large, all-purpose pomegranate. Origin: Camarillo, CA, by S.J. Chater, c. 1985; probable sibling of Eversweet. Fruit: very large, to $13 \mathrm{~cm}$ in diameter; flattened at apex, calyx elongated, closed; yellow, irregularly marbled with red; carpels large, aril red; subacid to decidedly acid, but sweeter than Wonderful; juice yield good, pale red; fruit suitable for juice or fresh use, though too tart for some; seed large, nearly soft; ripens 2-3 weeks before Wonderful at Davis, CA. Tree: readily propagated by hardwood cuttings; growth rapid; rather unbranching; productive.

Cloud. Low-acid pomegranate for fresh use. Origin: collected by staff of California Agricultural Experiment Station, established at Winters, CA 1954-1960, by J. Lovell, California State University, Hayward, 1983. Fruit: medium to large, to $9 \mathrm{~cm}$ in diameter; 4-5 sided; calyx elongated, closed; white with very slight marbling of rose pink over most of fruit; carpels large, aril white, stippled pink on exterior, otherwise unpigmented; sweet and low in acid; juice uncolored, yield good, useful for blending with too-highly flavored juices; seeds large, nearly soft; ripens 3-4 weeks before Wonderful at Davis, CA. Tree: readily propagated by hardwood cuttings; flowers unshowy, pale buff; leaves die to white or pale yellow in autumn.

Crab (Red Silk $\left.{ }^{\mathrm{TM}}\right)$. High-acid pomegranate for juice and culinary uses. Origin: collected by staff of California Agricultural Experiment Station, established at Winters 1954-1960, by J. Lovell, California State University, Hayward, 1983. Fruit: medium, to $8.5 \mathrm{~cm}$ in diameter; pronounced 5-sided form; calyx spreading; pale yellow, washed pale pink with streaks and patches of coarse red stipple; carpels large, aril black-red; quite tart, not lessened with maturity, quite astringent; fair juice yield, juice black-red; seeds hard; type used in Central Asian cookery; useful for acidifying or coloring juices, but astringency objectionable; ripens soon after Wonderful at Davis, CA. Tree: readily propagated by hardwood cuttings; little branching; spiny; flowers showy, semi-double; leaves dark green.

Cranberry. High-acid pomegranate suitable for fresh use. Origin: collected by staff of California Agricultural Experiment Station, established at Winters 1954-1960, by J. Lovell, California State University, Hayward, 1983. Fruit: medium, to $7.5 \mathrm{~cm}$ in diameter, irregular, 5-sided; calyx long, spreading; pale pink, streaked red; carpels large; arils purple-red; subacid to decidedly acid, good sugar content, juice very dark red, good yield; seeds small, comprise low proportion of flesh; useful for blending, but attractive to some unblended; used in Central Asian cookery; ripens 2 weeks after Wonderful at Davis, CA. Tree: readily propagated by hardwood cuttings; dense grower; rather spiny.

Dewey. Low-acid pomegranate for fresh use or unblended juice. Origin: collected by staff of California Agricultural Experiment Station, established at Winters 1954-1960, by J. Lovell, California State University, Hayward, 1983. Fruit: medium, to $8 \mathrm{~cm}$ in diameter; 5-sided; calyx short, spreading; white washed with pale pink, streaked and marbled red except near apex; carpels large; aril pale red, white at base, texture remains firm and crisp for long; sweet, slight acid; juice pink, yield good; useful as an unblended juice; seeds large, hard; ripens with Wonderful at Davis, CA. Tree: readily propagated by hardwood cuttings; a dense and strong grower; flowers showy, semi-double.

Eve. Well-flavored, medium-acid pomegranate for fresh use or unblended juice. Origin: collected by staff of California Agricultural Experiment Station, established at Winters 1954-1960, by J. Lovell, California State University, Hayward, 1983. Resembles Saveh. Fruit: large, to $9.6 \mathrm{~cm}$ in diameter; slightly oblate, 5-sided; calyx spreading; pale pink, streaked and marbled with red over entirety; carpels large; aril dark red, acidulous; juice red, copious; seeds large, hard; ripens 2 weeks after Wonderful at Davis. Tree: poorly propagated by hardwood cuttings, better by tissue culture; nearly spineless; flowers showy, semi-double.

Kashmir Blend ${ }^{\mathrm{TM}}$. See Sour.

Mae. Low-acid pomegranate for fresh use or unblended juice. Origin: collected by staff of California Agricultural Experiment Station, established at Winters 1954-1960, by J. Lovell, California State University, Hayward, 1983. Fruit: large, to $9.4 \mathrm{~cm}$ in diameter; true globe; calyx half-long, closed; dull pink marbled with red throughout, lenticels many, rough and brown; carpels large, aril dark red, texture remains firm and crisp for long; sweet, rather rich, almost low-acid; juice dark red, not very copious, but good unblended; seeds large, not soft; ripens 1 week before Wonderful at Davis, CA. Tree: poorly propagated from hardwood cuttings, better by tissue culture; flowers showy, semidouble.

Parfianka (Garnet Sash). Sweet-acid, semi-hard seeded and highly colored pomegranate for fresh and juice use. Origin: traditional cultivar from Central Asia; selected by O.F. Mizgiryova, N.I. Zaktrager, and A.D. Strebkova, VIR Kara-Kala Experiment Station, Turkmenistan; introd. from Garrygala Experiment Station, Turkmenistan to USDA-ARS National Clonal Germplasm Repository, Davis, CA in 2004. Fruit: large to very large, to $13 \mathrm{~cm}$ in diameter; slightly pointed at apex; calyx erect; dark red, coloring uniform; aril large, dark red; sweet and lightly tart; seeds comprise low proportion of flesh, semi-soft, edible; juice dark red; ripens with or slightly before Wonderful at Davis. Tree: readily propagated by hardwood cuttings; moderately dense growth; few spines except at terminals; flowers large, showy, semi-double; fruits easily harvested.

Pink Ice. See Sin Pepe.

Pink Satin ${ }^{\mathrm{TM}}$. See Sin Pepe.

Red Silk ${ }^{\mathrm{TM}}$. See Crab.

Sin Pepe (Pink Ice, Pink Satin ${ }^{\mathrm{TM}}$ ). Traditional, soft-seeded pale pomegranate for fresh use. Origin: cultivar of long standing in western Mediterranean, first reputed introduction c. 1880, possibly by Felix Gillet, Nevada City, CA. Fruit: large, to $11 \mathrm{~cm}$ in diameter; flattened at apex; calyx erect; ivory, incompletely covered with pale pink; carpels few, separated by wide sectors of pith, aril pale red, 
large; flavor bland and sweet; seeds comprise low proportion of flesh, are edible, unnoticeable by some, hence name; juice pink; ripens 3-4 weeks before Wonderful at Davis, CA. Tree: readily propagated by hardwood cuttings; rather open; somewhat spiny; flowers large, showy, semi-double.

Sour (Kashmir Blend ${ }^{\mathrm{TM}}$ ). Pomegranate for juice and culinary uses. Origin: collected by staff of California Agricultural Experiment Station, established at Winters 1954-1960 by J. Lovell, California State University, Hayward, 1983. Fruit: medium, to $8 \mathrm{~cm}$ in diameter; pronounced 4-sided form; calyx slightly spreading; pale pink streaked with red, solid red on insolation, many russet lenticels; carpels small, aril brilliant red; acid; not highly productive of juice, juice dark red, sour; seeds hard; used in Central Asian cookery, useful for acidifying or coloring juices; ripens soon after Wonderful at Davis, CA; acidity decays with storage. Tree: readily propagated by hardwood cuttings; leaves dark green.

\section{RASPBERRY}

Patrick P. Moore, Horticulture and Landscape Architecture Department, Washington State University, Puyallup, WA

Chaim Kempler, Agriculture and Agri-Food Canada, Pacific AgriFood Research Center, Agassiz, BC, Canada

Adele. A midseason, floricane-fruiting red raspberry producing good yields of high quality fruit suited to fresh markets. Origin: Plant and Food Research Limited, Motueka, New Zealand, by M.J. Stephens and H.K. Hall. Chilcotin x 86107O58; crossed 1990; selected 1994; tested as HR119; introd. 2008. USPP pending. Fruit: medium; moderate firmness; good flavor; suited to hand picking. Plant: semispineless; upright canes; strong vigor; adapted to low winter chill conditions such as Motueka, New Zealand; resistant to Raspberry bushy dwarf virus (RBDV).

Autumn Treasure. A midseason, primocane-fruiting red raspberry for fresh production suitable for low input systems and protected cultivation. Origin: East Malling Research, Kent, United Kingdom, by V.H. Knight. EM6304/36 × EM6330/96; crossed 1995; selected 1999; tested as EM 6597/46; introd. 2007. USPP applied for. Fruit: medium to large; firm; pleasant flavor; bright red; long conical; ripens 10-14 d after Autumn Bliss; detaches easily from the receptacle; good shelf-life; low incidence of postharvest rot in unsprayed plots. Plant: spine-free; upright; fruit produced in short laterals on the top half of the canes; well presented to pickers; resistant to biotypes 1-4 of the large raspberry aphid (Amphorophora idaei); highly resistant to phytophthora root rot (Phytophthora rubi); higher tolerance to verticillium wilt (Verticillium dahliae) than other primocane-fruiting cultivars.

Awaroa. An early, floricane-fruiting red raspberry producing good yields of high quality fruit suited to fresh markets. Origin: Plant and Food Research Limited, Motueka, New Zealand, by M.J. Stephens and H.K. Hall. 86105N26 x 87115ZN2; crossed 1991; selected 1994; tested as HR137; introd. 2008. USPP pending. Fruit: medium; moderate firmness; moderate flavor; removes easily from receptacle; suited to hand pick and machine harvesting; ripens early season; some primocane crop. Plant: good vigor; spineless; upright canes; adapted to low winter chill conditions such as Motueka, New Zealand; resistant to RBDV; susceptible to phytophthora root rot.

Bethan. A high-yielding, primocane-fruiting red raspberry. Origin: Medway Fruits, United Kingdom, by D. Jennings. Marcela x Joan Irene; crossed 2001; tested as 13/10; introd. 2007. Fruit: typically over $6 \mathrm{~g}$; firm; bright red; sweet; easily removed from receptacle; cohesive. Plants: vigorous; susceptible to all strains of Amphorophora species.

Frutafri (Tula Magic ${ }^{\circledR}$ ). A productive, midseason, fresh-market red raspberry. Origin: R. Neuweiler, Truttikon, Switzerland. Autumn
Bliss x Tulameen. EU PVR applied for. Fruit: large, comparable to Tulameen; very firm; light red; good shelf life; intense aroma; high sugar content; hand picks easily; floricane crop ripens approximately one week earlier than Tulameen; under mild climactic conditions or under tunnel can produce primocane crop. Plant: vigorous; sparse spines; regular and complete bud break in spring; low susceptibility to root rot and cane diseases.

Grandeur. Productive, midseason, primocane-fruiting red raspberry with consistent primocane and floricane production in central coast California and similar climates in Mexico. Origin: Plant Sciences Inc., Watsonville, CA, by S.M. Ackerman and S.W. Adams. PS-737 x PS-1509; selected 2003; USPP pending. Fruit: medium to large; excellent firmness; medium-light red; conic; medium gloss and flavor; releases easily from receptacle; in California ripens mid-July through November on primocanes and May-July on floricanes. Plant: light green primocanes with little to no waxy coating; moderately dense spines; light-brown floricanes; slightly susceptible to yellow rust (Kuehneola uredinis) and powdery mildew (Podosphaera aphanis).

Jeanne d'Orléans. A winter-hardy, large-fruited, very firm, and aromatic red raspberry with excellent shelf life and high antioxidant activity. Origin: Agriculture and Agri-Food Canada, Horticulture Research and Development Centre, Saint Jean sur Richelieu, Quebec, by S. Khanizadeh. Meeker x Chilliwack; crossed 1994; tested as SJR942-7; introd. 2007. Canadian PBRO 06-5438; 2005. Fruit: large; firm; medium red; skin dull and pubescent; long-conic; cylindrical cavity; very flavourful; detaches easily from receptacle without crumbling; strong drupelet cohesion; reported to have much higher ellagic acid content than Boyne, Festival, Killarney, and Nova; ripens $8 \mathrm{~d}$ after Boyne and Killarney. Plant: semi-erect; medium height; floricane laterals longer than Boyne and Killarney; slightly less hardy than Boyne and Killarney.

K81-6. A winter-hardy, floricane-fruiting red raspberry with large fruit for direct marketing. Origin. Agriculture and Agri-Food Canada, Atlantic Food and Horticulture Research Centre, Kentville, Nova Scotia, by D.L. Craig and A.R. Jamieson. O.67-245-01 x BC 64-9-81; crossed 1979; selected 1981. Fruit: large; soft to medium firm; medium red; conic; sweet, flavorful; shelf-life inferior to Nova; late-season, ripens 7-10 d after Nova. Plant: vigorous; moderately spiny canes; resistant to late leaf rust (Pucciniastrum americanum); susceptible to root rot and fire blight (Erwinia amylovora).

Korere. An early, floricane-fruiting red raspberry producing good yields of high quality fruit suited to fresh and processing markets. Origin: Plant and Food Research Limited, Motueka, New Zealand, by M.J. Stephens and H.K. Hall. Moutere x D188; crossed 1991; selected 1994; tested as HR121; introd. 2008. USPP pending. Fruit: medium; moderate firmness; moderate flavor; removes easily from receptacle; suited to hand pick and machine harvesting; early season. Plant: good vigor; spineless upright canes; adapted to low winter chill conditions such as Motueka, New Zealand; resistant to RBDV; susceptible to phytophthora root rot.

Korpiko. A midseason, floricane-fruiting red raspberry producing good yields of high quality fruit suited to fresh markets. Origin: Plant and Food Research Limited, Motueka, New Zealand, by M.J. Stephens and H.K. Hall. Chilcotin x Waimea; crossed 1990; selected 1993; tested as HR6; introd. 2008. USPP pending. Fruit: large; good firmness; good flavor; removes easily from receptacle; suited to hand picking. Plant: strong vigor; semi-spineless; upright canes; adapted to low winter chill conditions such as Motueka, New Zealand; resistant to RBDV.

Radiance. Productive, midseason, primocane fruiting red raspberry with consistent primocane and floricane production in central coast California and similar climates in Mexico. Origin: Plant Sciences 
Inc., Watsonville, CA by S.M. Ackerman and S.W. Adams. PS-1616 x PS-1703; selected in 2001; USPP 20,342; 22 Sept. 2009. Fruit: medium; firm; medium to light red; slightly long-conic; good gloss; excellent flavor; very good shelf life; in California, ripens on primocanes mid-July through November and on floricanes MayJuly. Plant: convex leaves; light green primocanes; little to no waxy coating; moderately dense spines; floricanes reddish-brown; slightly susceptible to yellow rust and powdery mildew.

Rudyberry. A high-yielding, floricane-fruiting red raspberry adapted to the processing and fresh market Origin: Agriculture and AgriFood Canada, Pacific Agri-Food Research Center, Agassiz, BC, Canada, by C. Kempler and H.A. Daubeny. BC 86-41-15 x Qualicum; BC 86-41-15 is a $3^{\text {rd }}$ generation Rubus strigosus derivative selected from a wild population at Dalhousie Lake, Quebec; crossed 1990; selected 1994; tested as BC 90-4-23; introd. 2009. Canadian PBR applied for. Fruit: large; firm; medium to dark red; medium drupelets; conical; excellent appearance; high gloss; machine harvests very well; suited for processing and early fresh market; ripens early. Plant: floricanes are straight, strong, and thinner than those of Tulameen and Chemainus, similar to Saanich and Meeker; long and strong laterals with fruit that is spread on laterals; canes light red-brown with no basal cracking; spines are 3 $\mathrm{mm}$ long, downward pointing, no basal spot; resistant to North American large raspberry aphid (A. agathonica); susceptible to RBDV; some resistance to root rot; moderately susceptible to spur blight, (Didymella applanata), cane botrytis (Botrytis cinerea), and anthracnose (Elsinoe veneta).

Sugana. A high-quality, dual-cropping, fresh-market red raspberry. Origin: Lubera AG, Buchs, Switzerland, by M. Kobelt. Autumn Bliss x Tulameen; selected 1999; USPP applied for. Fruit: large; very bright, non-darkening red; round-conical; shelf-life up to $10 \mathrm{~d}$; ripens early spring; midseason primocane fruiting; primarily cultivated for primocane fruit; moderate removal force required to separate from receptacle; tolerance to rainfall higher than Autumn Bliss; production two weeks later than Autumn Bliss. Plant: vigorous; mature plants have 3-5 canes; 2-3 laterals on primocanes, good field tolerance to phytophthora root rot.

\section{TulaMagic $^{\circledR}$. See Frutafri.}

Ukee. A high-yielding, floricane-fruiting red raspberry adapted to fresh and individual quick frozen markets. Origin: Agriculture and Agri-Food Canada, Pacific Agri-Food Research Center, Agassiz, BC, Canada, by C. Kempler and H.A. Daubeny. Chilliwack x BC 8641-15; BC $86-41-15$ is a $3^{\text {rd }}$ generation Rubus strigosus derivative selected from a wild population at Dalhousie Lake, Quebec; crossed 1992; selected 1996; tested as BC 92-6-41; introd. 2009; Canadian PBR applied for. Fruit: large to medium; medium to light red, low gloss; some dusty appearance; conical with small drupelets; excellent appearance; recommended for fresh market, machine harvesting for processing, and IQF. Plant: floricanes are straight, strong, thinner than Tulameen, Malahat, and Chemainus but similar to Saanich and Meeker; laterals long, strong, carry yield well; canes cinnamon brown with minimal basal cracking; spines cinnamon brown, $2 \mathrm{~mm}$ long, downward pointing with no basal spot; abundant spines on the lower $40 \mathrm{~cm}$, reduced number and length acropetally; primocanes turn brown to the tip; sheds leaves early; resistant to North American large raspberry aphid; susceptible to RBDV; resistant to root rot; moderately susceptible to spur blight, cane botrytis, and anthracnose.

Wakefield. A mid-late-season, floricane-fruiting red raspberry producing high yields of good quality fruit suited to processing markets. Origin: Plant and Food Research Limited, Motueka, New Zealand, by M.J. Stephens and H.K. Hall. Lewis x 86105M57; crossed 1990; selected 1993; tested as HR40; introd. 2008. USPP applied for. Fruit: medium; very good firmness; some resistance to fruit botrytis; good flavor, high soluble solids; removes very easily from receptacle; very suited to machine harvesting; high quality IQF product.
Plant: strong vigor; very high yields; produces fewer canes than Meeker; semi-spineless, upright canes; adapted to low winter chill conditions such as Motueka, New Zealand; suited to the Pacific Northwest U.S.; similar winter hardiness to Meeker; RBDV tolerant; good field resistance to phytophthora root rot and cane botrytis.

\section{STRAWBERRY}

Kim S. Lewers, USDA-ARS, Genetic Improvement of Fruits and Vegetables Laboratory, Beltsville, MD

Amelia. Late-season, short-day strawberry adapted to northern Europe. Origin: East Malling Research, Kent, UK, by D.W. Simpson, J.A. Bell, and K.J. Hammond. Complex pedigree including Pandora, Marmolada, Kent, and Providence; crossed 1997; selected 1998; tested as EM1103; introd. 2007; EU PVR applied for. Fruit: medium red skin; large; conical; uniform; firm; good flavor; ripens June-July, $10 \mathrm{~d}$ after Elsanta. Plant: vigorous; moderate yield; flowers above foliage; moderate runner production; resistant to powdery mildew (Podosphaera aphanis formerly Sphaerotheca macularis) and phytophthora crown rot (Phytophthora cactorum); moderately susceptible to verticillium wilt (Verticillium dahliae).

Amiga. Short-day strawberry adapted to Huelva, Spain. Origin: Instituto Nacional de Investigaciones Agrarias (INIA), the Instituto de Investigación y Formación Agraria y Pesquera (IFAPA) (Málaga and Huelva, Spain), the Instituto Valenciano de Investigaciones Agrarias (IVIA) (Valencia, Spain), and Viveros California, S.L., Seville, Spain, by C. Sorial, J.F. Sánchez-Sevilla, M.T. Ariza, J. Gálvez, J.M. López-Aranda, J.J. Medina, L. Miranda, A. Arjona, and R. Bartual. Camarosa x 3-79; selected 1998; tested as 2-269. EU PVR applied for. Fruit: red skin; uniformly large, $26.3 \mathrm{~g}$, similar to Camarosa; long, wedge-shaped; flesh medium-red; as firm as or firmer than Camarosa; small internal cavity; aromatic flavor; achenes level with surface, large calyx; ripend $3^{\text {rd }}$ week in January to $3^{\text {rd }}$ week in May. Plant: vigorous; high yield, $747 \mathrm{~g} / \mathrm{plant}$, similar to Camarosa; flat globose, medium plant density; long peduncles; susceptibility to powdery mildew and two-spotted spider mite (Tetranychus urticae) similar to Camarosa.

Argentera. Late-season, short-day strawberry adapted to northern Italy. Origin: Italian National Project "Frutticoltura", Cesena, Italy, by M. Baudino and R. Giordano at Consorzio di Ricerca Sperimentazione e Divulgazione per l'Ortofrutticoltura Piemontese-Cuneo, and W. Faedi, G. Baruzzi, and P. Sbrighi at CRA-FRF-Unità di Ricerca per la Frutticoltura-Forli. CN 93.311.1 [CN 90.577.4 (Pandora x Irvine) x Idea] x 91.143.5 (86.288.1 x Cortina); crossed 1998; selected in Cuneo in 2000; tested as CN 98.164.1; introd. 2009; patented in Italy; application file number: NVFO 0001/09; Feb. 2009. Fruit: very light orange-red skin; medium-large; uniform conic; good flavor, very sweet, balanced with acidity; high $\mathrm{C}$ vitamin content; firm; high skin resistance; long shelf-life. Plant: vigorous; very productive; dense; high branch crown number; tolerant to main soil borne pathogens and powdery mildew; low susceptibility to anthracnose (Colletotrichum acutatum) and angular leaf spot (Xanthomonas fragariae).

Cristal. Remontant strawberry adapted to Huelva, Spain. Origin: Plantas De Navarra, S.A. by A. Pierron-Darbonne. 92-61 x 90-45; EU PVR applied for. Fruit: dark red skin; large; almost-cylindrical; glossy, firm red flesh; medium sweetness and acidity; ripens early, first harvest mid-December from mid-October planting. Plant: vigorous; high yield, $1058 \mathrm{~g} /$ plant; globose, medium dense foliage; few stolons; only a few hours chilling required; selected in tunnel production.

Delia. Short-day strawberry adapted to northern Europe. Origin: East Malling Research, Kent, UK, by D.W. Simpson, J.A. Bell, and K.J. Hammond. Honeoye x ISF 80-52-1; crossed 1994; selected 1995; tested as EM835; introd. 2005. Fruit: orange-red skin; large; 
conical; very uniform; very firm; moderate flavor; ripens May-June, one week before Elsanta. Plant: moderate vigor; moderate to high yield; flowers above foliage; good runner production; susceptible to powdery mildew and phytophthora crown rot.

Driscoll Ojai. Partially everbearing strawberry adapted to coastal southern California. Origin: Driscoll Strawberry Associates, Inc., Watsonville, CA, by A. Amorao and M. Ferguson. Driscoll Venice x Driscoll El Capitan; selected 1999; USPP 18,575; 11 Mar. 2008. Fruit: uniform dark red skin; medium, $26.8 \mathrm{~g}$; almost cordate; glossy; firm; flesh orange-red, fine texture; very sweet, moderate acidity; calyx spreading, set level, same diameter as fruit; achenes dark red, level with surface; ripens late January to late May. Plant: vigorous; high yield, $712 \mathrm{~g} /$ plant; open globose habit; moderately resistant to two-spotted spider mite and Strawberry mottle virus (SMV); susceptible to tarnished plant bug (Lygus hesperus) and verticillium wilt; moderately susceptible to botrytis fruit rot (Botrytis cinerea), powdery mildew, and angular leaf spot.

DrisStrawFive. Everbearing strawberry adapted to central coastal California. Origin: Driscoll Strawberry Associates, Inc., Watsonville, CA, by T. Rogers, A.G. Claessens, T.M. Sjulin, and C.D. Fear. Driscoll Jubilee x Driscoll Camarillo; selected 2002, Kent, England; USPP 20,248; 1 Sept. 2009. Fruit: bright red skin; small to medium, $19.4 \mathrm{~g}$; uniform conic; glossy; achenes level with surface; firm; light red flesh; medium to strong sweetness, medium acidity; ripens late April to early November. Plant: vigorous; moderate yield, $518 \mathrm{~g} /$ plant; globose habit; medium density; moderately resistant to moderately susceptible to botrytis fruit rot and verticillium wilt; moderately susceptible to two-spotted spider mite; susceptible to cyclamen mite (Tarsonemus pallidus) and powdery mildew.

DrisStrawFour. Everbearing strawberry adapted to central Florida. Origin: Driscoll Strawberry Associates, Inc., Watsonville, CA, by K.L. Gilford and B.D. Mowrey. 6F364 x Mirador; selected 2000; USPP 19,240; 16 Sept. 2008. Fruit: dark red skin; medium small, $28 \mathrm{~g}$; cordate, as broad as long; bright red flesh; medium firmness; hollow center; very sweet, medium acidity; achenes variable from red to gold and level with surface; ripens early to mid-November to early April. Plant: vigorous; moderate yield, $443 \mathrm{~g} / \mathrm{plant}$; flat globose, medium to dense foliage; resistant to leaf scorch (Diplocarpon earliana), leaf blight (Phomopsis obscurans), black root rot (disease complex), SMV, verticillium wilt, leather rot (Phytophthora cactorum); moderately resistant to cyclamen mite, spring dwarf nematode (Aphelenchoides fragariae), powdery mildew, red stele (Phytophthora fragariae), common leaf spot (Ramularia tulasnei); moderately susceptible to two-spotted spider mite, lesion nematode (Pratylenchus penetrans), aphids (Aphis spp.), tarnished plant bug, botrytis fruit rot, and angular leaf spot.

DrisStrawOne. Short-day strawberry adapted to coastal southern California. Origin: Driscoll Strawberry Associates, Inc., Watsonville, CA, by M. Ferguson, A.Q. Amorao, and B.D. Mowrey. Driscoll El Capitan x Driscoll Agoura; selected 2002; USPP 18,458; 2 Jan. 2008. Fruit: red skin; medium, 29.2 g; conic; medium firm; fine textured orange-red and white flesh; medium hollow center; average sweetness; large reflexed calyx; average gloss; achenes below surface. Plant: vigorous; high yield, 957 g/plant; small; open foliage.

DrisStrawThree. Everbearing strawberry adapted to southern coastal California. Origin: Driscoll Strawberry Associates, Inc., Watsonville, CA, by M.D. Ferguson and B.D. Mowrey. 5F205 x San Juan; selected 2002; USPP 19,673; 3 Feb. 2009. Fruit: red skin; large, $27.5 \mathrm{~g}$; almost cylindrical; light red and white flesh; very fine texture; very sweet with mild acidity; achene color variable, level with surface; midseason. Plant: vigorous; moderate yield, $500 \mathrm{~g} /$ plant; flat globose; medium dense foliage; moderately resistant to drought, heat, wind, high $\mathrm{pH}$, and salt; resistant to powdery mildew; moderately resistant to two-spotted spider mite, cyclamen mite, spring dwarf nematode, lesion nematode, bulb and stem nematode (Ditylenchus dipsac), strawberry blossom weevil (Anthonomus rubi), aphids, and tarnished plant bug; moderately susceptible to botrytis fruit rot.

DrisStrawTwo. Everbearing strawberry for coastal central California. Origin: Driscoll Strawberry Associates, Inc., Watsonville, CA, by B.D. Mowrey, M. Ferguson, J.F. Coss, M.P. Madesko, and A.Q. Amorao. Driscoll Camarillo x Driscoll Marin; selected 2002; USPP 18,878; 3 June 2008. Fruit: red skin; large, 24.7 g; conical; firm, orange-red flesh, solid center; average sweetness; glossy; achenes level with to above surface; midseason. Plant: moderate vigor; extremely high yield, $1,654.7 \mathrm{~g} / \mathrm{plant}$; flat globose; resistant to powdery mildew; moderately resistant to SMV and angular leaf spot; moderately susceptible to botrytis fruit rot; susceptible to twospotted spider mite, tarnished plant bug, and verticillium wilt.

Elegance. Short-day strawberry adapted to northern Europe. Origin: East Malling Research, Kent, UK, by D.W. Simpson, A.B. Whitehouse, A.W. Johnson, and K.J. Hammond. EM 823 x EM 1033; crossed 2000; selected 2001; tested as EM1276; introd. 2009; EU PVR applied for. Fruit: medium red skin; large; conical; firm; moderate flavor; very uniform and glossy; ripens June-July, one week after Elsanta. Plant: vigorous; very high yield; flowers above foliage; good runner production; susceptible to powdery mildew; very well adapted to 60 -day production.

Everest. Day-neutral strawberry primarily adapted to northern Europe. Origin: Edward Vinson Limited, Kent, UK, by P. Vinson and S. Warren. Irvine x Evita; crossed 1992; selected 1993; EU PVR 5650; 20 Dec. 1999. Fruit: uniform red skin; medium to large; predominantly conical; medium red flesh; firm; absent or weakly expressed hollow center; medium sweetness, high acidity; glossy smooth surface; achenes below surface; calyx level with fruit, medium adherence, slightly larger than the fruit; ripens early, June to October. Plant: medium to strong vigor; good yield; flat globose habit; medium to dense foliage; inflorescence level with foliage; easy harvest; runner production poor; does not require chilling for flower induction; poor tolerance to high temperatures; good tolerance to powdery mildew.

Eves Delight. Day-neutral strawberry primarily adapted to northern Europe. Origin: Edward Vinson Limited, Kent, UK, by P. Vinson and S. Warren. 02P78 x 02EVA13R; crossed 2003; selected 2004; EU PVR applied for. Fruit: uniform bright red, glossy skin; large, uniform; primarily wedge-shaped; flesh bright orange-red; slight to moderate hollow center; excellent flavor and texture; good aroma; high sugars, low acid; achenes even to slightly protruded; calyx generally smaller; strong adherence; ripens medium to late, June to October. Plant: medium to strong vigor; moderate yield; erect, upright and open growth habit; inflorescence erect, long, and mostly exposed; runner production good; chilling beneficial for flower induction; resistant to powdery mildew, phytophthora crown rot, and verticillium wilt.

Evie 2. Day-neutral strawberry primarily adapted to northern Europe. Origin: Edward Vinson Limited, Kent, UK, by P. Vinson and S. Warren. Everglade x J92 D12; crossed 1997; selected 1998; EU PVR 14770; 7 Feb. 2005. Fruit: uniform orange-red skin; large; predominantly conical; flesh light red; firm; absent or very weak hollow center; medium sweet, medium acidity; glossy, smooth skin, achenes below surface; calyx level with and same diameter as fruit, medium adherence; ripens early to medium, June to October. Plant: strong vigor; high yield; flat globose habit; open to medium density; inflorescence level with foliage; easy picking; runner production good; does not require chilling for flower induction; some tolerance to high temperatures; good tolerance to verticillium wilt, phytophthora crown rot, and powdery mildew.

Evie 3. Day-neutral strawberry primarily adapted to Northern Europe. Origin: Edward Vinson Limited, Kent, UK, by P. Vinson 
and S. Warren. Everglade x EVA6; crossed 1990; selected 1999; EU PVR 19,752; 2 Apr. 2007. Fruit: orange-red, smooth, glossy skin; medium to large; predominantly conical; flesh orange-red; firm; weakly expressed hollow center; sweet, medium acidity; achenes below surface; calyx level with fruit, strong adherence, same diameter as fruit; ripens early to medium, June to October Plant: medium to strong vigor; high yield, $1000 \mathrm{~g} /$ plant; flat globose habit; open to medium density; inflorescence above foliage; runner production good; does not require chilling for flower induction; poor tolerance to high temperatures; good tolerance to powdery mildew.

Fenella. Shortday strawberry adapted to northern Europe. Origin: East Malling Research, Kent, UK, by D.W. Simpson, A.B. Whitehouse, A.W. Johnson, and K.J. Hammond. Lucy x EM972; crossed 2000; selected 2001; tested as EM1308; introd. 2009. Fruit: medium red skin; large; conical; uniform; firm; good flavor; ripens June-July, one week after Elsanta. Plant: vigorous; high yield; flowers level with foliage; good runner production; resistant to verticillium wilt and phytophthora crown rot; moderately susceptible to powdery mildew; good tolerance to rain.

Finesse. Everbearing strawberry adapted to northern Europe. Origin: East Malling Research, Kent, UK, by D.W. Simpson, A.B. Whitehouse, A.W. Johnson, and K.J. Hammond. EM1117 x Everest; crossed 2002; selected 2003; tested as EMR346; introd. 2010. Fruit: medium red skin; large; conical; uniform; firm; good flavor; ripens July to October. Plant: moderate vigor; high yield; flowers level with foliage; shy runner production; resistant to verticillium wilt and phytophthora crown rot; moderately resistant to powdery mildew.

Florida Elyana. Short-day strawberry for protected cultivation in winter and spring. Origin: University of Florida, by C.K. Chandler. FL 96-114 x FL 95-200; crossed 2000; USPP applied for. Fruit: bright red skin; large, 24-27 g; conic to wedge-shaped, and wedgeshaped fruit often is creased; firm, carmine-pink flesh; sweeter than Strawberry Festival, pleasant aromatic flavor; ripens January-March. Plant: moderate to low vigor; high yield, 626-715 g/plant; small, low stature, long pedicels; could be planted in high density for greater yield per tunnel unit; moderately resistant to botrytis fruit rot, anthracnose fruit rot, and crown rots ( $C$. gloeosporioides and Phytophthora spp.); susceptible to surface cracking with rain.

Florida Radiance. Short-day strawberry adapted to winter production in Florida. Origin: University of Florida, by C.K. Chandler. Winter Dawn x FL 99-35; crossed 2001; selected 2001; tested as FL 01-116; USPP 20,363; 29 Sept. 2009. Fruit: bright to dark red skin; medium, 21-23 g; conic with early fruit elongated and primaries asymmetrical; firm, orange-red flesh; juicy; acceptable flavor; glossy, achenes slightly sunken; ripens December to March. Plant: high yield, 847-1,047 g/plant; more open habit than Strawberry Festival; long pedicels; moderately resistant to botrytis fruit rot and anthracnose fruit rot; susceptible to crown rots (most likely caused by C. gloeosporioides and Phytophthora spp.).

Galletta. Short-day strawberry adapted to North Carolina. Origin: North Carolina State University, by J.R. Ballington. NCH 87-22 x Earliglow; selected 1993; tested as NCS 93-05; USPP 19,763; 24 Feb. 2009. Fruit: dark purple-red and red blend skin; as large as Camarosa, $32 \mathrm{~g}$ primaries, $20 \mathrm{~g}$ secondaries, $10 \mathrm{~g}$ tertiaries; long conic to conic; orange-red flesh, firmer and tougher than Bish and Chandler, less firm and tough than Camarosa; achenes slightly below surface; ripens very early, first ripe fruit 7 Apr., before Bish, Camarosa, and Chandler. Plant: medium vigor; yields greater than or equal to Chandler and Camarosa; medium canopy density; crown and fruit resistant to anthracnose, but fruit susceptible when artificially inoculated with $C$. acutatum. Named in memory of long-time North Carolina State University and USDA-ARS strawberry breeder Gene J. Galletta.

Judibell. Very late, short-day strawberry adapted to northern Europe. Origin: East Malling Research, Kent, UK, by D.W.
Simpson, J.A. Bell, and K.J. Hammond. Complex pedigree including Pandora and Elsanta; crossed 1995; selected 1996; tested as EM965; introd. 2005; EU PVR 21,937. Fruit: pale to medium red skin; medium large; conical; uniform; medium firm; moderate flavor; very late, ripens July, 5 weeks after Elsanta. Plant: vigorous; moderate yield; dense habit; flowers below foliage; good runner production; resistant to verticillium wilt, phytophthora crown rot, and anthracnose fruit rot; moderately resistant to powdery mildew; suitable for pick-your-own and direct sales.

Lucy. Shortday strawberry adapted to northern Europe. Origin: East Malling Research, Kent, UK, by D.W. Simpson, J.A. Bell, and K.J. Hammond. Complex pedigree including Honeoye, Selva, and Rapella; crossed 1995; selected 1996; tested as EM931; introd. 2009; EU PVR applied for. Fruit: medium red skin; very large; irregular primary berries, then uniform; conical; firm; moderate flavor; ripens June-July, one week after Elsanta. Plant: vigorous; very high yield; flowers level with foliage; fair runner production; resistant to phytophthora crown rot; moderately susceptible to powdery mildew and verticillium wilt; good tolerance to rain.

Mae. Shortday strawberry adapted to northern Europe. Origin: East Malling Research, Kent, UK, by D.W. Simpson, J.A. Bell, and K.J. Hammond. Rosie x Onebor; crossed 1994; selected 1995; tested as EM884; introd. 2003; EU PVR 16,919. Fruit: deep red; large; conical; uniform; firm; moderate flavor; ripens May-June, one week before Elsanta. Plant: moderate vigor; high yield; flowers above foliage; good runner production; susceptible to powdery mildew and phytophthora crown rot.

Malling Opal. Everbearing strawberry adapted to northern Europe. Origin: East Malling Research, Kent, UK, by D.W. Simpson, J.A. Bell, and K.J. Hammond. Complex pedigree including Evita, Selva, Elsanta, Providence, and Etna; crossed 2000; selected 2001; tested as EMR287; introd. 2005; EU PVR 21,939. Fruit: deep red skin; very large; conical, irregular primary berries then uniform; medium firm; excellent flavor; ripens July to October. Plant: vigorous; very high yield; flowers level with foliage, good runner production; moderately resistant to powdery mildew; susceptible to phytophthora crown rot.

Malling Pearl. Everbearing strawberry adapted to northern Europe. Origin: East Malling Research, Kent, UK, by D.W. Simpson, J.A. Bell, and K.J. Hammond. Complex pedigree including Evita, Selva, Elsanta, Providence, and Etna; crossed 2000; selected 2001; tested as EMR286; introd. 2005; EU PVR 21938. Fruit: mid-red, strong skin; large; blunt conical; uniform; moderately firm flesh; excellent flavor; ripens July to October. Plant: vigorous; high yield; flowers level with foliage, good runner production; moderately resistant to powdery mildew; susceptible to phytophthora crown rot.

Monterey. Day-neutral strawberry adapted to coastal central and southern California. Origin: University of California, Davis, by D.V. Shaw and K.D. Larson. Albion x Cal 97.85-6; crossed 2001; selected 2002; tested as Cal 1.132-3 and CN222; USPP 19,767; 24 Feb. 2009. Fruit: skin similar to Aromas and Albion, darker than Diamante; very large, $32.4 \mathrm{~g}$; symmetrical or slightly flattened conic; flesh more red than Aromas and Albion; solid or with small hollow center; as firm as Albion and Diamante; good flavor with sweet aftertaste; achenes even with or slightly below fruit surface, variable color from yellow to dark red; ripens early April through early October. Plant: vigorous; extremely high yield, 3,301 g/plant; large, open, erect; moderately resistant to anthracnose crown rot and verticillium wilt; moderately susceptible to powdery mildew, phytophthora crown rot, and common leaf spot; tolerant to strawberry viruses encountered in California; conditional tolerance to twospotted spider mite.

Nisgaa. Short-day strawberry adapted to the Pacific Northwest for the fresh and processing market. Origin: Agriculture and Agri-Food 
Canada, Pacific Agri-Food Research Centre, Agassiz, B.C., Canada, by C. Kempler and H.A. Daubeny. Cavendish x Nanaimo; crossed 1992; selected 1996; tested as BC92-20-85; introd. 2009. Canadian PBR applied for. Fruit: medium-dark glossy red skin; larger than Totem; mostly wedge-shaped; pleasant sweet northern strawberry flavor; attractive calyx that is readily removable; yellow-green achenes are slightly above surface; ripens 3-5 d before Totem. Plant: moderately vigorous; very productive in matted rows; smaller than Puget Reliance; large root:shoot ratio; abundant runners produced; winter hardy in the Pacific Northwest; tolerant of powdery mildew, strawberry aphid (Chaetosiphon fragaefoli)-transmitted strawberry virus complex, and some soil borne diseases.

Palomar. Short-day strawberry adapted to coastal central and southern California. Origin: University of California, Davis, by D.V. Shaw and K.D. Larson. Camino Real x Ventana, direction unknown; crossed 2000; selected 2001; tested as Cal 0.259-2 and C221; USPP 19,472; 25 Nov. 2008. Fruit: skin similar color to Ventana; very large, $30.2 \mathrm{~g}$; short conic; flesh similar in color to Ventana; calyx weakly attached; achenes yellow to dark red and even with fruit surface; season similar to Camarosa and Camino Real. Plant: vigor similar to Camino Real; extremely high yield, 2,031 g/ plant; small, similar in size to Camino Real, more compact than Ventana; moderately resistant to powdery mildew, anthracnose crown rot, and verticillium wilt; moderately susceptible to phytophthora crown rot and common leaf spot; tolerant to strawberry viruses encountered in California; conditional tolerance to two-spotted spider mite; responds well to early winter planting.

Premier. Everbearing strawberry adapted to coastal central California and broadly to northern European climates. Origin: Plant Sciences, Inc., Watsonville, CA, by S.M. Ackerman, S.D. Nelson, and M.D. Nelson. PS-1269 x PS-3003; crossed 2001; selected 2003. USPP 20,309; 15 Sept. 2009. Fruit: medium red; medium to large, $24.7 \mathrm{~g}$; conic to ovate; medium red flesh; firm; yellow to red achenes level with fruit surface; spreading calyx, glossy; ripens in central California September through December, ripens in northern Europe mid-June through September; good flavor. Plant: vigorous; moderate to low yield, $381 \mathrm{~g} /$ plant; medium; short pedicels; moderately susceptible to two-spotted spider mite, thrips (Frankliniella occidentalis), botrytis fruit rot, and angular leaf spot; susceptible to powdery mildew and tarnished plant bug.

Sallybright. Short-day strawberry adapted to northern Europe. Origin: East Malling Research, Kent, UK, by D.W. Simpson, A.B. Whitehouse, A.W. Johnson, and K.J. Hammond. Complex pedigree including Alice, Selva, and Eros; crossed 2002; selected 2003; tested as EM1296; introd. 2007. Fruit: deep red skin; large; conical; very uniform; medium firm; good flavor; ripens June, $5 \mathrm{~d}$ before Elsanta. Plant: moderate vigor; moderate yield; erect habit, flowers above foliage; good runner production.

San Andreas. Day-neutral strawberry adapted to coastal central and southern California. Origin: University of California, Davis, by D.V. Shaw and K.D. Larson. Albion x Cal 97.86-1; crossed 2001; selected 2002, tested as Cal 1.139-2 and CN223; USPP 19,975; 12 May 2009. Fruit: red skin, slightly lighter than Albion and Aromas, darker than Diamante; large, $31.6 \mathrm{~g}$; medium-long symmetrical conic; firmness and flavor similar to Albion; flesh darker and more red than Albion; medium-size hollow core; achenes mostly red with some yellow, even with to slightly below skin surface; season and production pattern similar to Albion, though better suited to earlyseason winter planting. Plant: more vigorous than Albion, Aromas, and Diamante; extremely high yield, 3,293 g/plant; similar in appearance to Albion and Diamante, smaller and more compact than Aromas; moderately resistant to powdery mildew, anthracnose crown rot, verticillium wilt, phytophthora crown rot, and common leaf spot; tolerant to two-spotted spider mite and strawberry viruses encountered in California.
Sasha. Short-day strawberry adapted to glasshouse production in northern Europe. Origin: East Malling Research, Kent, UK, by D.W. Simpson, J.A. Bell, and K.J. Hammond. EM881 x Eros; crossed 1998; selected 1999; tested as EM1159; introd. 2008. Fruit: medium red skin; large; conical; very uniform; firm; moderate flavor; ripens November and April/May in glasshouse. Plant: vigorous; very high yield; erect habit, flowers above foliage; good runner production; susceptible to powdery mildew.

Sonata. Short-day strawberry adapted to The Netherlands. Origin: Plant Research International B.V., Wageningen, The Netherlands, by E.J. Meulenbroek. Elsanta x Polka; crossed 1990; selected 1992; USPP 18,000; 11 Sept. 2007. Fruit: glossy, light orange-red skin; 4$5 \mathrm{~cm}$ long, 5-6 cm wide; uniform round conic; light orange-red flesh; small or absent hollow; pleasant aroma and taste; light orange-red achenes level with surface; ripens early. Plant: moderate vigor; high yield; compact flattened globose, upright, open, multiple crowns.

Sweet Eve. Day-neutral strawberry primarily adapted to Northern Europe. Origin: Edward Vinson Limited, Kent, UK, by P. Vinson and S. Warren. 01BB64 x S01R5; crossed 2003; selected 2004; EU PVR applied for. Fruit: very uniform bright orange-red, glossy skin; uniform medium to large; primarily long conical, slight neck; bright orange-red flesh; excellent firmness; excellent flavor, strong refreshing aroma; high soluble solids, low acidity; absent or weakly expressed hollow center; achenes even to slightly below surface; calyx smaller than the fruit, typically reflexed, medium adherence; ripens medium to early June to October. Plant: medium vigor; high yields; upright and dense growth habit; inflorescence level to slightly exposed; cupped leaflets; good runner production; requires no chilling for flower induction; some tolerance to high temperatures and powdery mildew; susceptible to phytophthora crown rot and verticillium wilt.

Tecla. Short-day strawberry adapted to northern Italy. Origin: Italian National Project "Frutticoltura," mainly financed by the Ministry of Agriculture, and "Top Quality Project" funded by Emilia-Romagna Region Authority (through CRPV), Cesena, Italy, by W. Faedi, G. Baruzzi, and P. Sbrighi at CRA-FRF - Unità di Ricerca per la Frutticoltura-Forli, and P. Lucchi at Centro Ricerche Produzioni Vegetali-Cesena. 93.608.12 x Onda; crossed 2000; selected 2002 in Cesena; tested as 00.92.4; introd. 2009. EU PVR applied for. Fruit: bright red skin; larger than Onda; symmetric long conic; firm; medium skin resistance; high sugar content, well balanced with acidity, good flavor; medium ascorbic acid content; long shelf-life; ripens midseason. Plant: very vigorous; very productive particularly under protected culture; higher yield than Onda; prostrate; high branch crown number; tolerant to main soil borne pathogens; low susceptibility to powdery mildew; medium susceptibility to anthracnose and angular leaf spot.

Treasure Harvest. Short-day strawberry adapted to southern Florida winter production. Origin: P.P. Chang. Treasure x A4; selected 2002; USPP 19,422; 4 Nov. 2008. Fruit: red skin; larger than fruit of Treasure, 44-55 mm long, 36-50 mm diameter; oblong; longer shelf-life and firmer than fruit of Treasure; SS 9.9\%; ripens December to mid-March Plant: very vigorous; high yield, $744.5 \mathrm{~g}$ / plant; globose; moderately resistant to anthracnose fruit rot (screened with C. acutatum, C. fragariae, and C. gloeosporioides).

Unica. Short-day strawberry adapted to northern Italy. Origin: Italian National Project "Frutticoltura," mainly financed by the Ministry of Agriculture, and "Top Quality Project," funded by Emilia-Romagna Region Authority (through CRPV), Cesena, Italy, by W. Faedi, G. Baruzzi, and P. Sbrighi at CRA-FRF- Unità di Ricerca per la Frutticoltura-Forli, and P. Lucchi at Centro Ricerche Produzioni Vegetali-Cesena. Miss x 91.143.5; crossed 1997; selected 1999 in Cesena; tested as 97.129.11; introd. 2009. Italy PVR applied for Fruit: red skin, stable during cold storage after picking, but quite dark in hot harvest period; very large; symmetric long 
conic; firm; low sugar content, slightly aromatic; ripens midseason. Plant: vigorous; very productive; erect, medium crown number; tolerant to main soil borne pathogens; low susceptibility to anthracnose and angular leaf spot; susceptible to powdery mildew.

Vale. An early season, short-day cultivar adapted to Northern Italy. Not related to USDA-ARS, Oregon release in 1950 with the same name. Origin: Italian National Project "Frutticoltura" mainly financed by the Ministry of Agriculture, and "Top Quality Project," funded by Emilia-Romagna Region Authority (through CRPV), Cesena, Italy, by W. Faedi, G. Baruzzi, and P. Sbrighi at CRAFRF-Unità di Ricerca per la Frutticoltura-Forli, and P. Lucchi at Centro Ricerche Produzioni Vegetali-Cesena. 90.316.1 x 92.435.1; crossed 1996; selected 1998 in Cesena; tested as 96.46.2; introd. 2009. Italy PVR applied for. Fruit: bright orange-red, very firm skin; large; long conic; firm flesh; high sugar content well balanced with acidity, faintly aromatic; high ascorbic acid content. Plant: medium vigor; average yield; medium susceptibility to main soilborne pathogens and powdery mildew; susceptible to anthracnose and angular leaf spot; needs an early planting date for high yield on fumigated fertile soils.

Valley Red. Short-day strawberry primarily suited to processing and adapted to the Pacific Northwest, US. Origin: USDA-ARS, Corvallis, OR, by C.E. Finn, P.P. Moore, C. Kempler, B.M. Yorgey, B.C. Strik, and R.R. Martin. Anaheim x Puget Reliance; crossed 1994; selected 1996; tested as ORUS 1790-1; introd. 2009. Fruit: dark red skin; uniformly medium, similar to or larger than Totem; uniform conic; smooth uniform surface, medium gloss; flesh deep red; good firmness, similar to or better than Totem; medium soluble solids, comparable to Tillamook; $\mathrm{pH}$ acceptable, similar to Totem; flavor good; caps very easily; excellent overall processing quality; ripens early midseason with Puget Reliance and slightly before Totem and Tillamook. Plant: more vigorous than Totem; high yield similar to Puget Reliance but less than Tillamook; compact architecture not as open as Tillamook; durable in the field with virus pressure; moderately tolerant of botrytis fruit rot, powdery mildew, common leaf spot, and leaf scorch.

Valor. Everbearing strawberry adapted to the coastal central California and broadly to northern European climates. Origin: Plant Sciences, Inc., Watsonville, CA, by S.M. Ackerman, S.D. Nelson, and M.D. Nelson. PS-1269 x PS-3003; crossed 2001; selected 2003; USPP 20,394; 6 Oct. 2009. Fruit: red to dark red glossy skin; medium to large, $23.3 \mathrm{~g}$; conic; red, firm flesh; good flavor; SS 8\%; very good storage quality; achenes level with or below surface; ripens in central California September through December, and in northern Europe mid-June through September. Plant: vigorous; moderate yield, $566 \mathrm{~g} /$ plant; globose, medium; moderately susceptible to two-spotted spider mite, thrips, botrytis fruit rot, and angular leaf spot; susceptible to powdery mildew and tarnished plant bug.

Viva Patricia. Short-day strawberry primarily adapted to southern Spain. Origin: Edward Vinson Limited, Kent, UK, by P. Vinson and S. Warren. S03AC11 x S02AG4; crossed 2004; selected 2005; EU PVR applied for. Fruit: uniform, tough, glossy bright red skin; large; primarily conical with occasional wedge shapes; bright orange-red flesh; moderate firmness; moderate aroma; high soluble solids, low acidity, pleasant eating experience; slight to moderately expressed hollow center; achenes slightly indented; calyx strongly adhering, slightly smaller diameter than the fruit; ripens midseason. Plant: vigorous; high yields; medium to large, dense foliage; inflorescence mostly even and some exposed; very strong anthocyanin coloration of stipules; runner production good; minimal chilling required; susceptible to phytophthora crown rot.

Zeta. Short-day strawberry adapted to northern Italy. Origin: Italian National Project "Frutticoltura," mainly financed by the Ministry of Agriculture, and "Top Quality Project," funded by Emilia-Romagna Region Authority (through CRPV), Cesena, Italy, by W. Faedi, G.
Baruzzi, and P. Sbrighi at CRA-FRF-Unità di Ricerca per la Frutticoltura-Forli, and P. Lucchi at Centro Ricerche Produzioni Vegetali-Cesena. 93,64,9 x 89.384.20; crossed 1998, selected 2000 in Cesena; tested as 98.78.7; introd. 2009. Italy PVR applied for. Fruit: very light red; color stable in cold storage; large; very uniform conic; medium-low taste; early-season. Plant: very vigorous; very productive; erect; high branch crowns number; high pollen fertility; tolerant to abiotic stress, main soilborne pathogens, and powdery mildew; medium susceptibility to anthracnose and angular leaf spot; can be grown in non-fumigated soils and organic production systems.

\section{INDEX}

8909-05 GRAPE ROOTSTOCK

9363-16 GRAPE ROOTSTOCK

9365-43 GRAPE ROOTSTOCK

9365-85 GRAPE ROOTSTOCK

9407-14 GRAPE ROOTSTOCK

A-2640 GRAPE

A268 MACADAMIA

AB17 APPLE

AC1 APRICOT

Adele RASPBERRY

African shaddock x Rubidoux trifoliate CITRUS ROOTSTOCK

Ajubá PINEAPPLE

Alba BLUEBERRY

Alice-col NECTARINE

Alitop NECTARINE

Allspice CITRUS (TANGELO)

Altair BLUEBERRY

Alvina APPLE

Amatsubu-Boshi (Sweet Star) BLUEBERRY

Ambrosia POMEGRANATE

Amelia STRAWBERRY

Amiga STRAWBERRY

Amigo I PLUM-INTERSPECIFIC

Añasco GENIP

Andes Du-1 PEACH

Angie MANGO

Apalachee PECAN

APF-45 BLACKBERRY

Apriplum III PLUM-INTERSPECIFIC

Apriplum VII PLUM-INTERSPECIFIC

ARC NE-1 NECTARINE

ARC NE-2 NECTARINE

ARC NE-8 NECTARINE

Argentera STRAWBERRY

Arkangel PEACH

Armoore PEACH

August Lion III NECTARINE

Aus-Carnival PINEAPPLE

Aus-Jubilee PINEAPPLE

Autumn Bright NECTARINE

Autumn Crunch PEACH

Autumn Gold Late Navel CITRUS (ORANGE)

Autumn Sprite PUBESCENT PRUNOPHORA HYBRID

Autumn Treasure RASPBERRY

Awaroa RASPBERRY

Azulema BLUEBERRY

B. Thome McIntosh APPLE

B74 MANGO

Banning Red Fuji APPLE

Barnfield Late Navel CITRUS (ORANGE)

BE4 CRANBERRY

Bella Cerise PUBESCENT PRUNOPHORA HYBRID

Bella Gold PUBESCENT PRUNOPHORA HYBRID

Bella Royale PUBESCENT PRUNOPHORA HYBRID

Beller APPLE

Bethan RASPBERRY

Bitters trifoliate hybrid CITRUS ROOTSTOCK 
Black Beauty PASSION FRUIT

Black Knight PASSION FRUIT

Black Majesty PLUM-JAPANESE

Blackred I PLUM-INTERSPECIFIC

Blackred II PLUM-INTERSPECIFIC

Blackred III PLUM-INTERSPECIFIC

Blackred V PLUM-INTERSPECIFIC

Blue Suede ${ }^{T M}$ BLUEBERRY

Bolaroja APRICOT

Brak APPLE

Brazilian Gold PASSION FRUIT

BRS Âmbar PEACH

BRS Kampai PEACH

BRS Libra PEACH

Burkitt Gala APPLE

Burnectwentytwo NECTARINE

Byrd PECAN

CABp Fuji APPLE

Calypso ${ }^{\mathrm{TM}}$ MANGO

Candy APPLE

Candysweet V NECTARINE

Candysweet X NECTARINE

Carmen BLUEBERRY

Carpenter trifoliate hybrid CITRUS ROOTSTOCK

Cascade NECTARINE

Cascade PEACH

Cederberg PEACH

Celeste BLUEBERRY

Centra Blue BLUEBERRY

Chisago GRAPE

Chislett Summer Navel ORANGE

CIVG198 APPLE

CJ07 APPLE

Clemenules ORANGE

Cloud POMEGRANATE

CNJ97-105-4 CRANBERRY

Cocktail CITRUS (GRAPEFRUIT/PUMMELO HYBRID)

Colorburst $^{\mathrm{TM}}$ NECTARINE

Concettina NECTARINE

Co-op 31 APPLE

Coparose PLUM-INTERSPECIFIC

Coral-cot PUBESCENT PRUNOPHORA HYBRID

Corona BLUEBERRY

Corona Foothills CITRUS (LEMON)

Cot-N-Candy PUBESCENT PRUNOPHORA HYBRID

Crab POMEGRANATE

Cranberry POMEGRANATE

Crimson Pointe ${ }^{T M}$ PLUM-ORNAMENTAL

Crimson Queen ${ }^{\circledR}$ CRANBERRY

Crimson Royale PLUM-INTERSPECIFIC

Cripoizam PLUM-ORNAMENTAL

Crispdelice Sun PEACH

Crispregal PEACH

Cristal STRAWBERRY

Daddow MACADAMIA

Daisy CITRUS (ORANGE)

DaisySL CITRUS (ORANGE)

Dalinip APPLE

Dalirail APPLE

Dapple Jack PLUM-INTERSPECIFIC

Delia STRAWBERRY

Delicious GRAPE

Del Monte Gold ${ }^{\mathrm{TM}}$ PINEAPPLE

Demoranville ${ }^{\circledR}$ CRANBERRY

Dewey POMEGRANATE

Diva APPLE

Diva $^{\circledR}$ APPLE

Diwa $^{\circledR}$ APPLE

Dolores BLUEBERRY

Dominican Red PLANTAIN

Donutnice NECTARINE
Driscoll Ojai STRAWBERRY

DrisStrawFive STRAWBERRY

DrisStrawFour STRAWBERRY

DrisStrawOne STRAWBERRY

DrisStrawThree STRAWBERRY

DrisStrawTwo STRAWBERRY

Dudek APPLE

Earligold PEACH

Early Glo NECTARINE

Early Gold CITRUS (ORANGE)

Edgehill PASSION FRUIT

El Niño APPLE

Elegance STRAWBERRY

Emmons APPLE

Envy $^{\text {TM }}$ APPLE

Eppich 2 APPLE

Escort PUBESCENT PRUNOPHORA HYBRID

Española Roja PINEAPPLE

Eudora GRAPE

Eureka SL ${ }^{\circledR}$ CITRUS (LEMON)

Eve POMEGRANATE

Everest STRAWBERRY

Eves Delight STRAWBERRY

Evie 2 STRAWBERRY

Evie 3 STRAWBERRY

Farthing BLUEBERRY

Fenella STRAWBERRY

FHIA 17 BANANA

FHIA 18 BANANA

FHIA 2 BANANA

FHIA 21 PLANTAIN

Finesse STRAWBERRY

Fisher CITRUS (ORANGE)

Flatprincesse PEACH

FLHORAN41 PINEAPPLE

Florida Elyana STRAWBERRY

Florida Radiance STRAWBERRY

Fraser Seville CITRUS ROOTSTOCK

Furr trifoliate hybrid CITRUS ROOTSTOCK

Frederick PASSION FRUIT

Frostbite APPLE

Frosty PASSION FRUIT

Frutafri RASPBERRY

Fugachee APPLE

Fugachee Fuji APPLE

Fuji Fubrax APPLE

Fujiko APPLE

Fukumoto CITRUS (ORANGE)

GA 10F APRICOT

Galaval APPLE

Galletta STRAWBERRY

Gitit PITANGA

Gold Chief ${ }^{\circledR}$ APPLE

Gold Nugget CITRUS (ORANGE)

Gold Pink APPLE

Golden Giant PASSION FRUIT

Golden Hills PISTACHIO

Goldenmay APRICOT

GP10 PEACH

GP45-11 PEACH

Grand Nain BANANA

Grandeur RASPBERRY

Greenpac PEACH/PLUM ROOTSTOCK

Grygleski \#1 CRANBERRY

Grygleski \#2 CRANBERRY

Grygleski \#3 CRANBERRY

GUN-300 APPLE

Gypzee PLUM-INTERSPECIFIC

HAES 814 MACADAMIA

HAES 816 MACADAMIA

HAES 842 MACADAMIA 
HAES 849 MACADAMIA

Hayabaya-Boshi (Early Star) BLUEBERRY

Hidden Valley A16 MACADAMIA

Hidden Valley A38 MACADAMIA

Hidden Valley A4 MACADAMIA

Honey Gold PINEAPPLE

Honey May NECTARINE

Honey Punch PLUM-INTERSPECIFIC

Honey Red PLUM-JAPANESE

Hortblue Petite BLUEBERRY

Hortblue Poppins BLUEBERRY

HyRed CRANBERRY

IFG 104-253 GRAPE

IFG 31-077 GRAPE

Imperial PINEAPPLE

INTA Delta I PECAN

INTA Delta II PECAN

Itaborai CITRUS (ORANGE)

Jean Ellen MANGO

Jeanne d'Orléans RASPBERRY

Jinok GRAPE

Josapine PINEAPPLE

JR 7827 PEACH

Judibell STRAWBERRY

Julienice. PEACH

July Bright NECTARINE

Junami ${ }^{\circledR}$ APPLE

June Bright NECTARINE

June Sweet NECTARINE

K81-6 RASPBERRY

Kahuna PASSION FRUIT

Kalehghouchi PISTACHIO

Kashmir Blend ${ }^{\text {TM }}$ POMEGRANATE

Kay Diamond V NECTARINE

Kay Diamond VII NECTARINE

$\mathrm{Kiku}^{\circledR}$ APPLE

Kiyomi CITRUS (TANGOR)

Korere RASPBERRY

Korpiko RASPBERRY

La Flamboyante APPLE

Lady in Red APPLE

Lady Laura APPLE

Lane Late CITRUS (ORANGE)

Late Brittney PUBESCENT PRUNOPHORA HYBRID

LB8-9 CITRUS (MANDARIN/TANGELO HYBRID)

Limoneira 8A Lisbon CITRUS (LEMON)

Limoneira Seedless CITRUS (LEMON)

Limonero Fino 49 CITRUS (LEMON)

Lorver PITANGA

Lost Hills PISTACHIO

Lucero BLUEBERRY

Lucia BLUEBERRY

Lucy STRAWBERRY

Mae POMEGRANATE

Mae STRAWBERRY

Magna BLUEBERRY

Mahana Red Braeburn APPLE

Maiden PLANTAIN

Mairac ${ }^{\circledR}$ APPLE

Majestic Pearl NECTARINE

Majestic Sweet NECTARINE

Majesty GRAPE

Malling Opal STRAWBERRY

Malling Pearl STRAWBERRY

Mandan PECAN

Mandared CITRUS (TANGOR)

Manzana PINEAPPLE

Masonova APPLE

May Princess PEACH

MC5 APRICOT

McLaughlin Gala APPLE
MD-2 PINEAPPLE

Melogold CITRUS (GRAPEFRUIT/PUMMELO HYBRID)

Mihong PEACH

Milwa APPLE

Minneiska APPLE

Modi ${ }^{\circledR}$ APPLE

Monterey STRAWBERRY

Moscato Blanco PEACH

Moscato Delicia PEACH

Moscato Tardio PEACH

Mullica Queen ${ }^{\circledR}$ CRANBERRY

Myrto APPLE

Nadia PLUM-INTERSPECIFIC

Nancy Garrison PASSION FRUIT

Nectarexquise NECTARINE

Nectarjewel NECTARINE

Nectracrisp NECTARINE

Nectrajune NECTARINE

Neptune I PEACH

Neptune V PEACH

Newberry BLACKBERRY

Nisgaa STRAWBERRY

NJ350 PEACH

NJ351 PEACH

NJA150 APRICOT

NJF15 PEACH

NJF16 PEACH

NJF17 PEACH

NJF18 PEACH

NJS98-23 CRANBERRY

NJS98-35 CRANBERRY

Nordmann Seedless CITRUS (KUMQUAT)

Norfolk PASSION FRUIT

Ohtsubu-Boshi (Large Star) BLUEBERRY

Orion APPLE

Own Venture MACADAMIA

P.F. 8 Ball PEACH

P.F. Big George PEACH

P.F. Early 8 Ball PEACH

Palomar STRAWBERRY

Parfianka POMEGRANATE

Pavia Sauce PEACH

PB-148 APPLE

Pearl Princess V PEACH

Pearlicious III NECTARINE

Pearlicious V NECTARINE

Pehrson Valencia \#3 CITRUS (ORANGE)

Pehrson Valencia \#4 CITRUS (ORANGE)

Pérola PINEAPPLE

Perolera PINEAPPLE

PETE I PISTACHIO

PG1 PISTACHIO

Phimsen Man MANGO

Pink Champagne BLUEBERRY

Pink Ice POMEGRANATE

Pink Lemonade BLUEBERRY

Pink Ring PEACH

Pink Satin ${ }^{\text {TM }}$ POMEGRANATE

Plumgiant I PLUM-JAPANESE

Plumred I PLUM-INTERSPECIFIC

Plumred X PLUM-INTERSPECIFIC

Plumsweet IX PLUM-INTERSPECIFIC

Plumsweet VI PLUM-INTERSPECIFIC

Plumsweet VII PLUM-INTERSPECIFIC

Plumsweet VIII PLUM-INTERSPECIFIC

Plumsweet X PLUM-INTERSPECIFIC

Plumsweet XI PLUM-INTERSPECIFIC

Plumsweet XII PLUM-INTERSPECIFIC

Plumsweet XIII PLUM-INTERSPECIFIC

Possum Purple PASSION FRUIT

PremA280 APPLE 
Premier STRAWBERRY

Primadonna BLUEBERRY

Primarosa APRICOT

Prime-Ark $^{\circledR} 45$ BLACKBERRY

Prince BLUEBERRY

Princess Time PEACH

Purple Giant PASSION FRUIT

PV 1027 APPLE

Queen Garnet PLUM-JAPANESE

Queen PINEAPPLE

Radiance RASPBERRY

Randy PISTACHIO

Red Riviera PASSION FRUIT

Red Rover PASSION FRUIT

Red Silk ${ }^{\mathrm{TM}}$ POMEGRANATE

Red Topaz APPLE

Red Yummy ${ }^{\circledR}$ PLUM-JAPANESE

Redfield ${ }^{\circledR}$ APPLE

REDYUMMMY.RTM PLUM-JAPANESE

Robert Livermore PERSIAN WALNUT

Rohde Summer Navel CITRUS (ORANGE)

ROHO 3615 APPLE

Rose Princess PEACH

Royal Ruby NECTARINE

RS103-130 APPLE

Ruby Kat PLUM-INTERSPECIFIC

Ruby CITRUS (ORANGE)

Ruby Pink APPLE

Rudyberry RASPBERRY

Ruehle PISTACHIO

RX1 PERSIAN WALNUT ROOTSTOCK

Sallybright STRAWBERRY

San Andreas STRAWBERRY

San Joaquin BLUEBERRY

Sasa GENIP

Sasha STRAWBERRY

Scarlet PEACH

Scilate APPLE

Scintilla BLUEBERRY

Selangor Green PINEAPPLE

Seohong APPLE

Sevilla BLUEBERRY

Shasta Gold ${ }^{\circledR}$ CITRUS (ORANGE)

Shelly MANGO

Shiranui CITRUS (ORANGE)

Singapore Spanish PINEAPPLE

Sin Pepe POMEGRANATE

Sirius APPLE

Smith Red CITRUS (ORANGE)

Snow Angel PEACH

Snow Pearl NECTARINE

Snowchaser BLUEBERRY

Sonata STRAWBERRY

Soomee PEACH

Sotomayor GENIP

Souk GRAPE

Sour POMEGRANATE

Southern Jewel GRAPE

St. Cloud BLUEBERRY

Sugana RASPBERRY

Sugar Belle ${ }^{\text {TM }}$ CITRUS (MANDARIN/TANGELO HYBRID)

Sugarpeach III PEACH

Sugarred I NECTARINE

Sugarred II NECTARINE

Sugarred III NECTARINE

Sugrathirtyfive GRAPE

Sugrathirtyfour GRAPE

Sugrathirtyone GRAPE

Sugrathirtythree GRAPE

Sugrathirtytwo GRAPE

Suhong NECTARINE
Summer Lion IV NECTARINE

Summer Prince NECTARINE

Summergold PEACH

Summertime PEACH

Sundry PEACH

Supechsixteen PEACH

Superior BLUEBERRY

Superplantain PLANTAIN

Suplumthirtyeight PLUM-JAPANESE

Suplumthirtyone PLUM-JAPANESE

Suplumthirtyseven PLUM-JAPANESE

Suplumthirtysix PLUM-JAPANESE

Suziblue BLUEBERRY

Sweet Eve STRAWBERRY

Sweet Juana PEACH

Sweet Magic ${ }^{\text {TM }}$ GRAPE

Sweet Ring PEACH

Sweet Sunshine ${ }^{\mathrm{TM}}$ GRAPE

Sweet Surrender ${ }^{\mathrm{TM}}$ GRAPE

SweeTango $^{\circledR}$ APPLE

Tahoe Gold ${ }^{\circledR}$ CITRUS (ORANGE)

Tainung No. 17 PINEAPPLE

Tango MANGO

Tango CITRUS (ORANGE)

Tangor Norin No. 8 CITRUS (ORANGE)

TARS 1 CACAO

TARS 9 CACAO

TARS 14 CACAO

TARS 23 CACAO

TDE2 CITRUS (ORANGE)

TDE3 CITRUS (ORANGE)

TDE4 CITRUS (ORANGE)

Tecla STRAWBERRY

TH-682 BLUEBERRY

Treasure Harvest STRAWBERRY

TulaMagic $^{\circledR}$ RASPBERRY

UCB1 PISTACHIO

UCD GRN-1 ${ }^{\text {TM }}$ GRAPE ROOTSTOCK

UCD GRN-2 ${ }^{\text {TM }}$ GRAPE ROOTSTOCK

UCD GRN-3 ${ }^{\text {TM }}$ GRAPE ROOTSTOCK

UCD GRN-4 ${ }^{\text {TM }}$ GRAPE ROOTSTOCK

UCD GRN-5 ${ }^{\text {TM }}$ GRAPE ROOTSTOCK

UFRoyal NECTARINE

UFSharp PEACH

Ukee RASPBERRY

Unica STRAWBERRY

US Early Pride CITRUS (ORANGE)

US Seedless Pineapple CITRUS (ORANGE)

US-802 CITRUS ROOTSTOCK

US-812 CITRUS ROOTSTOCK

US-852 CITRUS ROOTSTOCK

US-897 CITRUS ROOTSTOCK

US-942 CITRUS ROOTSTOCK

Vale STRAWBERRY

Valentine CITRUS (GRAPEFRUIT/PUMMELO HYBRID)

Valley Red STRAWBERRY

Valor STRAWBERRY

Vermillion PITANGA

Vernia CITRUS (ORANGE)

Vinegold PEACH

Virgil PEACH

Vitória PINEAPPLE

Viva Patricia STRAWBERRY

Vulcan PEACH

VX211 PERSIAN WALNUT ROOTSTOCK

Wakefield RASPBERRY

Walden APPLE

Western Dawn APPLE

Western Princess PEACH

Westin CITRUS (ORANGE)

White Cloud PEACH 
White Diamond ${ }^{\circledR}$ PEACH

Wild Treasure BLACKBERRY

WineCrisp ${ }^{\mathrm{TM}}$ APPLE

Yellow Star Seedless CITRUS (LEMON)

Yellowsweet II PLUM-INTERSPECIFIC

Yellowsweet X PLUM-INTERSPECIFIC

Yosemite Gold ${ }^{\circledR}$ CITRUS (ORANGE)

ZARI APPLE

Zeta STRAWBERRY

Zill Dark PITANGA

\section{ADDENDA}

\section{BLACKBERRRY}

Natchez. USPP 20,891; 30 Mar. 2010 (List 44).

\section{GRAPE}

Marquette. USPP19,579; 16 Dec. 2008 (List 43).

\section{PEACH}

Flordabest. USPP 20,294; 15 Sept. 2009 (List 44). Gulfcrimson. USPP 20,174; 7 July 2009 (List 44).
PLUM

Autumn Yummy ${ }^{\circledR}$ registered trademark added (List 42).

Flavor Fall misspelled as Flavorfall (List 41).

Red Sun ${ }^{\mathrm{TM}}$. See 315-80-67 (List 41).

Yummy ${ }^{\circledR}$ beaut registered trademark added (List 42).

Yummy ${ }^{\circledR}$ giant registered trademark added (List 42).

Yummy ${ }^{\circledR}$ rosa registered trademark added (List 42).

\section{RASPBERRY}

Cascade Delight red raspberry. USPP 14,522. 10 Feb. 2004 (List 42).

Emily red raspberry. USPP 12,350. 15 Jan. 2002. (List 41).

Georgia red raspberry. USPP 19,438. 11 Nov. 2008. (List 43).

Josephine red raspberry. USPP 12,173. 30 Oct. 2001. (List 41).

Nanoose red raspberry. Parent BC $86-41-15$ is $3^{\text {rd }}$ generation Rubus strigosus not $4^{\text {th }}$. (List 44).

Nantahala red raspberry. USPP 20,689. 26 Jan. 2010 (List 44).

\section{STRAWBERRY}

PS-5096. USPP 20,291; 15 Dec. 2009 (List 44).

Clé des Champs. Mis-named La Clé des Champs (List 42).

Bliss. See PS-5298; USPP 19,583; 23 Dec. 2008 (List 44). 